Invited paper

\title{
The origins of Amazonian landscapes: Plant cultivation, domestication and the spread of food production in tropical South America
}

\author{
Jose Iriarte ${ }^{\text {a, }}{ }^{*}$, Sarah Elliott ${ }^{\mathrm{b}}$, S. Yoshi Maezumi ${ }^{\mathrm{c}}$, Daiana Alves ${ }^{\mathrm{d}}$, Regina Gonda ${ }^{\mathrm{a}}$, \\ Mark Robinson ${ }^{a}$, Jonas Gregorio de Souza ${ }^{e}$, Jennifer Watling ${ }^{\mathrm{f}}$, Josephine Handley ${ }^{\mathrm{g}}$ \\ a Department of Archaeology, College of Humanities, University of Exeter, Laver Building, North Park Rd, Exeter, EX4 4QE, UK \\ ${ }^{\mathrm{b}}$ Department of Archaeology and Anthropology, Bournemouth University, Fern Barrow, Poole, Dorset, BH12 5BB, UK \\ ${ }^{\mathrm{c}}$ Ecosystem and Landscape Dynamics, Institute for Biodiversity and Ecosystem Dynamics, University of Amsterdam, Science Park 904, Postbus 94240, 1090, \\ Amsterdam, the Netherlands \\ d Department of Anthropology, Federal University of Pará, Guamá Campus, R. Augusto Corrêa, 01, Belém, PA, 66075-110, Brazil \\ e Culture and Socio-Ecological Dynamics, Universitat Pompeu Fabra, Edifici Mercè Rodoreda C/ Ramon Trias Fargas, 25-27 08005, Barcelona, Spain \\ ${ }^{\mathrm{f}}$ Museum of Archaeology and Ethnology, University of São Paulo, Av. Prof. Almeida Prado 1466, Cidade Universitária, São Paulo, SP, 05508-070, Brazil \\ ${ }^{g}$ Department of Archaeology, University of Reading, Earley, Reading, RG6 6AX, UK
}

\section{A R T I C L E I N F O}

\section{Article history:}

Received 1 July 2020

Received in revised form

4 September 2020

Accepted 5 September 2020

Available online xxx

\section{Keywords:}

Amazon

Pre-columbian

Plant domestication

Agriculture

Food production

Land use

Amazonian dark earths

Pollen

Phytoliths

Charcoal

\begin{abstract}
A B S T R A C T
During the last two decades, new archaeological projects which systematically integrate a variety of plant recovery techniques, along with palaeoecology, palaeoclimate, soil science and floristic inventories, have started to transform our understanding of plant exploitation, cultivation and domestication in tropical South America. Archaeobotanical studies are providing a far greater appreciation of the role of plants in the diets of early colonists. Since $\sim 13 \mathrm{ka}$, these diets relied mainly on palm, tree fruits, and underground tubers, along with terrestrial and riverine faunal resources. Recent evidence indicates two areas of precocious plant cultivation and domestication: the sub-Andean montane forest of NW South America and the shrub savannahs and seasonal forests of SW Amazonia. In the latter area, thousands of anthropic keystone structures represented by forest islands show a significant human footprint in Amazonia from the start of the Holocene. While radiocarbon date databases show a decline in population during the middle Holocene, important developments happened during this epoch, including the domestication of cacao, the adoption of maize and the spread of manioc across the basin. The late Holocene witnessed the domestication of rice and the development of agricultural landscapes characterised by raised fields and Amazonian Dark Earths (ADEs). Our multi-proxy analysis of 23 late Holocene ADEs and two lakes from southern Amazonia provides the first direct evidence of field polyculture agriculture including the cultivation of maize, manioc, sweet potato, squash, arrowroot and leren within closed-canopy forest, as well as enrichment with palms, limited clearing for crop cultivation, and low-severity fire management. Collectively, the evidence shows that during the late Holocene Amazonian farmers engaged in intensive agriculture marked by the cultivation of both annual and perennial crops relying on organic amendments requiring soil preparation and maintenance. Our study has broader implications for sustainable Amazonian futures.
\end{abstract}

(C) 2020 Elsevier Ltd. All rights reserved.

\footnotetext{
* Corresponding author.

E-mail addresses: J.Iriarte@exeter.ac.uk (J. Iriarte), selliott@bournemouth.ac.uk (S. Elliott), s.y.maezumi@uva.nl (S.Y. Maezumi), daianatalves@gmail.com (D. Alves), regina.gonda@gmail.com (R. Gonda), m.robinson2@exeter.ac.uk (M. Robinson), jonas.gregorio@upf.edu (J. Gregorio de Souza), jwatling@usp.br (J. Watling), j.n.handley@pgr.reading.ac.uk (J. Handley).
}

\section{Introduction}

Carrying out a synthesis of plant domestication and the development of agriculture in Amazonia is a challenging enterprise given its spatial scale, the heterogeneous nature of its ecosystems, its temporal depth, the variety of pre-Columbian land use systems, and the rapid pace of new archaeological, archaeobotanical, palaeoecological, and palaeoclimatic findings over the last decade. Our synthesis has a broader focus on tropical South America (SA), 
but concentrates on recent developments in Greater Amazonia including Venezuela and the tropical forests of Colombia (hereafter called Amazonia). The Amazon basin alone is roughly the size of continental U.S. $\left(7,000,000 \mathrm{~km}^{2}\right)$ and vast expanses of its forests are still archaeologically unexplored (e.g., de Souza et al., 2018; FrancoMoraes et al., 2019; Gonda, 2018). Amazonian landscapes are heterogeneous, encompassing seasonal, humid and flooded forests along with wetlands and savannahs. They have a long history of human occupation starting at least $\sim 13 \mathrm{ka}$ (calibrated years before the present) (Magalhães et al., 2019; Morcote-Ríos et al., 2020; Roosevelt et al., 1996; Shock and Moraes, 2019). All these factors have combined to produce a remarkable number of distinct language families and one of the most ethnically diverse regions of the planet (Fig. 1) (Epps and Salanova, 2013; Moran, 1993; Nichols, 1992). The Amazon is home to 350 ethnic groups and protected indigenous lands occupy $\sim 4 \mathrm{~m}$ square kilometres.

In the last thirty years, archaeology has revealed sizable, regionally organised, complex societies across Amazonia (e.g., de Souza et al., 2019a; Heckenberger and Neves, 2009; Prümers and Jaimes Betancourt, 2014; Roosevelt, 2013; Rostain and Jaimes Bentancourt, 2017). These differ markedly from the small-scale societies described by anthropologists in the twentieth century. The new picture revealed by archaeology accords with the first eyewitness chronicles from the sixteenth to seventeenth centuries (e.g, Medina, 1934; Myers, 1974; Porro, 1996). These early historical accounts of journeys along the major Amazonian rivers describe numerous complex, sedentary societies, which were part of extensive political territories engaged in large-scale organised warfare. Some polities occupied large continuous tracts of the
Amazon River over dozens of kilometres with population ranging from 800 to 3000 people, with some settlements as large as 10,000 (Denevan, 1996). Several sources suggest that these 'provinces' were socially stratified units in which a centralised power ruled over several local groups. Such hierarchies comprised regional and local chiefs, nobles, commoners, and subordinate individuals including servants and captive slaves (see summaries in Porro, 1994; Roosevelt, 1987a). The initial European eyewitness accounts also describe how these riparian complex societies extended throughout the mainland through elaborated road systems (Eder [1772] 1985; Medina, 1934; Pires de Campos, 1862), exhibiting large populations organised as interconnected polities where villages over 1000 were not uncommon (Denevan, 1996). The accounts are being corroborated by new archaeological research (de Souza et al., 2018; Heckenberger, 2005; Iriarte et al., 2020; Paz-Rivera and Putz, 2009; Stenborg et al., 2012). Some interfluvial areas may well have been examples of low-density urbanism similar to that found in other tropical regions (Heckenberger et al., 2008).

In contrast to present Amazonian indigenous groups, who practise predominantly shifting cultivation (swidden) with periods of short cropping and long fallow, using metal axes, early chronicles describe intensive food production systems of both seed and root crops, prominently manioc (Manihot esculenta) and maize (Zea mays) in mono and polycultural fields, along with hunting, fishing and long-term food storage. Ethnobotanical works provide an idea of the number and variety of annual and perennial crops cultivated by indigenous Amazonian people (see summary in Cunha, 2019). Some groups, such as the Amuesha of Peru, plant up to 204 varieties of manioc (Emperaire, 2001; Salick et al., 1997) while dozens of

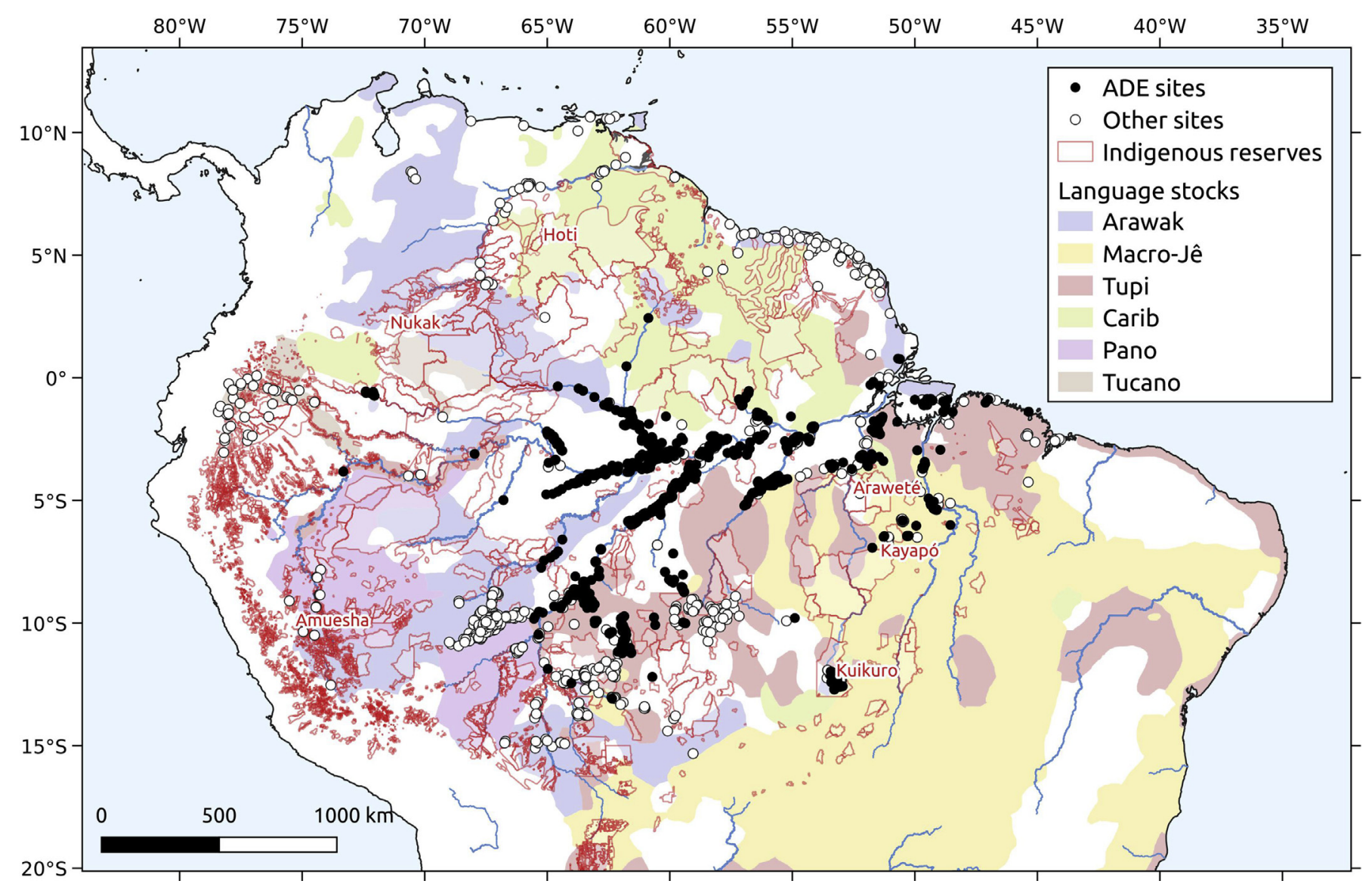

Fig. 1. Map of tropical South America showing language stocks (Campbell, 1997), indigenous territories (RAISG ,2019) and groups mentioned in the text. 
varieties of maize have been recorded by Brieger et al. (1958) in lowland SA. Since annual crops disappear after human abandonment (Clement, 1999a, b), a larger number of varieties surely existed before the decimation of indigenous populations following the 1492 Columbian Encounter (CE). The management of tree and palm fruits and nuts is also a significant part of Amazonian traditional economies. Sixty eight percent of the 138 species of domesticated food crops cultivated by Amazonian peoples at the time of first European contact documented by Clement (1999b) are perennial and woody crops, the majority of which are tree fruits and nuts. Most of these are native species, but also include many species from other parts of SA and Mesoamerica.

Progress in Amazonian archaeology and ethnobotany has been accompanied by recent developments in archaeobotany, palaeoecology and molecular biology, confirming Amazonia as an independent centre of plant domestication. Amazonia is the cradle of origin of important crops consumed both locally and worldwide. These include manioc, sweet potato (Ipomoea batatas), yam (Dioscorea trifida), cocoyam (Xanthosoma sagittifolium), peach palm (Bactris gasipaes), chili peppers (Capsicum spp.) including murupi pepper (Capsicum chinense), squash (Cucurbita spp.), pineapple (Ananas comosus), papaya (Carica papaya), peanut (Arachis hypogea), cashew (Anacardium occidentale), guava (Psidium guajava), biribiri (Averrhoa bilimbi), tobacco (Nicotiana tabacum), annatto (Bixa orellana), bacuri (Platonia insignis), cupuaçu (Theobroma grandiflorum), mapati (Pourouma cecropiifolia) and cubiu (Solanum sessiliflorum) (Clement, 1999b; Clement et al., 2016; Iriarte, 2007; Piperno and Pearsall, 1998; Shepard et al., 2020). New data shows that cacao (Theobroma cacao), a tree native to SA, long thought to be domesticated in Mesoamerica, is likely to have been domesticated in Ecuador (Zarrillo et al., 2018). Hilbert et al. (2017) have recently documented the third global event of rice domestication (Oryza sp.) in the wetlands of the Guaporé River in south-western (SW) Amazonia. This region is also emerging as the potential locale for duck (Carina moschata) domestication (von den Driesch and Hutterer, 2011). In addition it is becoming clear that some of the earliest ceramics in the New World began to be manufactured in Amazonia starting 7ka (Oyuela-Caycedo and Bonzani, 2005; Pugliese et al., 2018; Roosevelt et al., 1991).

In this paper, we review recent developments in the study of plant cultivation, domestication and the spread of food-production systems in Amazonia. We follow the periodisation proposal of Walker et al. (2018) for the chronological subdivision of the Holocene. We start with a brief examination of some conceptual definitions and the particularities of food-production in Amazonia, followed by a short review of current methodologies for studying plant domestication and the development of agriculture. Next, we summarise our knowledge of early plant consumption during initial colonisation of South America and the beginnings of plant cultivation and domestication during the late Pleistocene-early Holocene transition, followed by evidence for the middle Holocene and late Holocene when pre-Columbian Amazonian peoples began to transform the landscape at a scale not seen before, through the creation of raised field agricultural landscapes and the spread of Amazonian anthrosols (Amazonian Dark Earths or ADEs). The remainder of the paper concentrates on ADEs. Although major advances have been made to understand the archaeology, genesis, geochemistry, and flora growing today on ADEs, until now there has been little data about the land use systems they supported. We fill this gap with the analysis of 23 terrestrial phytolith and charcoal records and two lake pollen-charcoal records from across Amazonia, derived mainly from our ERC Pre-Columbian Amazon-Scale Transformations (PAST) project on land use practices on Amazonian anthrosols during the late Holocene.

\section{Particularities of Amazonian food-production: a word on definitions}

As reviewed by Denham and Vrydaghs (2007), there is continued debate about what constitutes agriculture and its archaeological/palaeoecological connections (e.g., Harris, 1977; Smith, 2001; Terrell et al., 2003). The need to study agriculture 'on its own terms' in different parts of the world has long been recognised (Harris, 1977). Researchers working in non-Eurasian regions, particularly the tropics, have become increasingly aware of the fundamental differences in the nature of agriculture and the methods we should employ for its study. These issues have been reaffirmed for the neotropics by the seminal works of Piperno and Pearsall (1998) and Clement (1999b). However, a tendency has persisted to evaluate agriculture across the globe using concepts, lines of evidence, and methods derived from Eurasian research. The contributors to Rethinking Agriculture (Denham et al., 2007), highlighted the differences in the nature of plant domestication and spread of agriculture in tropical regions of the world against the Eurasian perspectives characterised by clear morphogenetic changes in plants or animals, environmental transformations resulting in forest clearance for agriculture, and packages of associated cultural, political and social traits (see also Denham et al., 2003; Whitehouse and Kirleis, 2014). The fact that Eurasian processes of 'becoming agricultural' and the definition of agriculture itself are not necessarily transferable to Amazonia has been restated in different works since then (Arroyo-Kalin, 2010; Cunha, 2019; Fausto and Neves, 2018; Moraes, 2015; Neves, 2007, 2013; Neves and Heckenberger, 2019; Oliver, 2008; Shepard et al., 2020).

Plant domestication and agriculture in SA show distinct aspects which differentiate them from Eurasian contexts. Similar to the picture emerging in New Guinea and Africa (Denham, 2018; Denham and Vrydaghs, 2007), the available data suggest that the domestication of plants in the neotropics was characterised by more diffuse spatial patterns than in Eurasian regions. Endorsing previous views (Bray, 2000; Harlan, 1995; Piperno and Pearsall, 1998), current archaeological, genetic and biogeographical evidence shows that there was no single centre of domestication or agricultural origin in the Americas. On the contrary, independent origins in Central and SA are now apparent, while multiple origins within lowland SA are likely (Clement et al., 2015; Piperno, 2011). The available data from the neotropics suggest a mosaic-like pattern of domestication, diffuse in space, with multiple areas of early, independent agricultural innovation involving different plants. It is also becoming clear that crop plants in the same genus, such as Cucurbita squashes, were sometimes concurrently brought under domestication in several different regions, such as highland Mexico (Smith, 1997), tropical southern Mexico (Sanjur et al., 2002), southwestern Ecuador (Piperno and Stothert, 2003), and possibly the Llanos de Mojos (Lombardo et al., 2020), among other potential areas (see Sanjur et al., 2002).

In addition, unlike Eurasian agriculture, which was traditionally focused on relatively few cereals, a number of different plants are known to have been brought under domestication in the Americas, including a variety of root crops (e.g., manioc, sweet potato, yams), beans and pulses, squashes, vegetables, tree crops and condiments. Some of them, such as the majority of palms, do not show morphogenetic changes even under intensive management. The lowland South American crop plant complex (Pearsall, 2008) contains a large and diverse assemblage of tree-fruits, nuts and palms, and includes only two demonstrably domesticated grass grains: maize and rice (Oryza sp.) (Hilbert et al., 2017). Of the 83 crops native to Amazonia and adjacent areas inventoried by Clement (1999a), 68\% are trees and woody perennials with some degree of domestication. Along with these plants that show some evidence of 
domestication, there are an estimated 3000-5000 exploited nondomesticated plant species (Borem et al., 2012).

In this paper, we do not create new analytical categories nor exclude the concept of agriculture altogether. Since plant domestication, as argued by Harris and Hillman (1989), is a continuum of human investment in selection and environmental manipulation, any definitions are constructs that imperfectly reflect the real world. In this review, we concentrate on practices that can be documented in the archaeological and palaeoecological record and follow the simple definitions. We loosely refer to horticulture as small-scale plantings in residential home gardens that typically contain a range of plants, from morphologically wild to clearly domesticated. The defining step into agriculture is the presence of fields, dedicated to the long-term cultivation of plots in and around larger and more permanent settlements. In some areas of tropical $\mathrm{SA}$, it is this defining moment, when people invest in long-term physical and chemical improvements to the soil to intensify cultivation and productivity at particular sites, that marks the beginning of agriculture (see below).

\section{Sources of evidence and methodologies}

During the last three decades, a combination of new archaeological/archaeobotanical projects in previously unexplored regions, the use of molecular data, the systematic application of microfossil botanical techniques, and associated palaeoecological research pioneered in the neotropics by Pearsall $(1995,2016)$ and Piperno (1988, 2006) has radically changed our understanding of the timing, geographical origins, and diversity of food-producing systems in the neotropics (e.g., Carson et al., 2014; Iriarte et al., 2004; Iriarte et al., 2012; Kistler et al., 2018; Maezumi et al., 2018; Piperno et al., 2009; Robinson et al., 2018; Watling et al., 2017; Whitney et al., 2013). We cannot hope to cover all the methodologies and proxies used to study plant domestication and the development of agriculture in lowland SA (see also Mayle and Iriarte, 2014; Montoya et al., 2020; Whitney and Cárdenas, 2017). Here we highlight only the most recent and pertinent methodologies, noting the advantages and limitations of each. We refer the reader to Montoya et al. (2020) for a summary of geomorphology.

\subsection{Archaeobotany}

The study of the plant component of pre-Columbian subsistence and economy in Amazonia is at an early stage. Until recently, only a few projects systematically applied archaeobotanical recovery techniques and there is thus a paucity of primary data. However, progress has been swift in the last decade. Reference collections of macro- (e.g., Bruno, 2010; Morcote-Ríos and Bernal, 2001; Silva et al., 2013) and micro-botanical remains (e.g., Morcote-Ríos et al., 2015; Watling et al., 2020a; Watling and Iriarte, 2013) are being constructed, and the recovery of plant remains is becoming more systematic in archaeological excavations.

Starch grains and phytoliths are proving effective in documenting root and tuber crops. Many tuber crops (e.g., sweet potato and yams) do not produce diagnostic phytoliths, but do produce diagnostic starch grains that can be recovered from plant processing tool residues or ceramic containers (e.g., Corteletti et al., 2015; Dickau et al., 2007; Ezell et al., 2006; Pearsall et al., 2004; Piperno et al., 2009; Piperno et al., 2000). Phytoliths survive well in tropical soils and are deposited in situ. They are thus useful for documenting crop cultivation in agricultural landscapes, such as raised fields (e.g., Iriarte et al., 2012; Whitney et al., 2014), and provide the first direct evidence of cultivation on Amazonian anthrosols. Ongoing refinement in the identification of the micro- morphological features of phytoliths and their three-dimensional morphology, together with the application of multivariate statistical analysis, is allowing archaeobotanists to distinguish phytolith morphotypes to a greater taxonomic resolution. For example, the identification of phytolith micro-morphological features of the palm family Arecaceae is allowing the distinction of some palm phytoliths to the genus level, such as Geonoma (conical variant with basal projections) and Euterpe (large symmetric globular echinates with short bold projections) (Dickau et al., 2013; Huisman et al., 2018; Morcote-Ríos et al., 2016). These advances apply not only to individual plants, but also to differentiating neotropical ecosystems through their soil phytolith assemblages (Dickau et al., 2013; Watling et al., 2016). Macro-remains of palms and tree fruits and nuts, such as Brazil nut and pequi (Caryocar sp.) are now beginning to be systematically recovered from archaeological sites where flotation is employed (e.g., Neves et al., 2016; Shock et al., 2014; Watling et al., 2018). The combination of macro and microbotanical analyses allows for more complete plant consumption inventories (Dickau et al., 2012; Watling et al., 2018). Anthracology (charcoal analysis) has also provided new insights into landscape and cultural practices. For example, at the Hatahara site of pre-ADE context $(\sim 2.2-1.5 \mathrm{ka})$ and ADE Paredão phase $(\sim 1.2-0.7 \mathrm{ka})$ in the central Amazon, a predominance of early successional stage taxa (e.g., Melastomataceae) has been identified, indicating that the collection of firewood took place in secondary forest vegetation surrounding settlements, but also in fallows (Scheel-Ybert et al., 2016). The plant taxa identified using charcoal also suggest practices of succession management, resource use, and the creation of areas of secondary vegetation around the settlement since $\sim 2.2 \mathrm{ka}$ at the Hatahara site. Despite recent advances in the taxonomic resolution of some crops, we should bear in mind that many indigenous plant foods used by pre-Columbian Amazonian people, including large numbers of perennial tree crops, will be invisible in the fragmentary archaeobotanical record.

\subsection{Palaeoecology}

Like archaeobotany, neotropical palaeoecology is a rather young discipline that began in the late 1960s with a primary emphasis on the reconstruction of natural vegetation histories through pollen analysis of long-term sedimentary sequences (e.g., lake and bog cores), focusing on glacial cycles (Colinvaux, 2008). More recently, palaeoecology has devoted more attention to human-environment interactions, considerably transforming our understanding of the environments and flora associations in which plant domestication and the development of agriculture took place. These efforts have been facilitated by the creation of a searchable neotropical pollen database (Bush and Weng, 2007) and the consolidation of a Latin American Pollen Database (Flantua et al., 2015a). Palaeoecology, which typically provides continuous, uninterrupted time series, spanning sub-centennial to multi-millennial vegetation records, offers the longer temporal perspective to complement ethnobotany, floristic studies and ecology. The long-term nature of palaeoecological records can help resolve long-standing controversies about the past human footprint on modern vegetation formations. It is only by comparing palaeo records with modern floristic inventories that we can help disentangle recent from preColombian influences in the flora. For example, it has been proposed that many palm forests of Amazonia are the result of recent historical land use (McMichael et al., 2017; Heijink et al., 2019), but although historical land uses dramatically changed landscapes, and cannot be ignored, numerous palaeoecological records show that increases in plants of economic importance began during preColumbian times. Examples are the increase in palms detected 
when human activities intensified during the late Holocene, in the 'Geoglyph' region of Acre (Watling et al., 2017) and along the Gran Sabana (Rull and Montoya, 2014), and the increase in Attalea palms $\sim 1.5 \mathrm{ka}$ in the Versalles lake (Maezumi et al. in prep). Since in many cases palaeoecological records pre-date human occupation, they can also provide ecological baselines with which to compare preand post-human impacts on the environment.

The close integration of on-site archaeological data with off-site palaeoecological and paleoclimate records is producing novel insights into understanding land use systems in Amazonia (e.g., Carson et al., 2014; Castilla-Beltrán et al., 2018; Iriarte et al., 2012; Maezumi et al., 2018; Robinson et al., 2018; Whitney et al., 2013). Soil-depth phytolith and stable carbon isotope transects provide an alternative method for reconstructing regional vegetation and fire histories in the absence of lakes (de Freitas et al., 2001; McMichael et al., 2012; Piperno and Becker, 1996; Watling et al., 2017). The complementarity of phytolith and pollen analyses has proved particularly useful, in terms of both taxonomic resolution and spatial scale. While phytoliths have higher taxonomic resolution beyond the family level for many grasses and herbs, pollen analysis exhibits better taxonomic resolution for woody taxa. Similarly, lake pollen records can capture regional signals $\left(>10 \mathrm{~m}^{\wedge} 2\right)$ while the phytoliths from soil-depth profiles provide local spatial scale $\left(<1 \mathrm{~m}^{\wedge} 2\right)$. The utilisation of these proxies in tandem therefore provides greater floristic detail and spatial resolution than either proxy alone (e.g., Carson et al., 2015; Castilla-Beltrán et al., 2018; Iriarte et al., 2004; Neff et al., 2006; Piperno and Jones, 2003; Piperno et al., 2007). Furthermore, combining the more localised proxies with pollen data has been effective in distinguishing between human and natural climate contributions to broad vegetation change (Robinson et al., 2018).

A simple technique for recovering large, heavy crop pollen (Whitney et al., 2012) has substantially increased the diversity and volume of crop pollen recovered from lake records. In turn this has supported the growing recognition that identifying increases and decreases in maize and charcoal in pollen records is not the only or necessarily the best measure of plant cultivation in pre-Columbian Amazonia (Iriarte et al., 2012; Maezumi et al., 2018; Whitney et al., 2014) and other parts of the neotropics (McNeil et al., 2010). Pollen taxonomic resolution of important ecological taxa is developing (e.g., Burn and Mayle, 2008). Palms have been increasingly detected in pollen records, for example. An increase in Mauritia/Mauritiella palm pollen has been argued as evidence of more intensive land use (Rull and Montoya, 2014), while the decrease or disappearance of other palms such as Iriartea deltoidea, used as construction materials, have evidenced more intensive land use (Bush and McMichael, 2016). Still, some important pollen taxa, such as Theobroma cacao, which has a highly specialised pollination mechanism (Ceratopogonidae midges), are difficult to detect in the pollen sedimentary records even with extended counting (Carson et al., 2016). The employment of environmental ancient DNA from sediment cores can be a complementary tool to pollen for establishing the composition of both terrestrial and aquatic local plant communities (see Pedersen et al., 2013, 2015) is a future challenge for the tropics. Finally, improved statistical methods including Bayesian age-depth modelling is providing more precise chronologies to document plant domestication and environmental histories (Blaauw and Christen, 2013).

\subsection{Molecular research}

Molecular research is another resource for researchers in the Americas and elsewhere who seek to understand crop plant domestication (Clement et al., 2010; Pickersgill, 2007; Sanjur et al.,
2002). Molecular data are helping to fingerprint the wild progenitors of domesticated plants and pinpoint their present-day and, by inference, ancient geographical distributions. Molecular data have informed us that some crops were probably domesticated only once, including maize (Doebley, 1990; Matsuoka et al., 2002), manioc (Olsen and Schaal, 1999, 2001), potatoes (Solanum tuberosum) (Spooner et al., 2005), cotton (Westengen et al., 2005) and sweet potato (Muñoz-Rodríguez et al., 2018). Other major crop plants were probably domesticated more than once, in different regions of the Americas. They include squash species such as Cucurbita pepo (Sanjur et al., 2002), common beans (Phaseolus vulgaris) (Sonnante et al., 1994) and sunflower (Helianthus annuus) (Harter et al., 2004). Some important root crops such as arrowroot, cocoyam, and sagu have not been studied yet, while research into others, such as Ipomoea, is progressing. Recent genetic work by Muñoz-Rodríguez et al. (2018) suggests that sweet potato likely diverged from its closest wild relative, I. trifida, over 1 million years ago. The results of their study indicate that sweet potato evolved long before the onset of human agriculture, and that the storage root was an existing trait present before the arrival of humans to the continent, which likely favoured the uptake of this species into human cultivation systems. Modern genetic information can also provide us with 'molecular clocks' that can point to the relative timing of plant domestication (Matsuoka et al., 2002; Olsen and Schaal, 2001). Genetic analysis is also revealing the particular loci responsible for domesticated traits in plants, such as the lignification of domesticated squash rinds (Piperno et al., 2002) or the branching architecture of maize tassel and ear (Sigmon and Vollbrecht, 2010).

Establishing the phenotypic and genetic characterisation of these ancient and modern Amazonian plants as they changed from wild to domesticated is a massive task. This is particularly so for the large number of Amazonian tree crops, whose initial classification into domestication categories, based on the works of Balée (1989), Cavalcante (1991), Frikel (1978) and Lévi-Strauss (1952), has admittedly been subjective. However, progress continues to be made. Moreira et al. (2015) show the selection of annato (Bixa orellana) for increased pigment yields and fruit dehiscence. The analysis of pequi (Caryocar brasiliensis) varieties among the Kuikuro of the Upper Xingu by Smith and Fausto (2016) shows selection for larger pulp thickness and absence of spines. Genetic biogeography is another powerful tool. Genetic studies on Brazil nut support a rapid and recent irradiation from an ancestral population of this species, which likely took place in northern/eastern Amazonia during the first millennium AD, based on the lack of sequence diversity and the absence of geographical structuring withinpopulation variability (Shepard and Ramirez, 2011; see also Thomas et al., 2015).

\subsection{Isotopic research}

Stable carbon and nitrogen isotope analysis of bone collagen is a well-established approach for deriving dietary information from human and faunal remains (e.g., Ambrose and Norr, 1993) and has been employed to reconstruct pre-Columbian subsistence economies across much of SA (e.g., Hermenegildo et al., 2017; van der Merwe et al., 1981). This technique is at an early state in Amazonia. Contextual isotopic baselines for robust quantitative and qualitative reconstructions are being compiled for the neotropics, which is crucial given that freshwater fish and C3 plants may display similar $\delta^{13} \mathrm{C}$ values, and in some cases also $\delta^{15} \mathrm{~N}$ values depending on species and environments (e.g., Martinelli et al., 2007). Similarly, the majority of domesticated annual crops (manioc, sweet potato, yams, beans and peanuts, among others) 
have a C3 photosynthetic pathway and in general their stable carbon isotope composition $\left(\delta^{13} \mathrm{C}\right.$ values) cannot be differentiated from other wild or managed C3 plants. Consequently, obtaining bone collagen and apatite $\delta^{13} \mathrm{C}$ values consistent with $\mathrm{C} 3$ plants does not necessarily mean that people are relying on wild $\mathrm{C} 3$ plants for most of their diet. Conversely, the lack of a C4 signature that can only be produced by maize does not necessarily mean the lack of other $\mathrm{C} 3$ annual crops in pre-Columbian diets. However, carbon and nitrogen stable isotopes can provide us with a clear picture of the timing when maize became a staple crop. For example, a recent study from 52 radiocarbon-dated human remains from rock shelters in the Maya Mountains of Belize, spanning the last 10ka, has shed light on the role of maize in this region. The study shows no clear evidence for the consumption of maize before $\sim 4.7 \mathrm{ka}$. Evidence for substantial maize consumption ( $30 \%$ of total diet) appears in some individuals between $4.7-4.0 \mathrm{ka}$, while the isotopic evidence shows that maize became a staple ( $>70 \%$ of total diet) after 4 .0ka (Kennett et al., 2020).

\subsection{Palaeoclimate records}

The acquisition of new localised high-resolution climate records clearly demonstrates the heterogeneity of climate change across different regions of lowland SA. For example, records show antiphasing between SW Amazonia and NE Brazil (Deininger et al., 2019). Local palaeoclimate sequences are particularly useful in disentangling natural from human-induced changes in vegetation. The availability of these new palaeoclimate records is allowing us to carry out integrative studies using archaeological, palaeoecological and palaeoclimatological data to evaluate the relationship between climate change, distinct subsistence strategies and cultural transformations in Amazonia (de Souza et al., 2019a), thus uncoupling the climate from the human drivers in the expansion of Araucaria forest during the last millennium in SE Brazil (Robinson et al., 2018), as well as exploring the role of the drier middle Holocene climate (Riris and Arroyo-Kalin, 2019) and the wetter late Holocene. The wetter late Holocene climate that resulted in the expansion of forests created an ecological opportunity for Tupi forest farmers to spread out of Amazonia into SE SA during the late Holocene (Iriarte et al., 2017) (see also Riris and Arroyo-Kalin, 2019; Arroyo-Kalin and Riris, 2020).

\subsection{Ethnography, ethnobotany and historical accounts}

These disciplines have documented the heterogeneity and subtleties of traditional land use systems including agroforestry, flood-recessional agriculture, slash and burn, slash and mulch, and the cultivation of ADEs (see summary in Denevan, 2001; Levis et al., 2018). They have documented the diversity of annual crops and have revealed the importance of many non-domesticated (or not fully domesticated) plant species for lowland South American livelihoods today (e.g., Balée, 2013; Clement, 1999b). Modern ethnography has also revealed how the process of domestication in native Amazonian societies is linked to cosmological and ontological processes and the role of non-human agents (Fausto and Neves, 2018; Shepard et al., 2020). Knowing more about the ways in which indigenous epistemologies have guided indigenous domestication practice can certainly provide us with insights into the social processes that likely took place when Amazonian people began to domesticate and manage hundreds of plants during the last ten millennia (Rival and McKey, 2008).

Making extrapolations from modern ethnography to the past is not straightforward, since the $C E$ had a profound impact on Native American populations. Analysis of archaeological radiocarbon data shows that the CE had a heterogeneous impact across the basin (de Souza et al., 2019a), while estimates of population decimation range from $80 \%$ to $95 \%$ (see summaries in Nevle and Bird, 2008). Population decline had a massive impact on the agricultural labour force numbers and consequently on land use systems. Some agriculturalists became foragers (Balée, 1994; Fausto, 2001; LéviStrauss, 1952), while others likely changed from intensive cultivators to long-fallow shifting cultivation (Denevan, 2004). Furthermore, past land use systems may not have modern analogues with which to compare. Many land use systems, such as the vast expanses of raised fields and landscape-scale fish weirs in the Llanos de Mojos, were abandoned after the CE and local inhabitants have no social memory of them. Despite their scarcity, ambiguity, and potential exaggeration, the early chronicles represent one of our best chances of obtaining information about pre-Columbian land use systems. Many of the early chronicles of the Amazon formerly regarded as exaggerations and fantasies are now largely corroborated by archaeology.

\subsection{Floristic inventories}

Floristic inventories along with interviews have brought to light the variety of crops in home gardens, nearby swiddens and managed forests. Work on ADEs has been particularly productive, showing that (i) forests on today's ADEs have a distinct species composition, exhibiting greater richness and a higher abundance of domesticated and edible plants (used as food resources) including many indicator species (Almeida de Oliveira et al., 2020; Clement, 2003; Clement et al., 2004; Guix, 2005; Junqueira et al., 2011; Levis et al., 2012; Odonne et al., 2019; Quintero-Vallejo et al., 2015), (ii) the more complex the ADE archaeological context (for example, multicomponent sites), the greater the floristic composition of cultivated useful plants in modern home gardens (Lins et al., 2015), and (iii) increased fertility associated with ADEs improves conditions for the establishment and growth of exotic species that are generally more nutrient-demanding than native Amazonian species (de Souza et al., 2019b). These local floristic inventories and basin-wide analyses suggest that modern tree communities in Amazonia are structured to a significant extent by a long history of plant domestication by Amazonian peoples. Levis et al. (2017), using 1170 forest plots of the Amazon Tree Diversity Network, overlaid known archaeological sites in Amazonia with the distributions and abundances of 85 woody species domesticated by preColumbian peoples. They found that the relative abundance and richness of domesticated species increased in forests on and around archaeological sites, and that domesticated species were five times more likely than non-domesticated species to be hyperdominant (Ter Steege et al., 2013, 2020).

\subsection{An integrative methodology}

In order to understand pre-Columbian land uses, their environmental impacts, and their modern legacy we have designed a multi-disciplinary approach tied to careful site selection. To overcome the limitations of utilising singular proxies we employed multiple archaeobotanical and palaeoecological methodologies on different spatial scales by integrating both on-site and off-site proxies. We integrated archaeological on-site phytolith and micro-charcoal data with palaeoecological and paleoclimate offsite pollen, charcoal and speleothem records to obtain continuous, uninterrupted multi-millennial vegetation and climate baselines at a regional level, in addition to in situ direct evidence of cultivation at a local scale. Our approach combined the best available taxonomic resolution and spatial scale, resulting in greater 




Fig. 2. Schematic diagram of the integration of the multiple techniques.

floristic detail and spatial resolution. The wider use of microscopic archaeobotanical remains revealed many plants that are often silent in the macro-botanical record and vice versa. Furthermore, unlike most studies that concentrate on either the fossil record (archaeology/palaeoecology) or the modern record (floristic inventories/ethnobotany), we compared the fossil archaeological, archaeobotanical, palaeoecological and palaeoclimate records with modern floristic inventories to properly assess the modern legacy of past land use in today's forests while embracing the full breadth of Amazonian scholarship (Fig. 2).

\section{History of plant domestication and the development of agricultural systems}

\subsection{Late Pleistocene/early Holocene (late Pleistocene-8.2ka): colonisation, plant cultivation and domestication}

\subsubsection{Timing, climate and environments of earliest tropical South America settlers}

The suitability of tropical forests for long-term navigation, subsistence and occupation during human dispersals is a matter of lively debate (Barton et al., 2012; Cosgrove et al., 2007; Mercader, 2002; Sillitoe, 2002). Research over the last two decades has highlighted the use of tropical rainforests by human foragers, including the manipulation of tree products, management of forest composition, anthropogenic burning, cultivation of edible plants, the detoxification of particular plants, and the hunting of medium to small-sized arboreal, semi-arboreal, and terrestrial tropical game (see summary in Roberts, 2019). Evidence suggests that the human manipulation of forest ecosystems began in SE Asia at least 50-45ka (Barker et al., 2017) and in Melanesia from 45ka (Summerhayes et al., 2017). In the Americas, the early colonists have traditionally been portrayed as highly specialised mobile hunter-gatherers exploiting coastal resources and big savannah game, whilst avoiding forest habitats due to the absence of large mammals and the difficulties of movement (Lothrop, 1961; Lynch, 1990; Sauer, 1944).
However, mounting evidence shows that these early South Americans did not avoid tropical rainforests, nor were they passive consumers of its resources. The evidence hints at early cultivation of annual crops and the management of trees of economic importance (Aceituno and Loaiza, 2018; Iriarte, 2007; Lombardo et al., 2020; Morcote-Ríos et al., 2014; Piperno, 2011; Roosevelt et al., 1996; Shock and Moraes, 2019), with implications for understanding plant domestication, the long-term legacy of human-plant interaction, and the potential role of humans in the current hyperdominance of useful plants in Amazonia (Levis et al., 2017).

The peopling of lowland SA took place amidst one of the most significant climatic, environmental and subsistence regime shifts in human history, a shift which led to the extinction of megafauna, plant domestication, and today's remarkable diversity among South American indigenous groups (Moran, 1993; Nichols, 1992). Current archaeological and genomic data suggest that the Americas were colonised sometime between $\sim 25$ and $15 \mathrm{ka}$ by anatomically modern humans who likely followed a Pacific Rim corridor from northeast Asia into the New World, reaching southern Chile by at least 14.3ka (Braje et al., 2017; Dillehay, 2017; Pedersen et al., 2016). The groups that colonised the Amazon Basin were foragers who journeyed into NW SA via the Darien Gap and/or the Caribbean littoral (Ranere et al., 2002). Earliest dated occupation comes from Monte Alegre in eastern Amazonia 13.1 ka (Roosevelt et al., 1996). In contrast to North American early settlers, many of which exhibit bifacial technologies associated with 'big-game hunting', most early sites in tropical South America exhibit expedient unifacial technologies associated with broad-spectrum economies, where plants likely played a major role (Aceituno and Rojas-Mora, 2015; Dillehay and Rossen, 2002; Kipnis, 1998). Many early sites, such as Taima-Taima (Bryan et al., 1978), Paiján (Chauchat, 1975; Maggard, 2015), sites in the Middle Magdalena River (Ranere and López, 2007), and Monte Alegre (Roosevelt et al., 1996) concurrently used unifacial, bifacial, and flake tools in association with a variety of ground stones (manos, grinding stones, axes, waisted hoes) attesting to the diversity of their subsistence economies. 
Collectively, these sites showcase the variety of adaptations to the diverse array of environments the early settlers encountered.

These early colonists encountered a very different climate. In general, late Pleistocene temperatures in Amazonia were cooler by as much as $5{ }^{\circ} \mathrm{C}$ (Colinvaux et al., 1996), with precipitation reduced by $30-50 \%$, compared to late Holocene conditions (Piperno, 2011). The Holocene began with temperatures and rainfall levels roughly similar to today's levels, steadily increasing in warmth and humidity until reaching a long-term optimum beginning around 10.5ka. Depending on the area and elevation late Pleistocene climate conditions resulted in (i) the replacement of much of the seasonal tropical forest by types of open vegetation similar to today's thorn woodlands, thorn scrublands, and savannahs, (ii) partial replacement and reduction of lowland evergreen rainforest by arboreal elements that are now primarily confined to drier types of forest and montane environments (e.g., Podocarpus, Alnus, Myrsine), and (iii) an 800-1200 m downward slope movement of some forest elements that today are generally restricted to cool and high mountainous areas above $1500 \mathrm{~m}$ (Piperno, 2011). Recent studies suggest that even the driest regions of Amazonia, the so-called 'dry corridor', where precipitation fell $\sim 42 \%$, were likely not savannahs but dry-forest habitats with low temperatures that reduced evaporation rates (Bush, 2017; Wang et al., 2017). This suggests that the large tracts of the northern rim of the Amazon proposed by Piperno and Pearsall (1998) as savannahs were likely seasonal forests, and raises the possibility that early settlers colonised and adapted not to open savannahs but to seasonal forests. Late Pleistocene palaeoecological records are much needed in this region to resolve this important matter.

These early settlers of tropical SA also confronted a very different fauna that became extinct during the late Pleistocene to early Holocene transition. Megafauna extinction, accounting for the loss of over $80 \%$ of large mammal species in SA, coincides with the arrival and spread of humans. Despite far less pronounced climate change in SA compared to other continents, extinction levels are far higher, suggesting human predation and anthropogenic habitat loss played a significant role (Barnosky and Lindsey, 2010). The megafauna influenced the environments of the late Pleistocene, and the extinction of these major ecosystem engineers would have had fundamental impacts on land cover, vegetation succession, fuel load, and nutrient cycling (Doughty et al., 2016a; Doughty et al., 2016b). Megafauna extinction left many plant taxa such as Cucurbita squashes and gourds and large-seeded plants such as avocado (Persea americana), cacao and the Brazilian copal Hymenaea, among others, without mutualist dispersal partners (Kistler et al., 2015; Guimarães et al., 2008). The reduction in large game species and increasing human population densities during the latest parts of the Pleistocene have been argued to have led to increased emphasis on plant exploitation and the early process of plant domestication during the Holocene (Piperno and Pearsall, 1998; Piperno, 2011).

\subsubsection{The beginning of plant cultivation and domestication in tropical South America}

Archaeobotanical studies are providing a far greater appreciation of the role of plants in early colonists' diets in the tropics (Gnecco, 2003; Lombardo et al., 2020; Mora, 2003; Roosevelt et al., 1996) and elsewhere in SA (e.g., Dillehay and Rossen, 2002; Prous and Fogaça, 1999) (Table 1; Supplemental Table 5). It has been shown that plant cultivation and domestication in the New World occurred as early as in other parts of the world (Denham, 2018), with independent origins in North, Central, and SA now apparent, and multiple origins within lowland SA likely (e.g., Bray, 2000; Piperno, 2011). Based on genetic and archaeological evidence, two major centres of plant domestication have been proposed in tropical SA where selection began in the late Pleistocene and early Holocene: SW and NW Amazonia (Piperno, 2011) (Fig. 3).

$N W S A$. This region represents a major early centre of plant domestication, including squashes (Cucurbita ecuadorensis) (Piperno and Stothert, 2003) and C. moschata, yams (Dioscorea), sweet potato (Muñoz-Rodríguez et al., 2018), arrowroot (Maranta arundinacea), leren (Calathea allouia), cocoyam (Xanthossoma safitifolium) and cacao (Clement et al., 2010; Iriarte, 2007; Piperno, 2011; Zarrillo et al., 2018). Archaeobotanical records from NW SA evidence incipient tree, palm and tuber cultivation beginning 11.5ka in the montane forests of Colombia, including the tuber crops Dioscorea sp., Calathea sp. and Maranta cf. arundinacea, along with the tree fruits Persea, Caryocar and Virola (Aceituno and Loaiza, 2018; Dickau et al., 2015; Piperno and Pearsall, 1998), and a variety of palms accompanied by pollen evidence of small forest clearings (Plantago, Asteraceae). The Middle Cauca region is one of the regions where more intensive archaeology and archaeobotany in the tropical South American has been conducted. There, starch grains indicate the cultivation of local root crops such as Dioscorea sp. and Calathea sp. as well Phaseolus sp. beans by $\sim 9.6 \mathrm{ka}$. Manihot esculenta arrives by $\sim 8.4 \mathrm{ka}$ and Ipomoea $\mathrm{sp}$. is first recorded $\sim 7.7 \mathrm{ka}$ (Aceituno and Loaiza, 2014; 2018). These root crops and vegetables are accompanied by tree fruits including soursop (Annona sp.), mora (Rubus sp.) and avocado (Morcote-Ríos et al., 2010). This early food production is accompanied by forest clearing starting around $7 \mathrm{ka}$. The presence of notched axes and waisted hoes, which were likely used for tree-felling and possibly for soil tillage and digging roots, endorse pollen records indicating that these plants were cultivated within a wet and cool montane forest (Aceituno and Loaiza, 2007). Meggers (2001) has proposed that these ground tools, in particular axes with blunt edges, were not used to cut trees, but instead were likely used to process palm starch, shredding the fibre of palm pith, similar to practices carried out in the Old World tropics.

Archaeobotanical records for the Colombian Amazon are also informative. Recent excavations in the Guaviare forest-savannah ecotone show the presence of the palms Astrocaryum chambira, A. sp., Attalea racemosa, A. maripa, Euterpe precatoria, Mauritia flexuosa, Oenocarpus bataua, Syagrus orinocensis, Socratea exorrhiza and Bactris sp. in additio to Brosimum lactescens since $\sim 12 \mathrm{ka}$ (MorcoteRíos et al., 2020; Morcote-Ríos et al., 2014). The early consumption of palms is similar to that attested by the archaeobotanical data from the Amazon lowland forest of Peña Roja (Mora, 2003), which also contains domesticated plants, including squash (Cucurbita sp), bottle gourd (Lagenaria siceraria) and leren (Piperno and Pearsall, 1998). In southern Ecuador 10ka, phytolith evidence documents the domestication of local species of squash, Cucurbita ecuadorensis, at the Las Vegas site (Piperno and Stothert, 2003), along with bottle gourd and Calathea sp. rhizomes accompanied by typical early Holocene plant-grinding implements called 'edge ground' cobbles. The early Holocene residents of Las Vegas site had a broadspectrum subsistence exploiting a mosaic of terrestrial, estuarine and mangrove productive environments (Piperno and Pearsall, 1998). Further south, in the Zaña Valley, on the north coast of Peru, macro- and microfossils, the latter from the calculus of human teeth, document the presence of squash, peanuts, beans, and the tree crop pacay (Inga feuillei) between around 10-7.8ka (Dillehay et al., 2007; Piperno and Dillehay, 2008). Archaeological survey in this region documents a shift in settlement patterns for the purpose of exploiting small but fertile alluvial patches. In the Nanchoc region, the overall evidence suggests that effective food production systems contributing significant dietary inputs were present from the early Holocene. In the Casma valley, the Huaca Prieta record contains palms (Arecaceae), Cucurbita sp. (squash), Persea sp. (avocado), Phaseolus lunatus (lima beans), Schinus molle (Peruvian 
Table 1

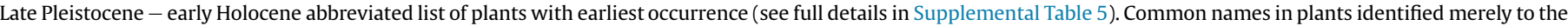

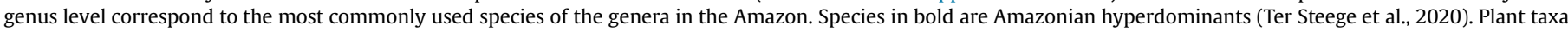

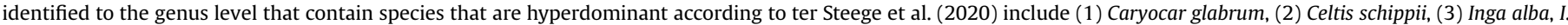

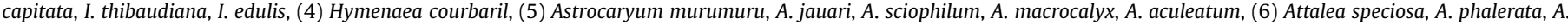
butyracea, (7) Euterpe precatoria, E. oleracea, (8) Alchornea discolor, (9) Apeiba petoumo, (10) Jacaranda copaia, (12) Virola surinamensis.

\begin{tabular}{|c|c|c|c|c|c|c|c|c|}
\hline \multirow{2}{*}{$\frac{\text { Roots and tubers }}{\text { Scientific name }}$} & \multirow[b]{2}{*}{ Common name } & \multirow[b]{2}{*}{$\begin{array}{l}\text { Earliest } \\
\text { (ka) }\end{array}$} & Palms & \multirow[b]{2}{*}{ Common name } & \multirow[b]{2}{*}{$\begin{array}{l}\text { Earliest } \\
\text { (ka) }\end{array}$} & Legumes & \multirow[b]{2}{*}{ Common name } & \multirow[b]{2}{*}{$\begin{array}{l}\text { Earliest } \\
\text { (ka) }\end{array}$} \\
\hline & & & Scientific name & & & Scientific name & & \\
\hline Calathea allouia & lleren, aria & $\sim 11-9.5$ & Acrocomia sp. & corozo & $\sim 11.8-11.3$ & Inga sp. ${ }^{3}$ & ice cream bean & $\sim 11.7-11-2$ \\
\hline Dioscorea sp. & yam, cara, name & 9 & $\begin{array}{l}\text { Astrocaryum } \\
\text { chambira }\end{array}$ & chambira & $\sim 11.8-11.3$ & Phaseolus sp. & bean & 9 \\
\hline Heliconia sp. & & $\sim 12.2-11.8$ & Astrocaryum sp. ${ }^{5}$ & & $\sim 11.8-11.3$ & Prosopis sp. & algarrobo & $\sim 11-10$ \\
\hline Ipomoea sp. & sweet potato, camote & 7.7 & Astrocaryum vulgare & tucuma & $\sim 13.2-11.7$ & Hymenaea sp. ${ }^{4}$ & jatoba & $\sim 10.2-9.9$ \\
\hline Manihot sp. & manioc, yuca & $\sim 10.5$ & Attalea maripa & inaya & $\sim 11.8-11.3$ & Arachis hypogaea & peanut & $\sim 8.4-6$ \\
\hline Maranta arundinacea & arrowroot, arroruz & $\sim 10-9.5$ & Attalea racemosa & & $\sim 11.8-11.3$ & Vegetables & & \\
\hline $\begin{array}{l}\text { Phenakospermum } \\
\text { guyanense }\end{array}$ & $\begin{array}{l}\text { bananeira brava, } \\
\text { soroca }\end{array}$ & $\sim 12.2-11.8$ & Attalea sp. ${ }^{6}$ & babassu & $\sim 11.8-11.3$ & Scientific name & & \\
\hline \multirow[t]{6}{*}{ Xanthosoma sp. } & \multirow[t]{6}{*}{ huitina, taioba } & \multirow[t]{6}{*}{$\sim 10.2-7.5$} & Bactris sp. & chonta, pupunha & $\sim 11.8-11.3$ & \multirow{6}{*}{$\begin{array}{l}\text { Cucurbita spp. } \\
\text { Industrial } \\
\text { Scientific name } \\
\text { Lagenaria siceraria }\end{array}$} & \multirow[t]{6}{*}{ zapallo, abobora } & \multirow[t]{6}{*}{10.3} \\
\hline & & & Euterpe precatoria & acai & $\sim 11.8-11.3$ & & & \\
\hline & & & Euterpe sp. ${ }^{7}$ & & $\sim 9.5-9.4$ & & & \\
\hline & & & Mauritia flexuosa & moriche & $\sim 11.8-11.3$ & & & \\
\hline & & & $\begin{array}{l}\text { Oenocarpus batua } \\
\text { Socratea exorrhiza }\end{array}$ & bacaba, mil pesos & & & & \\
\hline & & & Syagrus orinocensis & yaripa, churubay & $\sim 11.8-11.3$ & & & \\
\hline $\begin{array}{l}\text { Timber trees } \\
\text { Scientific name }\end{array}$ & Common name & $\begin{array}{l}\text { Earliest } \\
\text { (ka) }\end{array}$ & $\begin{array}{l}\text { Tree fruits } \\
\text { Scientific name }\end{array}$ & Common name & $\begin{array}{l}\text { Earliest } \\
\text { (ka) }\end{array}$ & Scientific name & $\begin{array}{l}\text { Medicinal/Narcotic } \\
\text { Common name }\end{array}$ & $\begin{array}{l}\text { Earliest } \\
\text { (ka) }\end{array}$ \\
\hline Anacardium sp. & caju & $\sim 11-10$ & Anacardium sp. & caju & $\sim 11-10$ & Alchornea sp. ${ }^{8}$ & iricurana & $\sim 11.3-9.3$ \\
\hline Anadenanthera spp. & vilca, yopo, angico & $\sim 11.3-9.3$ & Annonaceae & guanabana & $\sim 11.3-9.3$ & Andira sp. & & $\sim 11.3-9.3$ \\
\hline Astronium sp. & aroeira & $\sim 12.2-11.8$ & Bertholetia excelsa & $\begin{array}{l}\text { Brazil nut/ } \\
\text { castanha }\end{array}$ & $\sim 13.2-11.7$ & $\begin{array}{l}\text { Anadenanthera } \\
\text { spp./ }\end{array}$ & vilca, yopo, angico & $\sim 11.3-9.3$ \\
\hline Brosimum lactescens & ojoche blanco & $\sim 12.2-11.8$ & Byrsonima crispa & muruci & $\sim 13.2-11.7$ & Apeiba sp. ${ }^{9}$ & monkey comb & $\sim 11-10$ \\
\hline Hymenolobium sp. & mari mari & 11.3-9.3 & Caryocar sp. ${ }^{1}$ & pequi & $\sim 9.5-9.4$ & Casearia sp. & $\begin{array}{l}\text { café bravo, } \\
\text { guacatonga }\end{array}$ & $\sim 11.3-9.3$ \\
\hline Tabebuia sp. & pau d'arco & $\sim 11.3-9.3$ & Celtis sp.2 & hackberry & $\sim 9.7-9.5$ & Copaifera sp. & copaiba & $\sim 10.2-9.9$ \\
\hline \multirow{4}{*}{ Dalbergia sp. } & rosewood & $\sim 11.3-9.3$ & Mouriri apiranga & muriti & $\sim 13.2-11.7$ & Jacaranda sp. ${ }^{10}$ & jacaranda, carobinha & $\sim 11.3-9.3$ \\
\hline & & & Persea spp. & avocado & $\sim 9.2-8.4$ & Piptadenia sp. & & $\sim 11.3-9.3$ \\
\hline & & & Psidium sp. & guayaba & $\sim 9.5-9.4$ & Psychotria sp. & poaia & $\sim 11.3-9.3$ \\
\hline & & & Coeupia sp. & $\begin{array}{l}\text { castanha de } \\
\text { galinha }\end{array}$ & $\sim 10.2-9.9$ & Virola sp. ${ }^{11}$ & virola & $\sim 10.2-9.9$ \\
\hline
\end{tabular}

peppertree), Prosopis sp. (algarrobo), and Capsicum sp. (chilli) among others between 14.5 and 7.5ka (Dillehay, 2017).

Southwestern Amazonia. Proposed plants in this region include Manihot esculenta subsp. flabellifolia, the wild ancestor of manioc (Olsen and Schaal, 1999); Cucurbita maxima subsp. andreana, the wild ancestor of the squash (Cucurbita maxima subsp. maxima) (Sanjur et al., 2002); Canavalia piperi, the wild ancestor of jack bean (Canavalia plagiosperma) (Piperno and Pearsall, 1998); and Capsicum baccatum var. baccatum, the wild ancestor of chili peppers (Capsicum baccatum var.pendulum) (Scaldaferro et al., 2018). This is also the region of peach palm (Bactris gasipaes) domestication, the only neotropical palm with domesticated populations (Clement et al., 2016). Additionally, this region is the purported cradle of the domestication of important stimulants, such as coca (Erythroxylum coca) (Plowman, 1984), chewed by people at least $8 \mathrm{ka}$ in northern Peru (Dillehay et al., 2010), and tobacco (Nicotiana tabacum) (Gerstel and Sisson, 1995), as well as dyes like annato (Bixa orellana) (Clement et al., 2016).

Recent work (Lombardo et al., 2020) has documented the cultivation of squash (Cucurbita sp.) at about 10.3ka and Manihot sp. at about $10.4 \mathrm{ka}$. The early use of Manihot in Llanos de Mojos coincides with the estimated time for the molecular divergence of the domesticated species from its wild ancestor and with the current biogeography of the closest wild ancestor of manioc (Olsen and Schaal, 1999; Rival and McKey, 2008). Importantly, at this time these early cultivators began to create a landscape that ultimately comprised $\sim 4700$ artificial forest islands within a seasonally flooded savannah. The early use and potential selection of Manihot in this environment is hardly surprising. Manioc's wild ancestors are adapted to forest-savannah ecotones and thrive in ecological successions that are frequently interrupted by disturbances such as fire. Their tuberous roots store underground reserves facilitating rapid regrowth; they exhibit plasticity in growth form according to the openness of the environment and they promptly regenerate from a soil bank (Rival and McKey, 2008). The disturbed environments created by the forest islands must have created perfect conditions for manioc's early ancestors to thrive. Since its wild ancestors do not readily sprout from stems, the timing and specific processes of how the reproductive biology of manioc changed from sexual reproduction to vegetative propagation (under cultivation) are matters to be resolved (Rival and McKey, 2008). The presence of domesticated Cucurbita sp. beginning at around $10.3 \mathrm{ka}$, representing the oldest evidence for Cucurbita sp. in Amazonia. Further studies that analyse larger sample sizes are required to determine whether the domesticated squash cultivated in the early Holocene epoch was adopted in the Llanos de Mojos from other regions or was domesticated in situ. The dates from Llanos de Mojos are broadly contemporaneous with the earliest evidence of Cucurbita sp. in Huaca Prieta 10.5-9ka and in the Nanchoc region $\sim 11-9.8 \mathrm{ka}$ (Dillehay, 2017) indicating that the consumption of Cucurbits was widespread in tropical South America since the start of the Holocene. 


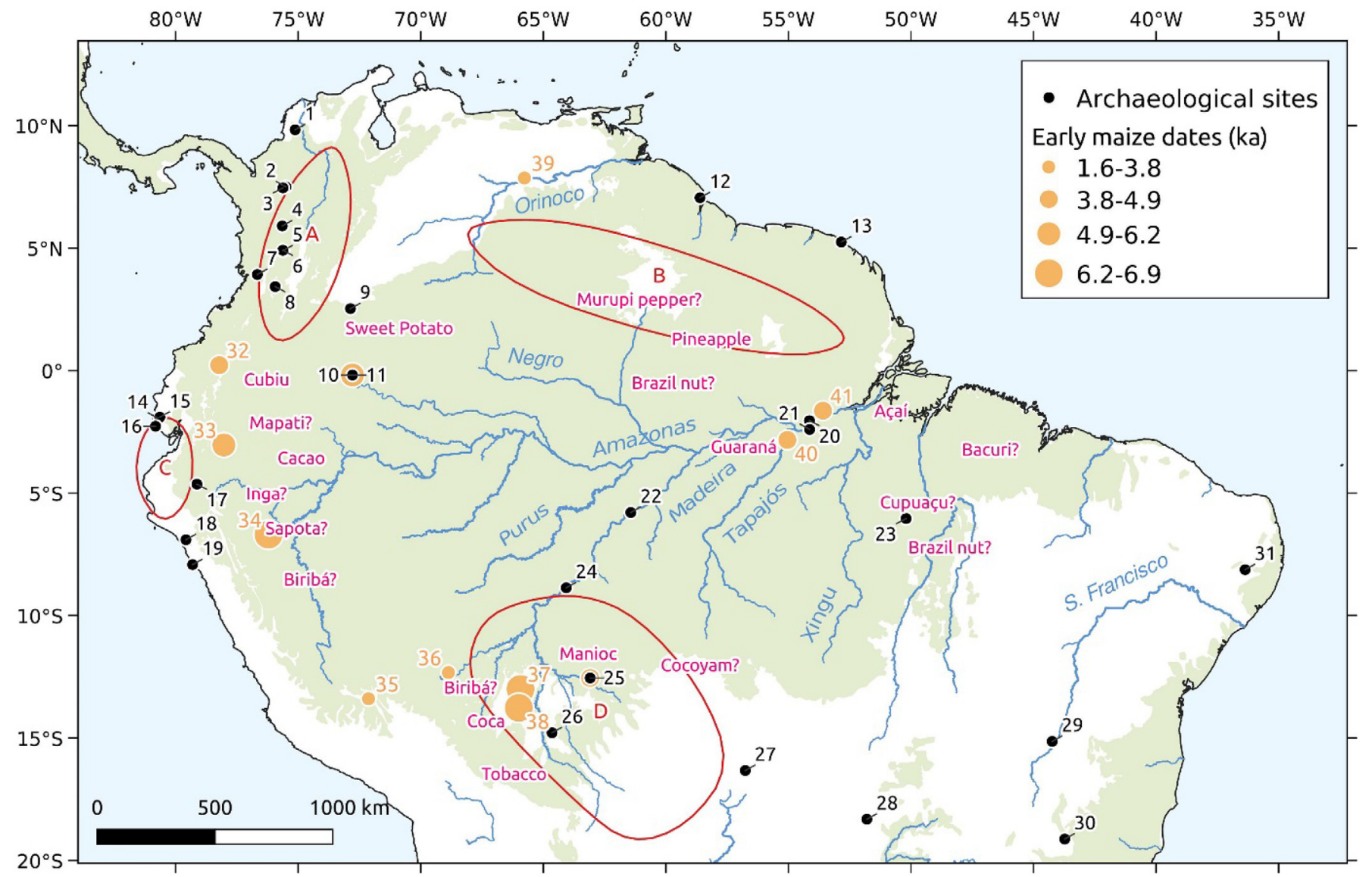

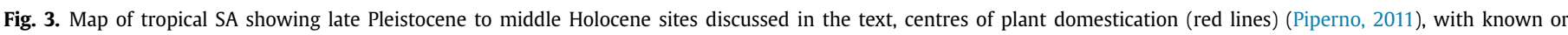

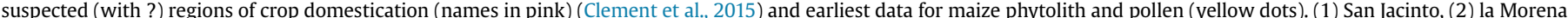

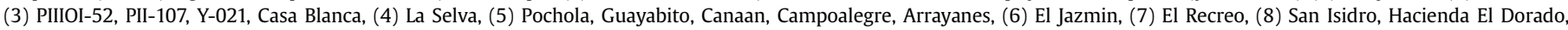

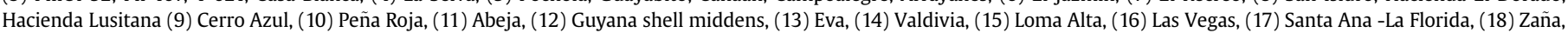

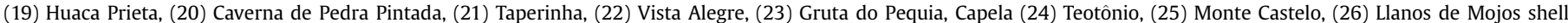

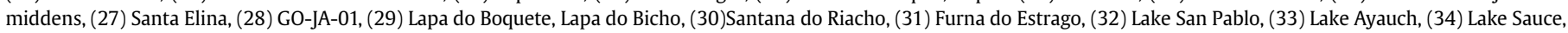

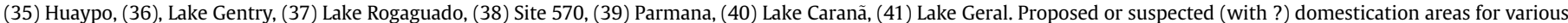

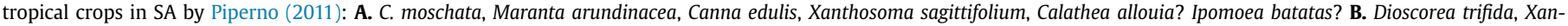

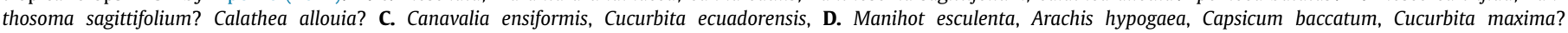


article.)

Also in SW Amazonia, the Teotônio site, an open-air site located on a 40 m-high bluff on the south bank of the Madeira river records the tree fruits guava (Psidium guajava), pequiá (Caryocar sp.), Brazil nuts and leren (Calathea sp.), starting 9ka (Watling et al., 2018). Moving to the eastern Amazon, Caverna da Pedra Pintada show the consumption of tree and palm fruits $\sim 13.1 \mathrm{ka}$, including Hymenaea, Brazil nut, Sacoglottis guianensis, Talisia esculenta, Mouriri apiranga, Coccoloba pixuna, and muruci (Byrsonima crispa), Attalea macrocarpa, A. spectabilis and Astrocaryum vulgare (Roosevelt et al., 1996). Similar records of tree and palm fruits, along with small animals and fish, are recorded at Gruta do Gavião associated with nutbreakers 11.6-8.5ka (Magalhães et al., 2019). A broad-spectrum diet of river fauna and forest tree fruits is recorded at the Itaparica Tradition sites dating to the early Holocene, $13-11 \mathrm{ka}$ (Schmitz et al., 2004) (Table 1; Supplemental Table 5).

This summary corroborates previous assumptions indicating that plant cultivation in the neotropics started in shrub savannahs as well as in seasonal tropical forest environments (Piperno and Pearsall, 1998) but also underscores the role of montane forests as key environments during this process. SW Amazonia is emerging as the fifth centre of early Holocene plant domestication in the world, adding to the other four: two in the Old World (Near East and China) and two in the New World (southwestern Mexico and NW SA) (Larson et al., 2014). Our current data indicate that the colonisation of the neotropics was based on a reliance on palm, tree fruits and underground tubers. It comes as no surprise that phytoliths derived from plants that produce underground storage organs-including Manihot, Calathea, Marantaceae, Heliconia, Cyperaceae and Phenakospermum - constitute an important part of the total phytolith assemblages from the earliest records of NW SA and SW Amazonia. Root plants are pre-adapted and abundant in savannahs with long dry seasons (Piperno and Pearsall, 1998) and are concentrated in wetlands (Dillehay and Rossen, 2002). They produce carbohydrate-rich foods that, with the exception of some varieties of manioc (McKey et al., 2010a), are easy to process and cook. They are consumed by indigenous groups (Hanelt et al., 2001) today, and probably provided a considerable part of the calories consumed by the first inhabitants of the Llanos de Mojos. Many, such as Dioscorea yams and Ipomoea tubers, are amenable to vegetative propagation within gardens or in their 'natural' habitats via paracultivation (sensu Dounias, 2001). Our data are consistent with the hypothesis that plants that produce underground storage 
organs were a fundamental part of the diet of human populations as they colonised new territories (Aceituno and Loaiza, 2018; Jones, 2009). Palms, an essential resource for tropical forest residents, providing food (palm fruits) and construction materials (thatch, fibres and wood), also appear to have played a major role in the diet of these early colonisers. They are predominant in early archaeobotanical records across lowland Amazonia, and changes in vegetation composition to greater proportions of palm is closely associated with humans from their first appearance (Morcote-Ríos and Bernal, 2001). The diets of these early settlers and first cultivators were certainly complemented by other faunal and terrestrial resources (Capriles et al., 2019; Morcote-Ríos et al., 2020; Roosevelt et al., 1996). Intriguingly, many of the earliest plants consumed by humans in the tropics later became Amazonian hyperdominants (shown in bold below in Table 1) (Levis et al., 2017).

Regarding their impact on the environment, it is during these initial phases that early Amazonian foragers may have started to create groves of edible fruit-bearing trees. The recurrent discard of seeds/nuts at frequently-visited locales is recorded ethnographically in the Nukak (Politis, 2009). These groups were likely taking advantage of naturally disturbed areas such as tree falls, landslides or lighting strikes, similar to today's Hoti practices in Venezuelan Guayana (López-Zent and Zent, 2004). The use of fire was likely common in seasonal forests, savannahs and forest-savannah ecotones. The presence of axes in the early records of the Cauca River Basin attests to the ability of people to fell trees, which likely contributed to disturbance and clearance of these montane forests (see Levis et al., 2018 for a summary of how indigenous and traditional Amazonian people have managed forest resources to promote useful plant species).

To establish the extent to which these subtle changes resulted in enduring anthropogenic settings requires further inter-disciplinary work. However, the evidence from the Llanos de Mojos suggests a strong relationship between landscape and plant domestication in the Americas, long argued for Amazonia by Clement (1999a). A study by Lombardo et al. (2020), which documented thousands of anthropic keystone structures, represented by forest islands that likely had lasting repercussions for habitat heterogeneity, shows that the human footprint in Amazonia is not restricted to largescale transformations by farming groups in the late Holocene epoch. Similar practices recorded ethnographically by the Kayapó, of creating resource-rich forest islands (Hecht, 2009; Posey, 1985), may well go back to the very start of the Holocene. A mosaic-like pattern, with multiple areas of early independent agriculture, is reflected in the diversity of land use practices shown by early foodproducing economies that emerged in different parts of the continent. Intriguingly, the presence of domesticated squash phytoliths $10.3 \mathrm{ka}$ in the Llanos de Mojos opens the possibility that this region was colonised by groups already engaged in plant cultivation (Lombardo et al., 2020).

\subsection{Middle Holocene (8.2-4.2ka): The beginning of food- production economies}

It has long been proposed that there is a gap between plant cultivation and domestication and the development of agricultural economies in lowland SA and adjacent regions (Fausto and Neves, 2018; Lombardo et al., 2020; Neves, 2007; Piperno, 2011). As has been previously suggested for central Amazonia (Neves, 2007) and eastern Brazil (Araujo et al., 2005), a recent analysis of archaeological radiocarbon data shows a decline in population during the middle Holocene across SA, including Amazonia, after 8.6ka (Riris and Arroyo-Kalin, 2019). We should take into account that the absence of archaeological evidence could be related in part to geomorphic processes (Lombardo et al., 2012; Lombardo et al., 2019) or the lack of archaeological work in many regions. New archaeological projects are progressively filling this gap. For example, forest islands of SW Amazonia that started as shell middens are some of the few sites that provide us with a continuous window to the Amazon past from the early to the late Holocene (Capriles et al., 2019; Lombardo et al., 2020; Lombardo et al., 2013b; Pugliese et al., 2018). New evidence is also emerging in the northern rim of the Amazon. Pagan-Jiménez et al. (2015) document the presence of maize, sweet potato, Zamia sp, Canavalia sp, and Capsicum sp. at the Eva site in French Guiana between $\sim 6$ and 3.9ka. In coastal Guyana, the analysis by Daggers et al. (2018) of bone isotopes from 81 individuals from shell mounds dating to $\sim 7.5-2.6 \mathrm{ka}$ show values indicative of C3 plants resource use in an open canopy environment.

This population decrease is coeval with the onset of more arid conditions and marked precipitation variability across SA (Deininger et al., 2019). Smith and Mayle's (2018) comprehensive synthesis of palaeoecological records revealed the heterogeneous impact of precipitation changes resulting from these more arid middle Holocene conditions in the Southern Hemisphere tropical SA forests, which is related to reliance on precipitation from the South American summer monsoon (SASM). They showed that while some areas in SW Amazonia and SE Brazil (largely reliant on precipitation from the SASM) favoured more open savannahs, grasslands and the expansion of the forest-savannah mosaic during the middle Holocene, the tropical forests of central, western and eastern Amazonia did not experience major changes, changes, consistent with these regions experiencing an increase in precipitation during the middle Holocene (antiphased to these other regions) (Wang et al., 2014). The drier climate of the Holocene has implications for the interpretation of the charcoal records. Today, natural fires are not the norm in the humid forests of Amazonia, thus the occurrence of fossil charcoal is generally attributed to human ignition (Bush et al., 2008). However, care should be taken, since the driest climates of the middle Holocene may have increased the probability of natural fires, meaning that it is more difficult to disentangle human from natural causes (see Montoya et al., 2020).

Despite the decline in populations shown in radiocarbon databases, and the apparent gap in many regions, the progressive application of archaeobotanical and palaeoecological analyses has documented the domestication of native crops and the dispersal of exotic ones during the middle Holocene. The details of plant taxa recovered during the middle Holocene are shown in Supplemental Table 5. Modern and ancient DNA, along with microbotanical analysis, have evidenced the use of cacao in the Ecuadorian Amazon from about 5.3ka (Zarrillo et al., 2018), at Santa Ana La Florida. In the same region, Zarrillo (2012) has documented the presence of Ipomoea batatas $\sim 5.6 \mathrm{ka}$.

Maize, which was domesticated in the Balsas River Basin, Mexico, $\sim 8.7 \mathrm{ka}$, from Zea mays sp. parviglumis (Piperno et al., 2009b), arrived in lowland SA at the start of the middle Holocene epoch. It is likely that it initially diffused into northern SA through the drier inter-Andean valleys and the lower elevations to the east of the Andes (Piperno and Pearsall, 1998). Maize pollen shows a temporal gradient of dispersal that begins in W Amazonia $\sim 6.9 \mathrm{ka}$ and reaches the eastern Amazon 4 .3ka (see summary in Maezumi et al., 2018) (Fig. 3). In NW SA, the earliest reliable dates come from the middle Caquetá River at the Abejas site 5.5ka (Mora et al., 1991). For the Amazonian lowlands, the earliest date comes from the Llanos de Mojos, documented at 6.9ka (Isla del Tesoro, Lombardo et al., 2020) and 6.5ka (Lake Rogaguado, Brugger et al., 2016), with similar dates for the Ecuadorian Amazon at $6.3 \mathrm{ka}$ 
(Lake Sauce, Bush et al., 2016) and 6ka (Lake Ayuach, Bush et al., 1989). A genetic analysis by Kistler et al. (2018) suggests that the early sixth-millennium maize found in different records across SW Amazonia was probably a partially domesticated variety that later diverged into two South American groups of fully domesticated maize varieties. Given the adaptability of maize as a food plant, and that plant domestication is a continuous process, this is hardly surprising.

It is also during the middle Holocene that manioc likely spread from SW Amazonia to other regions of Amazonia (Arroyo-Kalin, 2012) and beyond, including northern Peru (8.5ka), Colombia (7ka) and Panamá (7.6ka) (Piperno, 2011), suggesting that the exchange of cultivars between Amazonia and the Andes began in the early Holocene epoch. There are two major groups of manioc varieties: sweet varieties have low amounts of toxic substances (cyanogenic glycosides) and may be consumed with minimum processing, while bitter varieties have a high degree of toxicity and must be detoxified before consumption (McKey and Beckerman, 1993). Arroyo-Kalin (2010) has eloquently argued that during the early and middle Holocene sweet manioc was likely grown along with maize in refuse middens and house gardens in the periphery of the Amazon basin, while the cultivation of bitter manioc evolved as the result of the agricultural intensification in fields that took place during the late Holocene, with the regional spread of ADE into the centre of the basin. Recent genetic analysis suggesting that sweet varieties of manioc originated during the initial domestication is SW Amazonia followed by bitter varieties lend support to Arroyo-Kalin's model (Santos Mühlen et al., 2013). A similar scenario of spread during the middle Holocene can be detected for sweet potato, from the earliest dates in the Middle Cauca Valley 7.7ka (Aceituno and Loiza, 2018) arriving to the Caribbean and coastal French Guiana 6.6ka (Pagán-Jiménez et al., 2015) and the Ecuadorian Upper Amazon 5.6ka (Zarrillo, 2012).

SW Amazonia is also where wild varieties of peanuts (Arachis hypogaea) occur today. Early archaeobotanical evidence has not been forthcoming for this epoch, but Favero and Valls (2009) proposed a date of 7-6ka for the start of peanut domestication. The middle Holocene also sees the first appearance of Amazonian anthrosols in the Upper Madeira 6ka (Miller, 1992; Watling et al., 2018), while in the middle Caquetá River region, small-scale but permanent communities were growing maize and manioc on Amazonian anthrosols $\sim 5.5 \mathrm{ka}$ (Mora et al., 1991). The middle Holocene is possibly when the dispersal of other important native crops, such as Brazil nut (Shepard and Ramirez, 2011) and cacao (Zarrillo et al., 2018) occurred across the basin. Watling et al. (2018) suggest that ADE formation at the Teotonio site $\sim 6 \mathrm{ka}$ allowed for the adoption of and experimentation with exotic crops such as Cucurbita and Phaseolus.

Reviewing all the evidence from areas adjacent to the Amazon is outside the scope of this article (see detailed works of Dillehay, 2011; Piperno and Pearsall, 1998). Collectively, though, this evidence shows that the large and uncharted gap of low-level food producers (Smith, 2001) between initial plant cultivation and domestication and formative agriculture is beginning to be filled with new data. Irrespective of the designations we employ for analytical reasons, characterising the majority of middle Holocene societies as mobile hunters and gatherers or as groups of foragers who augmented their diets with small portions of cultivated foodstuffs is likely inappropriate (see Iriarte, 2009).

\subsection{The late Holocene (4.2ka-present): The Amazonian formative}

The late Holocene was characterised by major climatic changes. All palaeoclimate records in the regions influenced by the SASM demonstrate a consistent long-term trend of increasing precipitation, starting during the mid-Holocene $\sim 6 \mathrm{ka}$ and showing a rapid rise up to $4 \mathrm{ka}$, then continuing to increase slightly towards the present (see summary in Iriarte et al., 2017). Palaeovegetation reconstructions show that the proportion of sites with a forestdominated catchment increases consistently through the mid-late-Holocene, between around $5 \mathrm{ka}$ and $1 \mathrm{ka}$, as exemplified by the expansion of the southern Amazon rainforest margin at the expense of savannahs (Carson et al., 2014; Flantua et al., 2015b; Mayle et al., 2000), at the seasonally dry tropical forest margins in the Chiquitanía region of lowland Bolivia, and at the southern margin of the Cerrado (savannah) biome (Ledru, 1993; OliveiraFilho and Ratter, 1995).

During the late Holocene Amazonian farmers transformed the landscape at a scale not seen before across lowland SA. This is evidenced by the long-term modifications in soils resulting in Amazonian Dark Earths and the transformation of vast expanses of seasonally flooded savannahs into raised field agricultural landscapes, which mark the beginning of the Amazonian Formative (Arroyo-Kalin, 2010; Supplemental Text 1). The construction of raised and drained fields, water management canals, artificial ponds, landscape-scale fish weirs, the formation of ADEs and forest enrichment are all examples of landesque capital, which entails investment in infrastructure and landscape modifications that provide increased yields not only for the duration of one's lifespan, but also for future generations (Håkansson and Widgren, 2016). These major landscape transformations are generally correlated with the spread of farmers associated with the ancestors of major linguistic families including the Arawak, Tupi, Caribs as well as several other smaller groups such as the Pano and Tukano (Epps and Salanova, 2013; Eriksen, 2011; de de Souza et al., 2020; Heckenberger, 2002; Heckenberger and Neves, 2009; Hornborg et al., 2014; Noelli, 2008) and with ceramic traditions (Barrancoid, Pocó-Açutuba) associated with the beginning of sedentary life (Hornborg et al., 2014; Myers, 2004; Neves et al., 2014). As these farming populations spread, they accrue crop genetic resources, creating centres of crop genetic diversity, evidencing the transformation and diversification of plant resources (Clement, 1999a, b) (Fig. 4). Lastly, Hilbert et al. (2017) have produced clear evidence for the third independent global event of rice (Oryza sp.) domestication, beginning about $4 \mathrm{ka}$ in the seasonally flooded savannahs of the Guaporé River at the Monte Castelo site. Noticeably, this crop was domesticated after maize and squash had become an integral part of the economy of Amazonian pre-Columbian groups living in shell mounds along the wetlands of the Guaporé River (Hilbert et al., 2017). Rice domestication also highlights the role of seasonally flooded savannahs and riverine wetlands, which today comprise up to $10 \%$ of lowland SA, as important areas of plant domestication.

\subsubsection{Amazonian anthrosols}

In this review, we focus on the highly modified anthrosols traditionally known as Terras Pretas do Indio and more recently as Amazonian Dark Earths (ADEs), which are arguably one of the most compelling pieces of evidence of human transformation of tropical environments in the Americas (Arroyo-Kalin, 2019; Glaser and Woods, 2004; Heckenberger and Neves, 2009; Lehmann et al., 2004; Petersen et al., 2001; Schaan, 2012; Woods et al., 2009). In the last three decades, ADE research has fostered inter-disciplinary investigations including soil science, agroecology, ethnobotany, archaeology and remote sensing which are largely summarised in the volumes of Glaser and Woods (2004), Lehman et al. (2004), Woods et al. (2009), and Teixeira et al. (2010). Though our synthesis is admittedly biased towards ADEs, not all late Holocene complex 


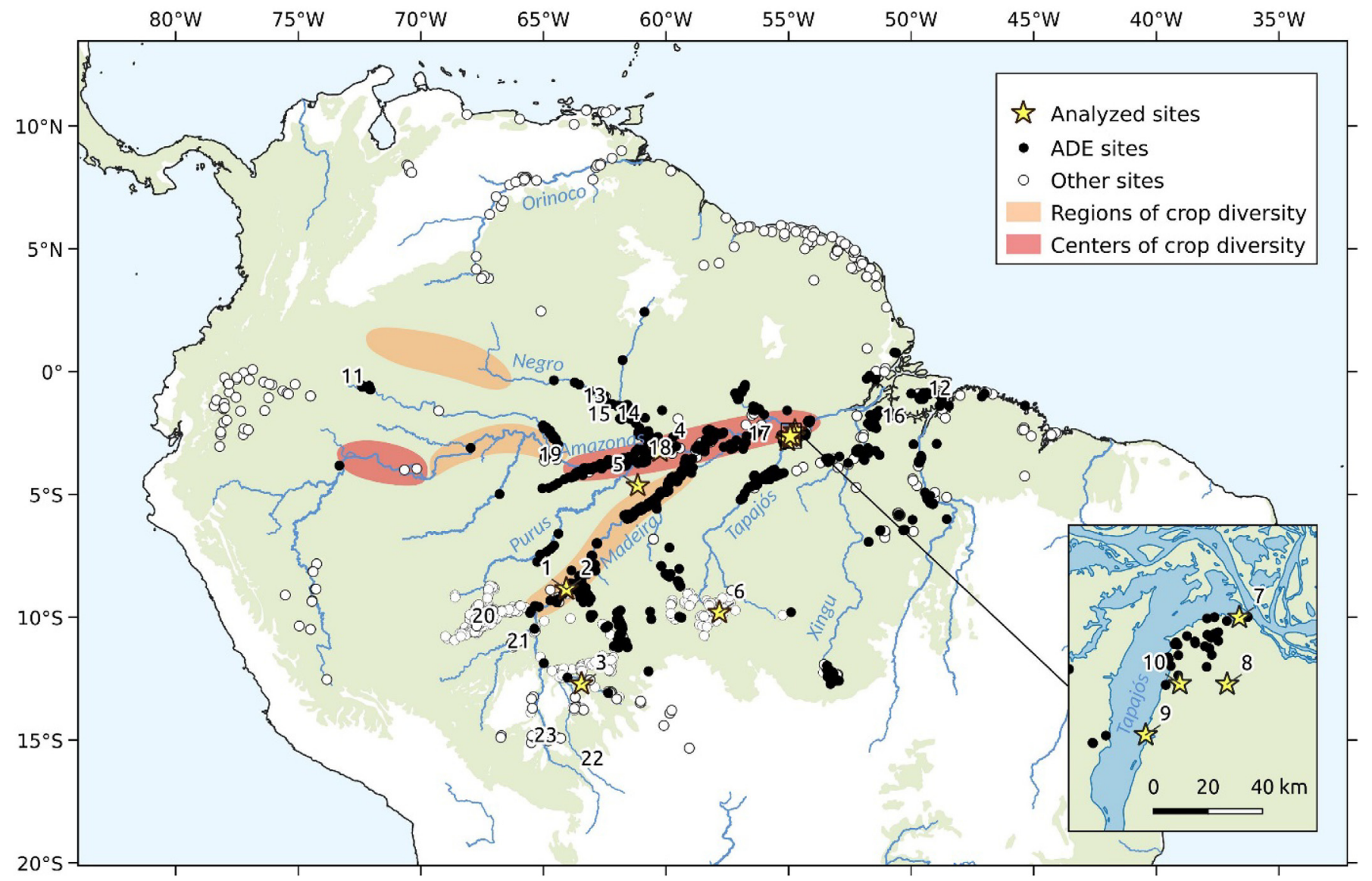

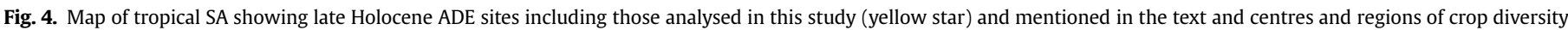

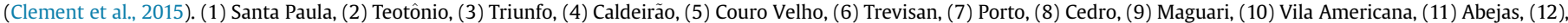

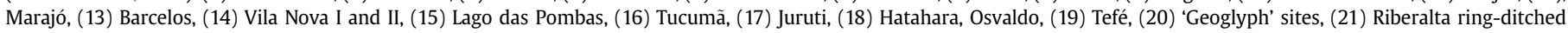


this figure legend, the reader is referred to the Web version of this article.)

societies of the Amazon exhibit ADEs. Noticeable among them are, for example, the geometrically-patterned ditched enclosures (geoglyphs) of Acre (Schaan, 2012), the Marajoara at the mouth of the Amazon River (Schaan, 2012), and the Upano Culture in the Ecuadorian Amazon (Rostain, 2012). The latter occurs in a region with the wettest climate and most fertile soils of the basin, where slash and char (tapados) was likely predominant (Denevan, 2001).

Although we generally refer to Amazonian Dark Earths (ADEs) as one category of anthrosols, soil scientists, geographers and archaeologists have long recognised two types of ADEs: Terras Pretas or Amazonian Dark Earths (hereafter ADEs) and Terras Mulatas or Amazonian Brown Earths (hereafter ABEs). ADEs have been more intensively studied than ABEs, therefore the summary presented below is mainly related to studies carried out in ADEs. In Amazonia, where typical terra firme soils are generally heavily leached and infertile, ADEs are noted for their black colour (Munsell colours 7.5 YR 2/1 to 3/2; 10 YR 2/1 to 2/2), (see Kern et al., 2017:695), their high content of charcoal and organic matter, and their higher $\mathrm{pH}$ values and greater concentrations of $\mathrm{P}, \mathrm{Ca}$, and $\mathrm{Mg}$ which enable them to maintain nutrient levels over hundreds of years (see chapters in Glaser and Woods, 2004; Lehmann et al., 2004; Teixeira et al., 2010; Woods et al., 2009).

ADEs are very broadly distributed in Amazonia. They are generally located on strategically advantageous topographic positions on non-floodable land (terra firme) such as plateaus overlooking rivers and streams (Heckenberger et al., 2008; Kern et al.,
2003; Schaan, 2012; Stenborg et al., 2012). On major rivers they are generally located on high terraces (Denevan, 1996). Predictive modelling by McMichael et al. (2014) estimated that ADEs may have covered as much as $3.2 \%$ (ca. $154,063 \mathrm{~km}^{2}$ ) of the Amazon basin. This prediction is largely based on the available ADE data, at present mostly restricted to main rivers where archaeological surveys have been carried out. However, mounting evidence showing the presence of ADE sites in interfluvial areas (de Souza et al., 2018; Franco-Moraes et al., 2019; Gonda, 2018; Heckenberger et al., 2008; Levis et al., 2012; Levis et al., 2014; PazRivera and Putz, 2009; Schaan, 2012) indicates that this figure is likely an underestimation of the extent of ADEs. In terms of chronology, evidence from NW and SW Amazonia has shown that ADEs are as old as 6ka (Mora et al., 1991; Watling et al., 2018), although widespread formation of ADEs across the Amazon began 2.5ka.

Although many of the sites recorded are less than 2 ha in area (Kern et al., 2003), some sites are large, reaching several hundred hectares. For example, the Santarem site in the lower Amazon may have covered over 500 ha (Roosevelt, 1987a), while Açutuba site in the lower Rio Negro extended over $3 \mathrm{~km}$ of river bluff covering 30 ha (Heckenberger et al., 1999). Typically, ADEs are developed from Ferralsols and Acrisols, but also form in association with other soil types including Arensols, Podzols, Luvisols, Nitisols and Cambisols (Kern et al., 2003). Their depth varies from 15 to $370 \mathrm{~cm}$ and they are associated with a diversity of archaeological remains. Available studies show that the charcoal content of ADEs is 

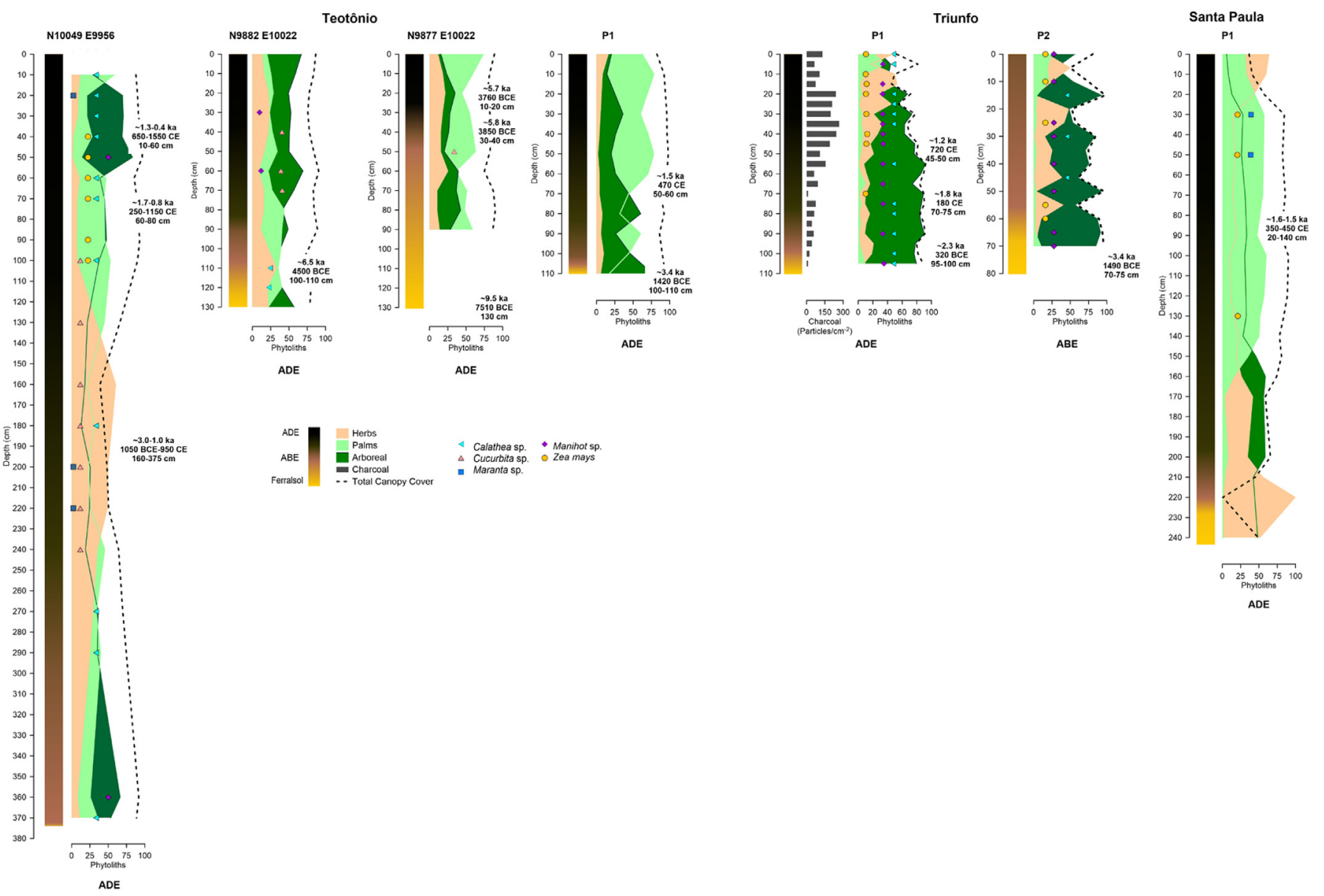

Fig. 5. Summary of soil-depth phytolith diagrams from south-western Amazonia.


Fig. 6. Summary of soil-depth phytolith diagrams from the central Amazon. 
Cedro
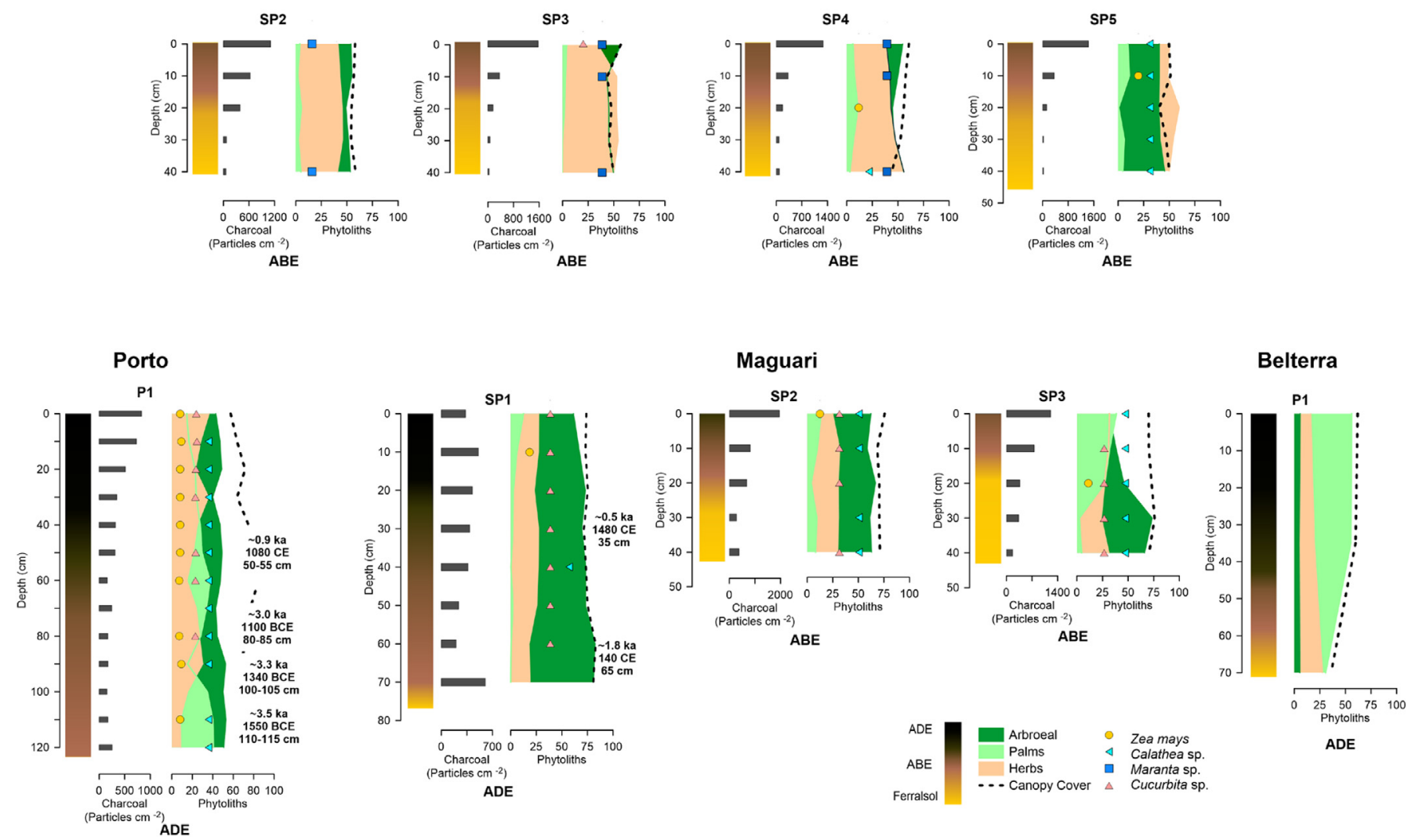

Fig. 7. Summary of soil-depth phytolith diagrams from eastern Amazonia.

generally four times greater than that of neighbouring soils, but can be as much as 70 times higher in the first $30 \mathrm{~cm}$ of soil profiles (Glaser et al., 2001). Pyrogenic carbon contributes to a stable soil organic matter (SOM) stock, with high nutrient retention capacity, such that it may persist in the environment for centuries, even under the intensive leaching characteristic of tropical soils. Collectively, these properties make ADEs some of the most fertile soils in the world (e.g., Lehmann et al., 2003).

There is a general consensus among archaeologists and geographers that Terra Preta ADEs are cultural deposits created through the decomposition of waste around habitation areas, including plant and animal food wastes, fish bones, human excrement and plant materials used for construction, among others (Glaser and Birk, 2012; Woods et al., 2009). They are generally filled with ceramics and other cultural artefacts/ecofacts and are seen as the result of midden refuse accumulation from permanent habitation sites (e.g., Erickson, 2004; Kern and Kampf, 1989; Woods and McCann, 1999). Their variability in thickness and composition-both within and between sites - is generally attributed to differences in the composition of refuse deposited, or to the intensity, duration, nature, and distribution of human activities (Hecht, 2003; Kern et al., 2017).

ADE productivity is based on their high nutrient availability and levels of OM. Studies in traditional and indigenous communities tend to show that ADEs are used to plant nutrient-demanding crops. In the lower Tapajós and the central Amazon, they generally use ADEs to plant maize, beans (Phaseolus spp.) and squash (Cucurbita spp.), among others crops (German, 2003; Hiraoka et al., 2004; Woods and McCann, 1999). In other less commercially oriented areas, like the middle Madeira River, traditional communities use ADEs to farm many varieties of manioc that grow productively in them (Fraser, 2010; Fraser et al., 2012; Fraser and Clement, 2008). Maize grows well in fertile, non-acidic soils, and is usually intercropped with other cultivars such as squash and beans. For example, the Kuikuro indigenous group of the Upper Xingu plant their staple crop manioc in the upland terra firme soils, while the other more nutrient-demanding crops such as maize, papaya (Carica papaya) and tobacco (Nicotiana tabacum) are farmed in ADEs created around modern and abandoned villages (Schmidt and Heckenberger, 2009). The modern Araweté group inhabiting the liana forest of the Xingu River prefer to plant their maize on the nutrient-rich ADEs which they claim 'makes the corn grow' and/or 'makes the corn happy' (Balée, 2013:44). ADEs can produce high yields for both maize and manioc farming. Available data from the central Amazon for maize production in ADEs suggest similar results to those of modern experiments in raised field agricultural systems in different neotropical savannahs (Iriarte et al., 2010). Data from multiple measurements on two ADE sites in central Amazonia show an average yield of $3.925 \mathrm{t} \mathrm{ha}^{-1}$ at Apui and a range between 3.6 and $6 \mathrm{t} \mathrm{ha}^{-1}$ at the Caldeirão research station (Wenceslau Teixeira, Pers. Comm. 2010). Major et al. (2005) reported that in comparison with the typical nutrient-poor Amazonian Oxisols, maize yields can be up to 65 times greater on ADEs. It is interesting to note that while raised field soils which supported maize in the past are currently depleted of nutrients (McKey et al., 2010b; Rodrigues et al., 2020), ADEs continue to be extremely fertile.

Archaeobotanical data is at a very early stage in ADEs but is providing invaluable data. For example, in the Araracuara region of the Colombian Amazon, pollen data from several ADE sites, beginning around $790 \mathrm{CE}$, have documented the presence of a 
diversity of plant resources including tuber crops such as sweet potato and manioc, maize, fruit trees such as cashew-nut (Anacardium occidentalis) and maraca (Theobroma bicolour), palms, including Astrocaryum, Euterpe, Geonoma and Iriartea, along with spices like chilli peppers (Capsicum chinensis) (Herrera et al., 1992). In the central Amazon, phytolith analysis from an artificial mound context built with surrounding ADE soils at the Hatahara site documented the presence of maize, squash (Cucurbita sp.), gourd (Lagenaria sp.) and Calathea, in addition to Heliconia and Bactristype palm phytoliths 1 1.0ka ( 1000 CE) in the Hatahara site (Bozarth et al., 2009). Additionally, maize and yam (Dioscorea sp.) starch grains and maize, Cyperus sp., and palm phytoliths were recovered from plant processing tools collected in a peripheral area of the Hatahara site, associated with two occupations between 600 and 1100 CE (Fernandes Caromano et al., 2013). Manioc carbonised stems and root were recorded in sediments from the same context (Caromano, 2010). Macro-remains of maize have been recovered at the Osvaldo site, central Amazon, with associated dates of ca. $1.3 \mathrm{ka}$ (Shock et al., 2014). Brazil nuts have been recovered at the Teotônio site $26.5 \mathrm{ka}$ in the Upper Madeira, Lago das Pombas 230-390 CE, Porto ( 1000 CE), Vila Nova I (300 BCE, 2.3ka), Vila Nova II (900-1600 CE) in the Central Amazon, and Porto 1000 CE in the Lower Tapajós (Shock et al., 2014). In the eastern Amazon, Gomes (2008) identified maize, manioc, Bactris sp., and Mauritia flexuosa from the starch grains and phytolith residues on plant processing tools at two ADE sites in Santarem, dated to $1.3-0.9 \mathrm{ka}$. See details of plant taxa recovered during the middle and late Holocene in Supplemental Table 5.

ADEs are often surrounded by patches of ABEs. Usually, there is not a clear cut boundary between ADEs and ABEs but there is a diffuse transitional gradation between the two. ABEs are generally more extensive, lighter in colour (dark brown to brown or brownish-grey), shallower, and have an A-horizon with a high organic matter and charcoal content. Archaeological features and remains in ABEs are rare or absent, so they are seldom recognised as archaeological sites and less attention has been paid to their study. Woods and McCann (1999) evidenced that ABEs around Santarem have slightly higher total carbon but lower $\mathrm{P}$ and Ca values, suggesting intensive burning of mulch purposely added. Micromorphology studies by Arroyo-Kalin (2010) show evidence of a clear truncation between the lower part of a well-preserved buried A horizon and its underlying B horizon, indicating some form of scraping, raking and churning. The strong magnetic susceptibility of the ABEs indicates that iron in the soil became magnetised through heating in situ, suggesting management practices involving near-surface burning of organic matter (Arroyo-Kalin, 2014). Costa et al. (2013) showed that ABE locations exhibit signs of successive burning of organic matter, transformation of minerals (maghemite to goethite), and re-firing of ceramic artefacts. A critical aspect of $\mathrm{ABE}$ formation seems to have been a burning practice that left intact charcoal which, unlike ashes, is not degradable. This incomplete 'slash and char', 'cool' burning contrasts with today's prevailing practise of slash and burn, in which after a long period of drying out combustion is hot and complete (Denevan, 2004).

The spatial extent of ABEs has been little studied. Like ADEs, they appear to be a pan-Amazonian phenomenon, reported from the middle Caquetá River to the eastern Amazon (Kern et al., 2017) (Fig. 4), but more research into ABEs is urgently needed. From the few studies that report its dimensions, it appears that ABEs can be anything from three times larger in area than the associated ADE, as at Triunfo site, SW Amazonia, to ten times larger, like the ones reported around Juruti near Santarem (Costa et al., 2013). They can range from 10ha, as reported in the middle Madeira River (Fraser et al., 2009) to an estimated 1000 ha in the Belterra plateau
(Sombroek, 1966; Woods, 2009).

As shown in the summary above, our understanding of how these soils were formed has increased dramatically in the last two decades. But very little is known about their associated land use practices. Important research questions remain unanswered, including: what annual and perennial crops were consumed at ADEs and planted in ABEs? What was the extent of forest clearing associated with Amazonian anthrosols? Were ADE residents enriching the forest with edible plants? Were they practising agroforestry? What was the role of fire in these agro-ecosystems? To address these issues, we carried out integrated archaeological, archaeobotanical, and palaeoecological studies in three regions of Amazonia: eastern Amazon (Santarém), central Amazon (PurusMadeira interfluves) and SW Amazonia (Reserva Forestal Itenéz).

\subsubsection{Animal domestication}

Another way in which the tropical forest form of agriculture differs from the Eurasian model is in the paucity of domesticated animals (see Roberts, 2019). In Amazonia, recent faunal evidence dating to 1.4 to $0.6 \mathrm{ka}$ (400-1400 CE) from the Loma Salvatierra, in the Monumental Mound Region, Llanos de Mojos, documented duck (Carina moschata) remains with osteo-pathological modifications in the foot bone and sex/age ratios consistent with domestication (von den Driesch and Hutterer, 2011). Duck remains have also been recovered from other sites in the region (Prümers, 2002) and throughout the neotropics (Stahl, 2008). This evidence corroborates early traveller accounts from the Paraná basin (de Vaca, [1542] 1906) and missionary reports from the Llanos de Mojos (Eder, [1772] 1985), which mention the ubiquitous presence of domesticated duck in indigenous villages as a staple food combined with maize. Importantly, Angulo (1998) raises the possibility that even more important than as a food source, ducks may have been brought under domestication to keep pests under control in cultivated fields. Native Amazonians also built large infrastructures to capture fish during the flooding season in the Llanos de Mojos. Fish weirs are common in the flooded savannahs, where they occur as zigzag structures with linear segments of raised earth (up to $5 \mathrm{~km}$ long; $1-2 \mathrm{~m}$ wide; and $20-50 \mathrm{~cm}$ tall) that change direction every $10-30 \mathrm{~m}$. They are interrupted by V-shaped structures (1-3 m tall, and 1-2 m wide) associated with small circular ponds (0.5-2 m deep; $10-30 \mathrm{~m}$ in diameter). Fish weirs provided a means to manage and harvest fish that migrated into and spawned in these seasonally inundated savannahs, and were then trapped, during their out-migration, in V-shaped structures and ponds as the floodwaters receded (Blatrix et al., 2018; Erickson, 2000; McKey et al., 2016; Prestes-Carneiro et al., 2019). In addition, wooden corrals were constructed along major rivers to keep stocks of turtles (Acuña, 1891 [1641]).

\section{Novel data on Amazonian Dark Earths}

\subsection{Materials and methods}

We compiled 23 Amazonian anthrosol phytolith soil-depth profiles (14 ADEs, 9 ABEs) from ten sites across SW (7), Central (7) and E Amazonia (9) (see site descriptions and methodology in Supplemental Information, Supplemental Table 1). We only included data that (i) had a precise location, (ii) were collected in direct association with Amazonian anthrosols (i.e. associated with archaeological remains), and (iii) contained phytolith data with sufficient detail for it to be categorised as originating from grass/ herbs, arboreal, palms or crops, and charcoal data where this was present (Fig. 4; Supplemental Table 6), and so could be examined in terms of canopy cover, annual and perennial crops, agroforestry and 
fire regimes. Amazonian anthrosols that have not been classified either as ADE or ABE have been included in the ADE category. Lake Caranã (eastern Amazon) and Lake Versalles (SW Amazon) were selected because these lakes (i) have nearby ADEs with reasonable cultural chronology, (ii) the pollen rain and charcoal particles that the ADEs' land use systems produced can be captured in their sediments, and (iii) the existence of local palaeoclimate records facilitates disentangling natural from human-induced vegetation and fire changes.

We interpret the presence of crop taxa from (i) ADEs as evidence of consumption in habitation sites and/or cultivation in home gardens, (ii) ABEs as evidence of cultivation in fields, and (iii) lakes as evidence of cultivation near lakeshores. We consider arboreal pollen percentages and charcoal influx from lake records, which have a finer chronological resolution and capture the vegetation around archaeological sites, as a more reliable indicator of regionalscale $\left(>10 \mathrm{~m}^{\wedge} 2\right)$ arboreal cover and fire regimes. Alternatively, arboreal phytoliths tend to be deposited in situ and are thus interpreted as representing local scale $\left(<1 \mathrm{~m}^{\wedge} 2\right)$ vegetation cover. Charcoal recovered from soil-depth profiles is interpreted as evidence of local fires, but is not necessarily representative of in situ burning, since some charcoal was probably deposited as midden material.

A forested environment, or a closed canopy environment, may be represented by an arboreal forest, a palm forest or a mixed arboreal/palm forest. In terms of pollen, canopy cover is taken as the sum of arboreal and palm taxa. In relation to phytoliths, we estimate that percentages of canopy cover phytoliths (the sum of arboreal and palm) greater than 35\% represent a closed canopy forest (see Supplemental Text 2).

\subsection{Results}

\subsubsection{Canopy cover}

5.2.1.1. Pollen from lake records. In the Caranã pollen record, arboreal taxa including palms represent $>90 \%$ across the sequence, which is paralleled by $>85 \%$ arboreal phytoliths in the soil profiles of nearby ADE (Maguari STP 1, 2 and 3) (Fig. 8). In the Versalles pollen record, arboreal taxa including palms represent $>75 \%$ across the sequence, which is also paralleled by arboreal phytoliths averaging 76.9\% (52.4-92.1\%) and 76.4\% (49.8-98.1\%) from Triunfo ADE and $\mathrm{ABE}$, respectively (Fig. 9).

5.2.1.2. Phytoliths from soil profiles. Collectively, all 23 profiles (285 samples) represent closed canopy, with $93 \%$ of the samples composed of $>50 \%$ closed canopy phytoliths (palm and arboreal summed). All but one of the 285 samples represent $>35 \%$ canopy cover, which is our baseline for interpreting closed canopy. The patterns from the 23 profiles across the ten sites are mostly dominated by arboreal canopies (16/23 profiles) while showing some differences (Figs. 5-7; Supplemental Tables 2, 4, 6). The profiles located on ADE and ABE soils are dominated by phytolith morphotypes corresponding to 'other arboreal' (all arboreal types excluding palms, hereafter referred to as arboreal). The heterogeneity in the vegetation patterns comes from variations in percentages of palms and grasses/herbs. Nine of the profiles are arboreal dominant with $>40 \%$ arboreal phytoliths, three profiles comprise $>50 \%$ arboreal phytoliths and four have $>60 \%$ arboreal phytoliths (Supplemental Tables 2, 4, 6). Two profiles (Belterra and one from Teotônio) are dominated by palms; Belterra contains $>30 \%$ palm and Teotônio (N9877 E10022) exhibits $>40 \%$ palm. The remaining five profiles have vegetation patterns that although are predominantly closed canopy, exhibit significant change in vegetation throughout the profiles (Maguari SP3, Teotônio P1, Teotônio (N10049 E99565), Caldeirão P2 and Santa Paula, see Supplemental Tables 2, 4, 6).

$A D E$ soil profiles. All ADE profiles contain closed canopy cover phytoliths $>35 \%$. Canopy cover phytolith percentages can be summarised as follows: three of the profiles $>80 \%$ (Teotônio P1, Caldeirão P1, P2), three $>70 \%$ (Teotônio N9882 E10022, Maguari SP1, Couro Velho P5), two >60\% (Teotônio N9882 E10022, Couro Velho P7), three $>50 \%$ (Triunfo, Trevisan, Porto), two $>40 \%$ canopy cover (Santa Paula, Teotônio N10049 E9965) (see Figs. 5-7; Supplemental Tables 2, 4, 6). The remaining ADE from Belterra is
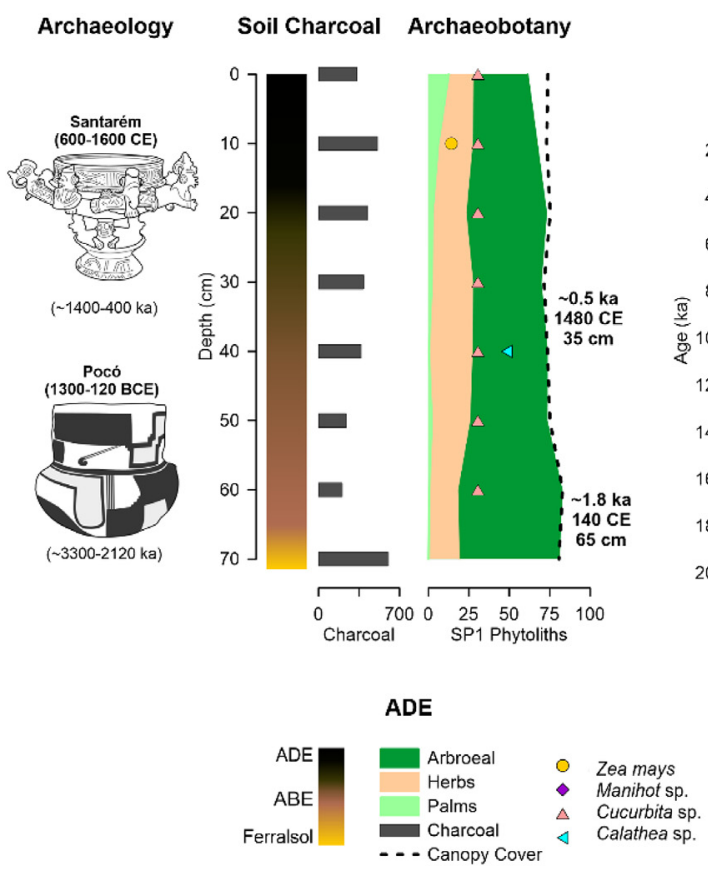
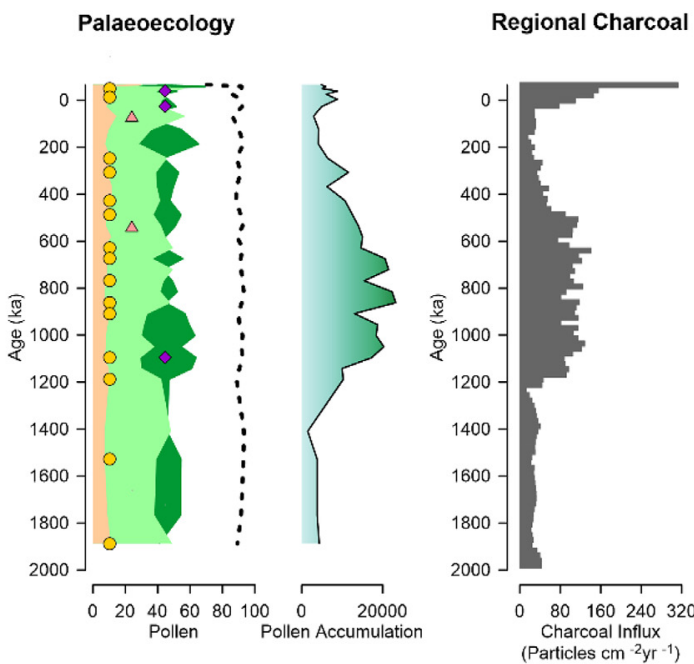

Palaeoclimate

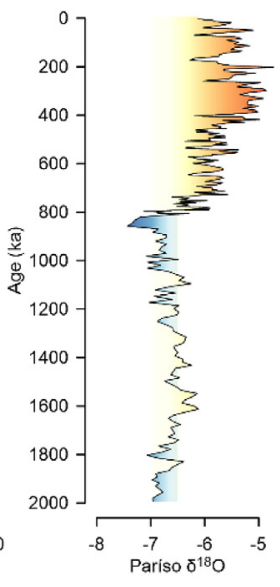

Fig. 8. Compiled data summary for Serra do Maguari ADE - Caranã Lake. 

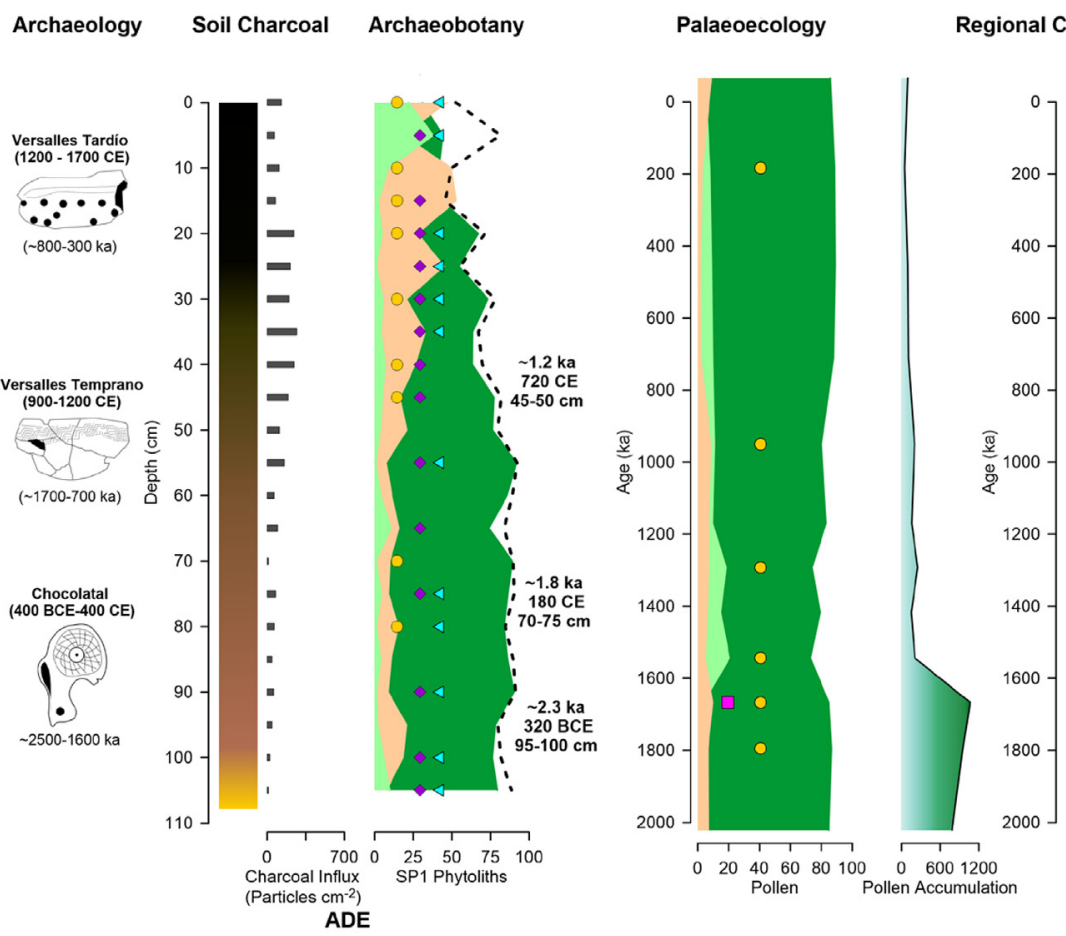

Charcoal

Regional Archaeology

Palaeoclimate
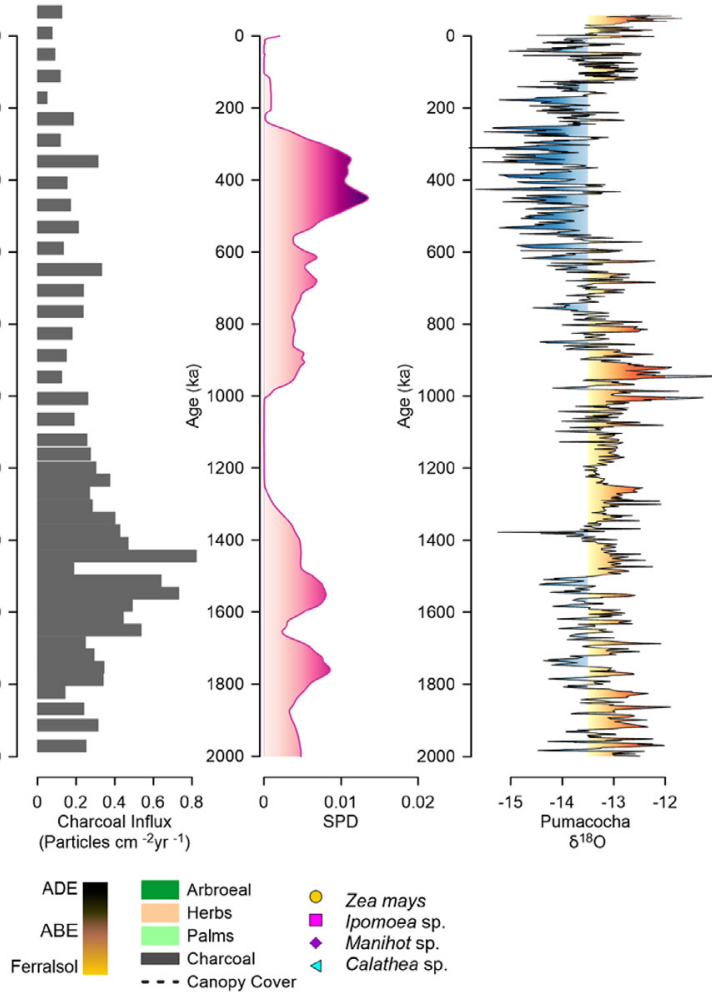

Fig. 9. Compiled data summary for Triunfo ADE - Versalles Lake.

divided into three stratigraphic layers/samples $(0-35 \mathrm{~cm}$, $35-70 \mathrm{~cm}, 70-165 \mathrm{~cm}$ ). The upper two layers contain $>60 \%$ canopy indicator phytoliths and the 70-165 cm layer has 36\% phytoliths representing canopy indicators (see SI). Eight ADE profiles are closed canopy dominated by arboreal phytoliths (excluding palms): four with $>40 \%$ (Trevisan, Porto, Triunfo, Teotônio N9882 E10022), two with $>50 \%$ (Couro Velho P7, Caldeirão P1) and two with $>60 \%$ (Couro Velho P5, Maguari SP1) (see Figs. 4-6. Supplemental Tables 2, 4,6). The remaining five profiles maintain closed canopy phytolith percentages but experience significant vegetation changes throughout the profiles (Maguari SP3, Teotônio P1, Caldeirão P2, Teotônio (N10049 E99565), Santa Paula) (see Figs. 5-7; Supplemental Table 4).

$A B E$ soil profiles. All nine $A B E$ profiles included in this analysis exhibit closed canopy cover phytoliths $>35 \%$. Three profiles have closed canopy cover phytoliths $>70 \%$ (Couro Velho P1, P2, Maguari SP3), one profile $>60 \%$ (Maguari SP2), two profiles $>50 \%$ (Triunfo, Cedro SP2), while the remaining three ABE profiles have closed canopy cover phytoliths representing $>40 \%$ (Cedro SP3, 4 and 5) (Figs. 5-7; Supplemental Tables 2, 4, 6). Eight of the ABE profiles are closed canopy dominated by arboreal phytoliths: five profiles with $>40 \%$ arboreal (Cedro SP2, 3, 45 and Triunfo), one with $>50 \%$ (Maguari SP2), and two with $>60 \%$ (Couro Velho P2, Couro Velho P1) (see Figs. 5-7; Supplemental Tables 2, 4, 6). The last ABE profile (Maguari SP3) remains closed canopy throughout, but has significant vegetation changes across the profile, with transitions from arboreal dominated in the lower layers to a predominance of mixed arboreal/palm in the upper layers (see Supplemental Tables 2, 4, 6).

\subsubsection{Annual crop}

5.2.2.1. Pollen from lake records. At Lake Caranã, maize is present at $\sim 4.5 \mathrm{ka}$, sweet potato $\sim 3.3 \mathrm{ka}$, manioc $\sim 2.3 \mathrm{ka}$, and squash $\sim 0.4 \mathrm{ka}$
(Fig. 8). In Lake Versalles, next to the Triunfo site, maize is present at $\sim 4.5 \mathrm{ka}$ and sweet potato $\sim 1.7 \mathrm{ka}$ (Fig. 9). Our data indicate that maize was initially cultivated along the shores of these lakes and only with the development of human-enriched ADE soils could it be cultivated in terra firme locations.

5.2.2.2. Phytoliths from soil profiles. Collectively, out of the 23 profiles included in this analysis, 18 contain a diversity of crop phytoliths including Cucurbita sp. (12), Zea mays (11), Manihot sp. (5), Maranta sp. (9) and Calathea sp. (13). Maize has been identified at Maguari, Couro Velho, Porto, Cedro, Triunfo, Santa Paula, and Teotônio sites. Manihot sp. was documented at Triunfo, Trevisan and Teotônio. Leren (Calathea sp.) has been identified at Teotônio, Triunfo, Couro Velho, Maguari, Cedro and Porto. Squash (Cucurbita sp.) is present in Couro Velho, Porto, Maguari, Cedro, Trevisan and Teotônio sites. Maranta sp. has been identified at Teotônio, Santa Paula, Couro Velho and Cedro. In addition to Cucurbita sp., Zea mays, Manihot sp., Maranta sp. and Calathea sp., there are a range of phytoliths identified corresponding to edible plants, including: palms (all sites), Olyreae (Triunfo, Teotônio, Trevisan, Couro Velho, Maguari, Cedro and Porto), Celtis sp. (Triunfo, Trevisan, Couro Velho, Maguari, Cedro and Porto), Chusquea sp. (Triunfo and Teotônio) and Pharus sp. (Maguari, Cedro, Porto) (Supplemental Table 3). No crops were identified in ADEs at Belterra (Kondo and Iwasa, 1981) and Caldeirão (Macedo, 2014), but when these analyses were done the phytolith techniques for identifying these crops were not developed or were not applied by the phytolith analysts.

ADE soil profiles. Ten of 14 ADE profiles contain crop phytoliths including maize (Triunfo, Teotônio, Santa Paula, Couro Velho, Maguari, Porto), Manihot sp. (Triunfo, Teotônio, Trevisan), Cucurbita sp. (Teotônio, Trevisan, Couro Velho, Maguari, Porto), Calathea sp. 
(Teotônio, Triunfo, Couro Velho, Maguari, Porto), Maranta sp. (Teotônio, Santa Paula, Couro Velho) (Supplemental Table 5).

$A B E$ soil profiles. Eight of nine ABE profiles contain crop phytoliths. The following crop phytoliths were identified at ABEs: Zea mays (Maguari, Triunfo, Cedro), Manihot sp. (Triunfo) Cucurbita sp. (Couro Velho, Maguari, Cedro), Calathea sp. (Triunfo, Couro Velho, Maguari, Cedro) and Maranta sp. (Couro Velho, Cedro) (Supplemental Table 3).

\subsubsection{Enrichment of the forest with plants of economic importance}

Pollen from the lake records. The lake record of Caranã is characterised by an increase in the number of edible plants (from $45 \%$ to $>70 \%$ of terrestrial pollen taxa), a decrease in the number of nonedible plants (from $~ 50 \%$ to $30 \%$ ), followed by the arrival of manioc Manihot sp. 2,250ka (Fig. 8). The increase in the number of edible plants is not associated with significant change in the regional climate data, suggesting that pre-Columbian forest enrichment is the driver of this abrupt change in forest composition. A similar trend is seen in at the Versalles Lake core during the late Holocene. The increase in Attalea pollen $\sim 1.5 \mathrm{ka}$ clearly shows that the presence of palm dominated forest, at least in this part of SW Amazonia, is not a modern development but a clear legacy of pre-Columbian phenomena (Fig. 9) (Maezumi et al. in prep).

This trend is paralleled by phytolith data from nearly all profiles in other archaeological sites, indicating a gradual increase in Arecaceae and Celtis sp. in 16 of 23 profiles. Four profiles exhibit fairly consistent values representing forest enrichment (two from Cedro and two from Teotônio) and the remaining three exhibit a slight decrease in forest enrichment phytoliths (Porto, Teotônio N9882 E10022, Cedro Test Pit 2) (Figs. 5-7).

5.2.3.1. Phytoliths from soil profiles. ADE soil profiles. Thirteen of the 14 ADE profiles have significant if not prevalent Arecaceae (not including Maguari Test Pit 1). In 10 ADE profiles there is a gradual increase in forest enrichment from Triunfo, Belterra, Maguari, Couro Velho, Trevisan, Caldeirão, Santa Paula and Teotônio (although at the latter site, Arecaceae do not consistently increase throughout the whole of the site, depending on profile location). Five of the 10 profiles include low percentages of Celtis sp. (Figs. 5-7; Supplemental Table 6).

$A B E$ soil profiles. Percentages of Arecaceae are lower in the ABE profiles, with less significance than in ADE profiles. Six of the profiles do see a gradual trend towards increasing Arecaceae (Triunfo ABE, Maguari Test pit 2, Maguari Test Pit 3, Cedro Test Pit 5, Couro Velho CAST 1 (P1) and Couro Velho CAST 2 (P2)). Four of these profiles have low percentages of Celtis sp. (Figs. 5-7; Supplemental Table 6).

\subsubsection{Fire regimes}

5.2.4.1. Charcoal from the lake records. Lake Caranã exhibited an increase in fire activity $\sim 1.25-0.5 \mathrm{ka}$ associated with the formation of ADE (SP1) and an increase in pre-Columbian activity (as shown by the summed probability distributions (SPDs) of radiocarbon dates diagram)) (Fig. 8). The decrease of fire activity does not indicate the abandonment of the region related to the $\mathrm{CE}$, since available data show that the region was populated until the 1700 s. The decrease is not related to climate since this is one of the driest peaks of drought in the region. It is related either to the abandonment of the region (not supported by SPDs) or to a change in land use practices, such as controlled fires. At Lake Triunfo, the formation of ADE starts $\sim 2.4 \mathrm{ka}$. Charcoal influx peaks before the emergence of $\mathrm{ADE}$ followed by a general decrease (with minor fluctuations) until the present (Fig. 9). Unlike Lake Caranã where fire activity remained high for $\sim 1000$ years of ADE occupation, Lake
Triunfo shows a rather steady decline until the present. The initial peaks may correspond to the large fires that led to the creation of $\mathrm{ADE}$, while the decreasing trend reflects the controlled fires associated with ADE use.

5.2.4.2. Charcoal from soil profiles. Twelve of the PAST project soil profiles were systematically counted for macroscopic charcoal. While there are fluctuations there is a general trend towards increased charcoal throughout all of these profiles, generally occurring at the transition from 'ferralsol' to ADE or ABE, thus corroborating the formative role that fire plays in $\mathrm{ADE}$ formation (see Figs. 5-7; Supplemental Table 6).

5.2.4.3. ADE soil profiles. Four ADE profiles were counted for charcoal (Triunfo, Couro Velho, Maguari and Porto). Three of these profiles (Triunfo, Couro Velho, Porto) exhibit a significant increase in charcoal throughout the profiles. Charcoal fragments in the ferralsol at Triunfo average 18 per sample, but in the ADE average 122 per sample. At Couro Velho (TP 1 P5) the average charcoal count in ferralsol samples is 4 and in the ADE 272 fragments. At Porto there are no samples from the ferralsol, but the deeper and slightly lighter deposits (60-125 cm below surface (b.s.) average 190 fragments, while the upper darkest deposits $(0-55 \mathrm{~cm}$ b.s.) average 508 charcoal fragments per sample. In contrast, the deepest sample in the ferralsol of the ADE profile from Maguari (test pit 1) has 602 charcoal fragments while the average in the ADE is 352 fragments (Figs. 5-7).

5.2.4.4. ABE soil profiles. Eight ABE profiles were counted for charcoal (Triunfo, Couro Velho, Maguari (2), Cedro (4)). All profiles exhibit a significant increase in charcoal throughout. At Triunfo the ferralsol samples average 74 charcoal fragments while the ABE samples average 101 fragments. At Couro Velho (CAST 1 P2) the ferralsol samples average 12 charcoal fragments and ABE samples 92 fragments. At Maguari two profiles were analysed for macroscopic charcoal, test pits 2 and 3, the ferralsol samples averaging 331 and 291 charcoal fragments respectively, and the ABE samples 1153 and 987. All four ABE profiles from Cedro were counted for charcoal fragments (test pits 2, 3, 4 and 5); the ferralsol averages are 178, 89, 79 and 63. The ABE averages for Cedro are 868, 970, 594, 899 (test pits 2, 3, 4 and 5 respectively) (Figs. 5-7).

\subsubsection{Summary of results}

Canopy cover. Profiles located on Amazonian anthrosols across southwestern, central and eastern Amazonia exhibit an overall average of $62 \%$ canopy cover phytoliths. Within this general homogenous pattern of closed canopy forest, there are variations in the proportions of palms, grasses, herbs and crops. The overall land cover pattern on $\mathrm{ADE}$ and $\mathrm{ABE}$ does suggest a similar signature for ADE systems across Amazonia, regardless of the regional cultural, bio-geographic and climatic variations in site location. The results do not suggest that ADE localities were wholesale cleared and kept open for the cultivation of annual crops, but rather points to the practice of polyculture agroforestry characterised by a mosaic of patches in different stages of succession, forming a complex landscape that transitions from forest to field and back to forest again (see Supplemental Text 3).

Annual crops. The archaeobotanical and palaeoecological data indicate that during the late Holocene Amazonian people practised mixed cropping on these anthrosols, as evidenced by the presence of several annual and perennial crops including maize, manioc, sweet potato, squash, arrowroot, and leren. To what extent some of these crops become a staple in the diet of specific population groups is a difficult question to answer with the data at hand. At 
Teotônio, a large increase in recovery of maize phytoliths at the expense of other crops accompanies darker ADE deposits formed by the carriers of Jamari phase ceramics. Maize is also the most abundant starch grain recovered in these ceramics, which are clearly utilitarian, and suggests that this species may have briefly become a staple at the site (Watling et al., 2020b). In the overlying ADE deposits containing Jatuarana ceramics, maize decreases and quartz flakes containing manioc, sweet potato and yam starch grains suggest an increased focus on these tuber crops (Watling et al., 2020b). Unfortunately, the presence of microfossils in soil profiles and lake sediments does not tell us the proportion of diet these crops constituted, and no skeletal remains were recovered in the excavations carried out in these regions to conduct stable carbon and nitrogen isotopes to assess the weight of maize in these pre-Columbian diets. The presence of maize in the archaeobotanical evidence from eastern Amazonia is congruent with early historical accounts describing maize as the staple food for the populations living in the confluence of the Tapajós and Amazon rivers during early post-Columbian times (Heriarte, 1874 [1662]).

Enrichment of forest with edible plants. Both the terrestrial soil profiles and the lake records are characterised by an increase in the number of edible plants and a decrease in the number of non-edible plants. In each region where we have high-resolution local palaeoclimate records, the increase in the number of edible plants is not associated with significant change in the regional climate data, suggesting that these changes in forest composition are human driven. For example, we see at one site a dominance of palm over broadleaf forest, and at other sites increasing palms; however, some sites show only a recent increase in palm in the upper $20 \mathrm{~cm}$ b.s. (e.g., Triunfo). Many of these synchronic and diachronic changes in palm phytolith abundance in ADEs may also be heavily affected by activity areas within the archaeological sites. Palms are the de facto construction material of choice for Amazonian peoples (Balick, 1984), and the decomposition of houses within villages should be considered a primary source for palm phytoliths (Watling et al., 2020b; Watling et al., 2018). Increased densities of both useful and non-useful palm species have been reported in modern floristic inventories of $\mathrm{ADE}$ in comparison with non-ADE sites (see above). Importantly, the pollen record shows a sharp increase $\sim 1.5 \mathrm{ka}$ in Attalea palm, the predominant palm growing today in ADE around Versalles, demonstrating that its dominance in ADE forest in this region is not the result of modern historic management, but represents a deeper pre-Columbian legacy. The increase in palms over the late pre-Columbian period to historic times is reflected in the floristic inventories that show palms are predominant in today's ADE vegetation across the basin (e.g., Junqueira et al., 2011; Lins et al., 2015). Increases in the abundance of palms have also been recorded in a non-ADE geoglyph transect in the neighbouring Brazilian state of Acre during the Holocene when human activities intensified (Watling et al., 2017). Similar findings have been documented in other neotropical regions, like the Maya area of Belize, where Rushton et al. (2013) show evidence of palm monoculture at the height of the Classic period.

Fires. Clearance and burning do seem to have played a role in the establishment of ADEs, with later fire management suppressing larger wildfires. Soil-depth ADE and ABE profiles show a general increase in charcoal counts over time, with drastic charcoal increases at the onset of anthropogenic soil development. The lake charcoal records show charcoal peaks correlated with the development of ADEs followed by stagnation (Caranã) or decline (Versalles). These charcoal records suggest that controlled in-field burning was likely practised in these fields to clear weeds, release nutrients and contribute to anthropogenic pedogenesis once ADE was established.

\section{Discussion and conclusions}

\subsection{Late Pleistocene to middle Holocene}

A schematic summary of major development in Amazonian history is depicted in Fig. 10. Our review shows that rather than the traditional portrait of a big-game hunting narrow-spectrum foraging diet, the earliest settlers of the Amazon based their subsistence on a broad-spectrum diet of tropical roots and tubers, tree and palm fruits and nuts, as well as many medicinal/narcotic plants, along with hunting and foraging for terrestrial and riverine fauna. Productive ecotones, in particular palm-dominated tropical forestsavannah-riverine mosaics, likely attracted these early foragers for the establishment of temporary or semi-permanent camps. An important number of these plants consumed since the late Pleistocene to early Holocene transition continued to be prevalent in historic times, many becoming hyperdominant. Mounting evidence also shows that plant cultivation not only emerged in savannahs and seasonal forest in SW Amazonia, but also evolved in the montane forests of NW Amazonia. Forest-savannah ecotones like the Llanos de Mojos and localities with palm dominated forests such as Monte Alegre and La Lindosa appear to have provided ideal settings for these early colonisers. Recent data from the Llanos de Mojos show that along with the beginnings of plant cultivation, the early settlers created thousands of forest islands while managing savannah landscapes. Through these practices, communities increased resource abundance and heterogeneity for humans and animals, underscoring the strong relationship between plant and landscape domestication and the significant human footprint on Amazonian environments. Radiocarbon data suggests that the middle Holocene shows an overall decline in population; however, new and renewed research regions across Amazonia is slowly beginning to fill the gap of information. Importantly, the middle Holocene witnessed the domestication of important crops such as cacao and the spread of Amazonian domesticates like manioc, as well as the arrival and spread of exotic cultigens like maize. As food production became more important during the middle Holocene, the extent and pace of landscape modification increased, culminating in the major transformations that took place during the late Holocene, which in turn likely generated a positive feedback on population growth as seen in the radiocarbon databases (ArroyoKalin and Riris, 2020; de Souza et al., 2019a).

\subsection{The late Holocene}

During the late Holocene, Amazon people began to invest in the landscape and develop intensive systems of food production. Millions of hectares of seasonally-flooded savannahs were reclaimed as raised field agricultural landscapes, and the widespread dispersal of Amazonian anthrosols began.

Amazonian anthrosols as intensive agroecosystems. The archaeobotanical data presented in this article, along with soil science and micromorphology, indicate that $\mathrm{ABE}$ anthrosols were fields where spatially intensive (high labour input/unit area) cultivation, relying on organic amendments and likely requiring soil preparation and maintenance, took place. Data show the cultivation of both annual and perennial crops. Since a large portion of the perennial tree fruits and palms are not amenable to an increase in fruit size even under intensive management, in order to achieve greater yields Amazonian farmers likely increased the density of trees on the land by creating favoured ABEs habitats. ABEs represent an investment in the land as well as in the labour required to cultivate trees needing management practices (e.g., weeding, cleaning of undergrowth) with long productive cycles. For example, Brazil nut and pequi only start producing after several years, sometimes decades, 


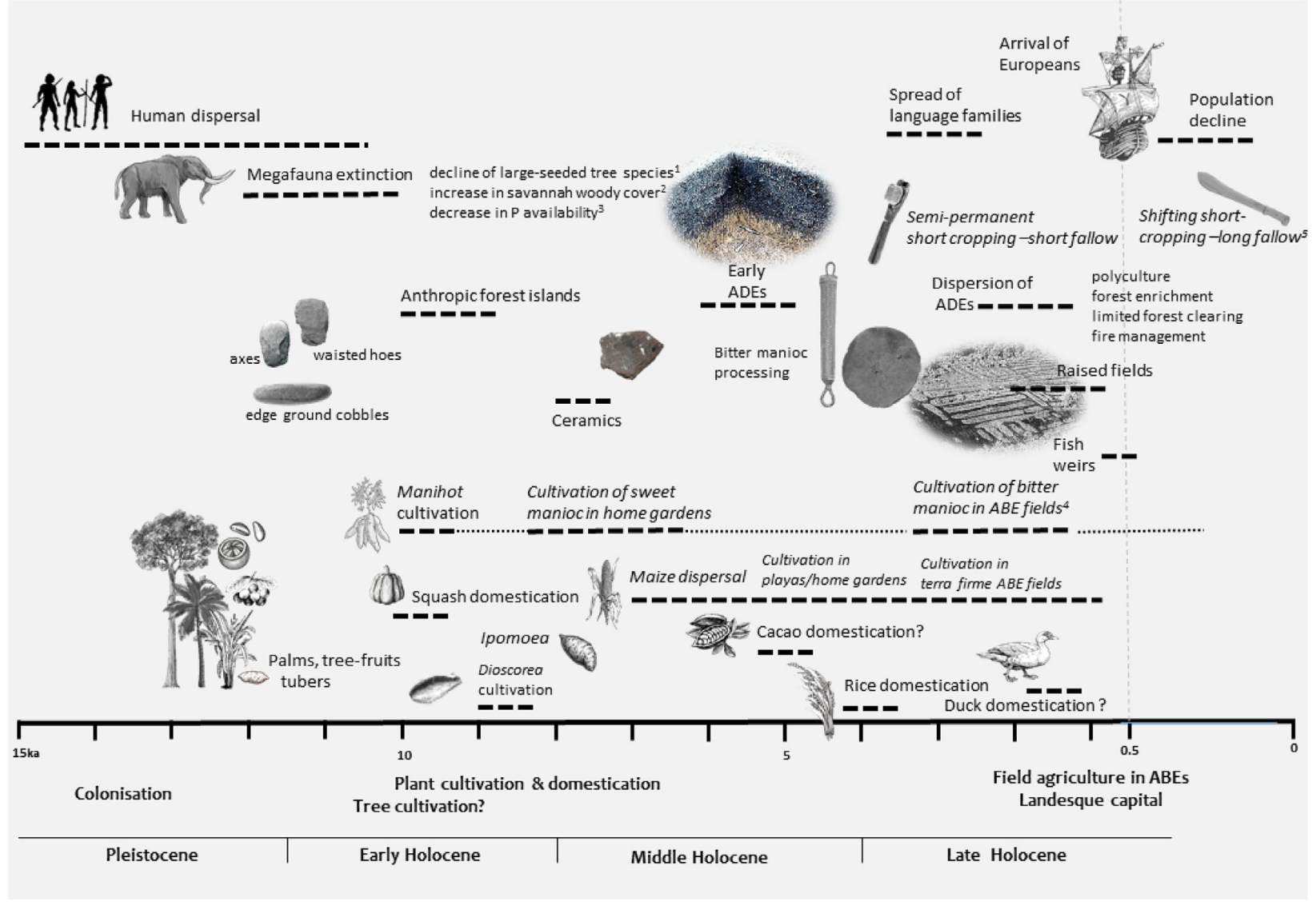

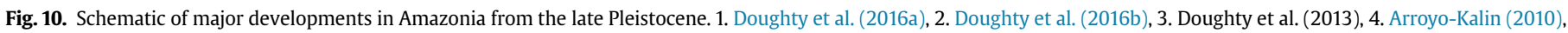
5. Denevan (2004).

but then remain productive for up to centuries (Scoles and Gribel, 2011; Shepard and Ramirez, 2011; Smith and Fausto, 2016). This not only happened in Amazonia; Robinson et al. (2018), for example, have documented the afforestation of entire landscapes in south-eastern Brazil with forests of Araucaria, which only become productive after 17-21 years (Mattos, 1972).

Our data indicate that Amazonian polyculture agroforestry systems maintained a canopy cover. These findings accord with pollen records from the wet forests of W Amazonia in Peru on ADE sites (Kelly et al., 2018), the phytolith records from interfluvial areas (McMichael et al., 2012) and archaeobiological data from the late Holocene western coastal Ecuador Jama-Coque II cultures, which all suggest agroforestry land use combining annual, perennial tree crops and useful forest taxa (Stahl and Pearsall, 2012). However, our findings contrast with the records of the Colombian Amazonian ADEs at the Meidote phase of the Abeja site (1.6-0.8ka), whose pollen record shows high forest disturbance frequencies suggesting that the area around the site was widely cleared for agriculture (Mora et al., 1991). Our records also contrast with evidence for increased forest burning and clearing, maize cultivation and erosion in the Maya lowlands at the start of the middle Holocene 4.5-4.0ka (Pohl et al., 1996; Wahl et al., 2006) and are markedly different from the Mediterranean and temperate regions of Europe, where the spread of agriculture was accompanied by deforestation (Roberts et al., 2018). Our results show that in Amazonia there was no significant reduction in forest cover.

Amazonian anthrosols are extremely fertile, but experiments show that weeds grow five times faster than in non-anthropic soils (Major et al., 2005). Therefore, although they are exceptionally productive, they do require a lot of maintenance labour. This is corroborated by ethnographic evidence by Carneiro (1960), who showed that the Kuikuru Indians in the upper Xingu River do not abandon fields due to declining soil fertility but because of a lack of labour to clear invading weeds. The high labour investment involved in ABEs was noted by Denevan (2004), who maintained that the cultivation of ABEs must have required high labour inputs, in particular for controlling weeds, which are more aggressive in areas of intensive cultivation than in clearings from mature fallows or primary forest. Based on observations of ADE farmers today in Brazil, who rotate crops with a few years of bush fallow as an effective way of reducing the labour cost of weeding (German, 2003), Denevan (2004) suggests that ABEs were cultivated semipermanently rather than permanently. ABEs as permanent fields with large investments of labour are difficult to imagine in the ethnographic present, but not in pre-Columbian Amazonia before the decimation of agricultural populations. Therefore, we suggest that ADE agroecosystems were likely labour-demanding but highly productive, integrating annual and perennial crops that along with faunal resources were able to sustain the large populations that developed during the late Holocene and were observed by the first Europeans in the Amazon. As spatially intensive and highly fertile settings, ABEs should be regarded as tangible evidence of increased productivity per unit of land. Amazonian anthrosols, in particular the creation of ABEs and agroforestry, represent investment in landesque capital that could be considered a technology of soil enhancement to increase productivity in upland settings (Erickson, 2008; Myers, 2004). ABEs represent an investment for the cultivation of root and seed annual crops, which are ready to be 
harvested several months after planting, while managed orchards for agroforestry represent a long-term investment of labour. The functional integration of ABE cultivation and duck husbandry as 'pest control' is an intriguing possibility, at least for the southern rim of the Amazon, where it has been documented both historically and archaeologically.

The role of maize and manioc. Interestingly, our data indicate that maize either appears or becomes more dominant only after the development of Amazonian anthrosols. The development of ABEs may have allowed for the expansion of the cultivation of this productive crop beyond lake margins, which probably increased the carrying capacity of the land to sustain the large populations observed in the population growth trends using radiocarbon databases (Arroyo-Kalin and Riris, 2020). While maize likely played a supplemental role during its adoption and dispersal during the middle Holocene, it likely became a more important part of the diet with the development of Amazonian anthrosol agriculture. This increase during the late Holocene is supported by other lines of evidence. The isotopic composition of human bones from some regions of the Amazon, including the middle Orinoco River $400 \mathrm{CE}$ (van der Merwe et al., 1981), the Upper Ucayali (Roosevelt, 1989) and the Llanos de Mojos (Prümers and Jaimes Betancourt, 2014) shows a progressive increase in a maize-based diet. Similarly, in the central Amazon, carbon and nitrogen stable isotopes from human bones associated with the formation of anthropogenic dark earths suggest a 'maize-existing but not maize-reliant diet' (Arroyo-Kalin, 2008). Isotopic analyses from skeletal remains pertaining to the Maraca tradition from the mouth of the Amazon, dating to $\sim 0.5 \mathrm{ka}$, indicate that these populations had diets based on the exploitation of fish and a wide range of C3 plant resources, with maize not a significant component (Hermenegildo et al., 2017). The Marajoara cultural tradition (400-1300 CE) does not appear to be based on a maize economy, though paradoxically isotope data from skeletons dated to the last centuries before European colonisation show a strong C4 signature (Roosevelt, 1991). Changes in diet as evidenced in human bone isotopes appear to be reflected in changes in material culture in some regions. The budares used to process bitter manioc are replaced by manos and metates employed to process maize grain in the middle Orinoco River $\sim 2.7 \mathrm{k}$ (Roosevelt, 1987b), the Caribbean littoral of western Venezuela $\sim 3-2 \mathrm{k}$ (Rouse and Cruxent, 1963), and at Caverna da Pedra Pintada 3-2k (Roosevelt et al., 1996). A compilation of palaeoecological and archaeobotanical data from raised fields across tropical SA also shows that maize was an important crop in this late Holocene agricultural system (Iriarte and Dickau, 2012).

Manioc is arguably the most important root crop in the tropics (Scott et al., 2000). It has a high starch content, great productivity and an ability to grow in less than optimal soils (but also highly productive in ADEs). Bitter varieties are pest resistant. It can be stored in the ground for up to six months, while the different forms of flour can be stored for more than a year. The weight of manioc in late Pre-Columbian diets remains unresolved. However, several lines of evidence points to its importance in late Holocene Amazonian economies: (i) presence of Manihot sp. phytoliths and pollen in Amazonian anthrosols and nearby lakes, (ii) appearance of bitter manioc-processing material culture during the late Holocene, and (iii) the hundreds of varieties created by Amazonian farmers since their initial cultivation in the very early Holocene. Manioc may indeed have been a part of pre-Columbian land use systems (polyculture agroforestry with stone axes) very different to postColumbian practices (slash-and-burn with metal axes). However, it cannot be said for certain that manioc was less prominent in preColumbian Amazonian diets, as has been recently asserted by some authors (Fausto and Neves, 2018; Shepard et al., 2020). Until we have more sophisticated techniques to document the importance of manioc in late Holocene Amazonian societies, claims that manioc was not an important crop should be taken with caution (Fausto and Neves, 2018; Shepard et al., 2020). Similarly, uncertainty exists about the extent to which bitter manioc replaced sweet manioc during the middle Holocene - late Holocene (Arroyo-Kalin, 2010), and whether manioc progressively replaced other tubers in preColumbian times (Piperno and Pearsall, 1998). These are all important questions that will not be easily resolved.

Our summary and new data do not support claims that the late Holocene agricultural systems were characterised by opportunist agroforestry (Fausto and Neves, 2018; Neves, 2007) similar to those described in historic or modern ethnographic settings. We would argue that regardless of what we choose to call these societies for analytical purposes, characterising them as opportunistic agroforesters and downplaying the role of intensive agroforestry systems is inappropriate. As several students of Amazonian agriculture have pointed out, plant domestication and the development of agriculture needs to be studied 'on its own terms'. These processes followed a trajectory different from the Eurasian experience. However, all evidence point to the fact that some late Holocene agricultural systems, such as Amazonian anthrosols, were intensive across Amazonia. The process could be reversible in the ethnographic present (Balée, 1994; Cunha, 2019; Fausto, 2001), and could have been so in pre-Columbian times. Our data do not suggest Amazonia was the Neolithic that never happened (Fausto and Neves, 2018). The several lines of evidence presented in this article, along with the first eye witness accounts along the Amazon and its upland forests, show that in many regions Amazonian societies became numerous and socially complex, investing in the landscape and practising intensive systems of land use that were resilient to climate change. Furthermore, our synthesis and new data show that the plant and landscape domestication across Amazonia that began in the early Holocene is similar to that in other tropical and subtropical regions across the world and ultimately constituted the economic basis for population expansion and social complexity. The larger regional populations currently being documented by archaeology across Amazonia, many of whom relied on polyculture agroforestry systems supported by intensive cultivation in Amazonian anthrosols, fall well into the range of medium-sized pre-Columbian polities elsewhere in the Americas, as well as the range of medium-sized pre-modern urbanised forested landscapes in most world areas (Clement et al., 2015; Heckenberger et al., 2008; Roberts, 2019).

\subsection{Implications for sustainable Amazonian futures}

The Amazon forest is the largest reservoir of biodiversity in the world and is of crucial importance for the regulation of Earth's climate. By $2050,50 \%$ of the global population will live in the tropics, and over $90 \%$ of the world's poorest people depend on forests for earning their livelihoods and preserving their culture (State of the Tropics, 2050). The protection of rainforests and the development of sustainable land use practices are of global significance, but increasing challenges from economic demands, commercial interests, population growth and climate change are threatening traditional indigenous identities and Amazonian biodiversity. While the existence of indigenous lands is currently the most important barrier to Amazonian deforestation (Nepstad et al., 2006), indigenous and traditional communities living in the Amazon, in many instances encouraged by modern states, are increasingly converting to cattle ranching and commercial slash- 
and-burn agriculture for the potential economic rewards and because of the lack of alternative economic pathways. This is leading to widespread deforestation and is having a dramatic impact on community identity. Developing alternative economic avenues is key for Amazonian futures and to meet UN Sustainable Development Goals.

Our results indicate that through soil fertilisation, closedcanopy forest enrichment, limited clearing for crop cultivation and low-severity fire management, long-term food security and nutritional diversity was attained. This land use system supported larger populations and was resilient to climate change and broad social upheaval. These millennial-scale polyculture agroforestry systems have an enduring legacy on persisting patches of highly fertile soil and on the modern composition of the forest, including legacy plots of cacao, Brazil nut, and palm. These systems not only provide evidence of successful, sustainable subsistence strategies that conserve agrobiodiversity (Junqueira et al., 2010) but also highlight a rich cultural-ecological heritage. The results provide scientifically grounded data that can address the modern challenges faced by the rainforest and its marginalised indigenous inhabitants who still harbour and utilise much of this ecological knowledge accumulated over millennia.

\subsection{Future directions: Tasks and challenges ahead}

First and foremost, there is still a considerable need for intensive primary data collection across the basin for the different time periods. This is particularly acute for the Western Amazon. Levis et al. (2017) show that the richness and abundance of domesticated tree species and palms increased in the vicinity of archaeological sites, but importantly, was often great along major and tributary rivers without known archaeological sites. Indeed, these apparently vacant regions in our maps represent important opportunities for future research (Clement et al., 2015; Levis et al., 2017, 2018). Research programmes should strive for increasing integration of interdisciplinary, complementary multi-proxy approaches and techniques combining archaeology, palaeoecology, paleoclimate, soil science, remote sensing and floristic inventories. Sample selection should include random locations as well as sites deliberately located either close to or far from archaeological sites. Accurate evaluation of the legacy of past indigenous people within current ecosystems can only be provided by appropriate research designs that integrate the long-term data from fossil records with the modern information provided by botanical inventories. This can help resolve the question of whether current vegetation derives from pre-Columbian activities or is the result of more recent historical land transformations (Junqueira et al., 2017; McMichael et al., 2017). As suggested by Dick and Pennington (2019) detailed phylogeographic and population genetic studies of widespread species would be powerful tools for testing whether widespread distributions pre-dated human influences.

Although an ever-growing number of important ecologically and economically important plant taxa are identifiable to the genus level in pollen, phytolith, and charcoal analyses, taxonomic resolution needs further refinement to resolve long-standing issues. More work along the lines of Whitney et al. (2019) to quantify the spatial scale of pollen and charcoal production and deposition are sorely needed. Although there has been considerable progress towards the creation of modern analogue pollen and phytolith assemblages from 'natural' vegetation formations, very little has been done to further our understanding of modern analogues for traditional Amazonian land use systems. Similarly, unlike in Europe and Asia where significant advances have been made towards identifying modern analogues of macrobotanical remains and phytolith assemblages of weeds associated with crops, to reveal specific agricultural practices (e.g., Bates et al., 2017; Weisskopf et al., 2015; Willcox, 2012), so far no progress has been made in the neotropics. Another major task ahead is to establish the phenotypic and genetic characterisation of perennial tree fruits to distinguish more precisely different degrees of morphogenetic modification. Molecular studies will continue to help clarify the genetic changes that constitute the domestication syndromes of crops. Last but not least, it is time to begin unpacking Amazonia to apprehend the whole diversity of land use systems across the basin and in different periods. As we acquire more detailed data from a particular region it is becoming apparent how inappropriate it could be to extrapolate sub-regional data to the entire Amazon basin.

\section{Declaration of competing interest}

The authors declare that they have no known competing financial interests or personal relationships that could have appeared to influence the work reported in this paper.

\section{Acknowledgements}

This work was funded by the ERC. Funding for this research was supported by the PAST (Pre-Columbian Amazon-Scale Transformations) European Research Council Consolidator Grant to J.I. (ERC_Cog616179) and the LASTJOURNEY (The End of the Journey: The Late PleistoceneEarly Holocene Colonisation of South America) European Research Council Advanced Grant to J.I (ERC_Adv834514). Research at Teotônio and Santa Paula by Watling and collaborators was funded by FAPESP 2017/25157-0. At Maguari, research was conducted under permit 01506.004836/2014-69 from the Instituto do Patrimônio Histórico e Artístico Nacional (IPHAN) and ICMBio permit 106/14-FNT. At Couro Velho research was conducted under permit 01490.002660/2016-99 from IPHAN. At Versalles research was conducted under permit authorisation MDCyT - UDAM N ${ }^{\circ} 071 /$ 2017. We thank all the residents of the Maguarí, Jamaraquá, Cedro, Couro Velho, and Versalles communities for their hospitality and help.

\section{Appendix A. Supplementary data}

Supplementary data to this article can be found online at https://doi.org/10.1016/j.quascirev.2020.106582.

\section{Author statement}

JI, SE, YM, DA, RG, MR, JGS designed the research; JI, SE, YM, DA, RG, MR, JGS, JW and JH carried out the archaeological, archaeobotanical and palaeoecological work; JI led the writing of the paper with contributions from all other authors.

\section{References}

Aceituno, F.J., Loaiza, N., 2018. The origins and early development of plant food production and farming in Colombian tropical forests. J. Anthropol. Archaeol. 49, 161-172.

Aceituno, F.J., Rojas-Mora, S., 2015. Lithic technology studies in Colombia during the late Pleistocene and early Holocene. Chungara, Revista de Antropología Chilena 47, $13-23$.

Acuña, C., 1891. [1641]. Nuevo descubrimiento del Gran Rio de las Amazonas. J. C. Garcia, Madrid.

Almeida de Oliveira, E., Marimon-Junior, B., Schwantes-Marimon, B., Iriarte, J., Morandi, P., Maezumi, S., Nogueira, D., Aragão, L.E.O., Brasil da Silva, I., Feldpausch, T., 2020. Legacy of Amazonian Dark Earth soils on forest structure and species composition. Global Ecol. Biogeogr. 29, 1458-1473.

Ambrose, S.H., Norr, L., 1993. Experimental evidence for the relationship of the carbon isotope ratios of whole diet and dietary protein to those of bone collagen and carbonate. In: Lambert, J.B., Norr, L. (Eds.), Prehistoric Human Bone: Archaeology at the Molecular Level. Springer Berlin Heidelberg, Berlin, 
Heidelberg, pp. 1-37.

Angulo, E.G., 1998. Interpretación biológica acerca de la domesticación del pato criollo (Cairina moschata), 27. Bulletin de l'Institut Français d'Études Andines, Lima.

Araujo, A.G., Neves, W.A., Piló, L.B., Atui, J.P.V., 2005. Holocene dryness and human occupation in Brazil during the "Archaic Gap". Quat. Res. 64, 298-307.

Arroyo-Kalin, M., 2010. The Amazonian formative: crop domestication and anthropogenic soils. Diversity 2, 473-504.

Arroyo-Kalin, M., 2012. Slash-burn-and-churn: landscape history and crop cultivation in pre-Columbian Amazonia. Quat. Int. 249, 4-18.

Arroyo-Kalin, M., 2014. The variability of Amazonian Dark Earths: comparing anthropogenic soils from three regions of the Amazonian biome. In: Rostain, S. (Ed.), Antes de Orellana. Actas del 3er Encuentro Internacional de Arqueología Amazónica. Instituto Francés de Estudios Andinos, Quito, pp. 323-330.

Arroyo-Kalin, M., 2019. Landscaping, landscape legacies, and landesque capital in pre-Columbian Amazonia. In: Isendahl, C., Stump, D. (Eds.), The Oxford Handbook of Historical Ecology and Applied Archaeology. Oxford University Press, Oxford.

Arroyo-Kalin, M., Riris, P., 2020. Did Amazonian pre-Columbian populations reach carrying capacity during the Late Holocene? SocArXiv May 5. https://doi.org/ 10.31235/osf.io/ws8et.

Balée, W., 1989. The culture of Amazonian forests. Adv. Econ. Bot. 7, 1-21.

Balée, W.L., 1994. Footprints of the Forest: Ka'apor Ethnobotany-The Historical Ecology of Plant Utilization by an Amazonian People. Columbia University Press, New York.

Balée, W., 2013. Cultural Forests of the Amazon. A Historical Ecology of People and Their Landscapes. University of Alabama Press, Tuscaloosa.

Balick, M.J., 1984. Ethnobotany of palms in the neotropics. Adv. Econ. Bot. 1, 9-23. Barker, G., Hunt, C., Barton, H., Gosden, C., Jones, S., Lloyd-Smith, L., Farr, L., Nyirí, B., O'Donnell, S., 2017. The 'cultured rainforests' of Borneo. Quat. Int. 448, 44-61.

Barnosky, A.D., Lindsey, E.L., 2010. Timing of Quaternary megafaunal extinction in South America in relation to human arrival and climate change. Quat. Int. 217, $10-29$.

Barton, H., Denham, T., Neumann, K., Arroyo-Kalin, M., 2012. Long-term perspectives on human occupation of tropical rainforests: an introductory overview. Quat. Int. 249, 1-3.

Bates, J., Singh, R.N., Petrie, C.A., 2017. Exploring Indus crop processing: combining phytolith and macrobotanical analyses to consider the organisation of agriculture in northwest India c. 3200-1500 BC. Veg. Hist. Archaeobotany 26, $25-41$.

Blaauw, M., Christen, J.A., 2013, Bacon Manual V2. 3.3.

Blatrix, R., Roux, B., Béarez, P., Prestes-Carneiro, G., Amaya, M., Aramayo, J.L., Rodrigues, L., Lombardo, U., Iriarte, J., de Souza, J.G., 2018. The unique functioning of a pre-Columbian Amazonian floodplain fishery. Sci. Rep. 8, 1-16.

Borem, A., Lopes, M., Clement, C., Noda, H., 2012. Domestication and Breeding: Amazonian Species. Editora da Universidade Federal Viçosa, Viçosa.

Bozarth, S., Price, K., Woods, W., Neves, E., Rebellato, R., 2009. Phytoliths and terra preta: the Hatahara site example. In: Woods, W.I., Teixeira, W.G., Lehmann, J. Steiner, C., WinklerPrins, A.M.G.A., Rebellato, L. (Eds.), Amazonian Dark Earths: Wim Sombroek's Vision. Springer, New York, pp. 85-98.

Braje, T.J., Dillehay, T.D., Erlandson, J.M., Klein, R.G., Rick, T.C., 2017. Finding the first Americans. Science 358, 592-594.

Bray, W., 2000. Ancient food for thought. Nature 408, 145-146.

Brieger, F.G., Gurgel, J., Patemaniani, E., Blumenschein, A., Alleoni, M., 1958. Races of Maize in Brazil and Other Eastern South American Countries. National Academy of Sciences, Washington, D.C.

Brugger, S.O., Gobet, E., van Leeuwen, J.F., Ledru, M.-P., Colombaroli, D., van der Knaap, W.O., Lombardo, U., Escobar-Torrez, K., Finsinger, W., Rodrigues, L., 2016. Long-term man-environment interactions in the Bolivian Amazon: 8000 years of vegetation dynamics. Quat. Sci. Rev. 132, 114-128.

Bruno, M.C., 2010. Carbonized Plant Remains from Loma Salvatierra, Department of Beni, Bolivia. Zeitschrift für Archäologie Außereuropäischer Kulturen, pp. 151-206.

Bryan, A.L., Casamiquela, R.M., Cruxent, J.M., Gruhn, R., Ochsenius, C., 1978. An El jobo mastodon kill at taima-taima, Venezuela. Science 200, 1275-1277.

Burn, M.J., Mayle, F.E., 2008. Palynological differentiation between genera of the Moraceae family and implications for Amazonian palaeoecology. Rev. Palaeobot. Palynol. 149, 187-201.

Bush, M.B., 2017. Climate science: the resilience of Amazonian forests. Nature 541, $167-168$.

Bush, M.B., McMichael, C.N., 2016. Holocene variability of an Amazonian hyperdominant. J. Ecol. 104, 1370-1378.

Bush, M.B., Weng, C., 2007. Introducing a new (freeware) tool for palynology. J. Biogeogr. 34, 377-380.

Bush, M.B., Dolores, R.P., Colinvaux, P.A., 1989. A 6,000 year history of Amazonian maize cultivation. Nature 340, 303-305.

Bush, M., Silman, M., McMichael, C., Saatchi, S., 2008. Fire, climate change and biodiversity in Amazonia: a Late-Holocene perspective. Phil. Trans. Roy. Soc. Lond. B 363, 1795-1802.

Bush, M.B., Correa-Metrio, A., McMichael, C., Sully, S., Shadik, C., Valencia, B., Guilderson, T., Steinitz-Kannan, M., Overpeck, J., 2016. A 6900-year history of landscape modification by humans in lowland Amazonia. Quat. Sci. Rev. 141, 52-64.

Campbell, L., 1997. American Indian Languages: the Historical Linguistics of Native America. Oxford University Press, Oxford.
Capriles, J.M., Lombardo, U., Maley, B., Zuna, C., Veit, H., Kennett, D.J., 2019. Persistent early to middle holocene tropical foraging in southwestern Amazonia. Science Advances 5, eaav5449.

Carneiro, R., 1960. Slash-and-burn agriculture: a closer look at its implications for settlement patterns. In: Wallace, A. (Ed.), Men and Cultures. University of Pennsylvania, Philadelphia, pp. 229-234.

Caromano, C.F., 2010. Fogo no mundo das águas: Antracologia no sítio Hatahara, Amazônia Central. Unpublished Master thesis. Departamento de Antropologia. Universidade Federal do Rio de Janeiro.

Carson, J.F., Whitney, B.S., Mayle, F.E., Iriarte, J., Prümers, H., Soto, J.D., Watling, J., 2014. Environmental impact of geometric earthwork construction in preColumbian Amazonia. Proc. Natl. Acad. Sci. Unit. States Am. 111, 10497-10502.

Carson, J.F., Mayle, F.E., Whitney, B.S., Iriarte, J., Soto, J.D., 2016. Pre-Columbian ring ditch construction and land use on a 'chocolate forest island' in the Bolivian Amazon. J. Quat. Sci. 31, 337-347.

Castilla-Beltrán, A., Hooghiemstra, H., Hoogland, M.L., Pagán-Jiménez, J., van Geel, B., Field, M.H., Prins, M., Donders, T., Malatesta, E.H., Hung, J.U., 2018. Columbus' footprint in Hispaniola: a paleoenvironmental record of indigenous and colonial impacts on the landscape of the central Cibao Valley, northern Dominican Republic. Anthropocene 22, 66-80.

Cavalcante, P.B., 1991. Frutas Comestíveis da Amazônia, $5^{\text {a }}$ Edição. Museu Paraense Emílio Goeldi, Belém, Brazil.

Chauchat, C., 1975. The paijan complex, pampa de Cupisnique, Peru. Nawpa Pacha 13, 85-96.

Clement, C.R., 1999a. 1492 and the loss of Amazonian crop genetic resources. I. The relation between domestication and human population decline. Econ. Bot. 53, $188-202$.

Clement, C.R., 1999b. 1492 and the loss of Amazonian crop genetic resources. II. Crop biogeography at contact. Econ. Bot. 53, 203-216.

Clement, C.R., McCann, J.M., Smith, N.J., 2004. Agrobiodiversity in Amazonia and its relationship with dark earths. In: Lehmann, J., Kern, D., Woods, W.I. (Eds.), Amazonian Dark Earths: Origins, Properties and Management. Kluwer Academic Publisher, pp. 159-178.

Clement, C.R., de Cristo-Araújo, M., Coppens D’Eeckenbrugge, G., Alves Pereira, A., Picanço-Rodrigues, D., 2010. Origin and domestication of native Amazonian crops. Diversity 2, 72-106.

Clement, C.R., Denevan, W.M., Heckenberger, M.J., Junqueira, A.B., Neves, E.G., Teixeira, W.G., Woods, W.I., 2015. The domestication of Amazonia before European conquest. In: Proceedings of the Royal Society of London B: Biological Sciences, vol. 282, 20150813.

Clement, C.R., Rodrigues, D.P., Alves-Pereira, A., Mühlen, G.S., Cristo-Araújo, M.d. Moreira, P.A., Lins, J., Reis, V.M., 2016. Crop domestication in the upper Madeira River basin. Boletim do Museu Paraense Emílio Goeldi. Ciências Humanas 11, $193-205$.

Colinvaux, P.A., 2008. Amazon Expeditions: My Quest for the Ice-Age Equator. Yale University Press, New Haven.

Colinvaux, P.A., De Oliveira, P.E., Moreno, J.E., Miller, M.C., Bush, M.B., 1996. A long pollen record from lowland Amazonia: forest and cooling in glacial times. Science 274, 85-88.

Corteletti, R., Dickau, R., DeBlasis, P., Iriarte, J., 2015. Revisiting the economy and mobility of southern proto-Jê (Taquara-Itararé) groups in the southern Brazilian highlands: starch grain and phytoliths analyses from the Bonin site, Urubici, Brazil. J. Archaeol. Sci. 58, 46-61.

Cosgrove, R., Field, J., Ferrier, A., 2007. The archaeology of Australia's tropical rainforests. Palaeogeogr Palaeocl 251, 150-173.

Costa, J.A., da Costa, M.L., Kern, D.C., 2013. Analysis of the spatial distribution of geochemical signatures for the identification of prehistoric settlement patterns in ADE and TMA sites in the lower Amazon Basin. J. Archaeol. Sci. 40, $2771-2782$

Cunha, M.C.d., 2019. Antidomestication in the Amazon: swidden and its foes. HAU: Journal of Ethnographic Theory 9, 126-136.

Daggers, L., Plew, M.G., Edwards, A., Evans, S., Trayler, R.B., 2018. Assessing the early holocene environment of northwestern Guyana: an isotopic analysis of human and faunal remains. Lat. Am. Antiq. 29, 279-292.

de Freitas, H.A., Pessenda, L.C.R., Aravena, R., Gouveia, S.E.M., de Souza Ribeiro, A., Boulet, R., 2001. Late Quaternary vegetation dynamics in the southern Amazon Basin inferred from carbon isotopes in soil organic matter. Quat. Res. 55, 39-46.

de Souza, J.G., Schaan, D.P., Robinson, M., Barbosa, A.D., Aragão, L.E., Marimon Jr., B.H., Marimon, B.S., da Silva, I.B., Khan, S.S., Nakahara, F.R., 2018. Pre-Columbian earth-builders settled along the entire southern rim of the Amazon. Nat. Commun. 9, 1-10.

de Souza, J.G., Robinson, M., Maezumi, S.Y., Capriles, J., Hoggarth, J.A., Lombardo, U., Novello, V.F., Apaéstegui, J., Whitney, B., Urrego, D., 2019a. Climate change and cultural resilience in late pre-Columbian Amazonia. Nature ecology \& Evolution 3, 1007-1017.

de Souza, J.G., Alcaina Mateos, J., Madella, M., 2020. Archaeological expansions in tropical South America during the late Holocene: assessing the role of demic diffusion. PloS One 15, e0232367.

de Souza, N.B., Junqueira, A.B., Struik, P.C., Stomph, T., Clement, C.R., 2019b. The role of fertile anthropogenic soils in the conservation of native and exotic agrobiodiversity in Amazonian homegardens. Agrofor. Syst. 93, 471-482.

de Vaca, A.N.C., 1542. 1906. Relación de los naufragios y Comentarios de Alvar Núñez Cabeza de Vaca. Idamor Moreno, Madrid.

Deininger, M., Ward, B.M., Novello, V.F., Cruz, F.W., 2019. Late Quaternary variations in the South American monsoon system as inferred by speleothems-new 
perspectives using the SISAL database. Quaternary 2, 6

Denevan, W.M., 1996. A bluff model of riverine settlement in prehistoric Amazonia. Ann. Assoc. Am. Geogr. 86, 654-681.

Denevan, W.M., 2001. Cultivated Landscapes of Native Amazonia and the Andes. Oxford University Press, New York.

Denevan, W.M., 2004. Semi-intensive pre-European cultivation and the origins of anthropogenic Dark Earths in Amazonia. In: Glaser, B., Woods, W.I. (Eds.), Amazonian Dark Earths: Explorations in Space and Time. Springer, Berlin, pp. 135-141.

Denham, T., 2018. Origin and Development of Agriculture in New Guinea, Island Melanesia and Polynesia. Oxford Research Encyclopedia of Environmental Science.

Denham, T.P., Vrydaghs, L., 2007. Rethinking agriculture: introductory thoughts. In: Denham, T.P., Iriarte, J., Vrydaghs, L. (Eds.), Rethinking Agriculture: Archaeological and Ethnoarchaeological Perspectives. Routledge, London, pp. 1-16.

Denham, T.P., Haberle, S.G., Lentfer, C., Fullagar, R., Field, J., Therin, M., Porch, N., Winsborough, B., 2003. Origins of agriculture at kuk swamp in the highlands of new Guinea. Science 301, 189-193.

Denham, T.P., Iriarte, J., Vrydaghs, L., 2007. Rethinking Agriculture: Archaeological and Ethnoarchaeological Perspectives. Routledge, London.

Dickau, R., Ranere, A.J., Cooke, R.G., 2007. Starch grain evidence for the preceramic dispersals of maize and root crops into tropical dry and humid forests of Panama. Proc. Natl. Acad. Sci. Unit. States Am. 104, 3651.

Dickau, R., Bruno, M.C., Iriarte, J., Prümers, H., Jaimes Betancourt, C., Holst, I., Mayle, F.E., 2012. Diversity of cultivars and other plant resources used at habitation sites in the Llanos de Mojos, Beni, Bolivia: evidence from macrobotanical remains, starch grains, and phytoliths. J. Archaeol. Sci. 39, 357-370.

Dickau, R., Whitney, B.S., Iriarte, J., Mayle, F.E., Soto, J.D., Metcalfe, P., StreetPerrott, F.A., Loader, N.J., Ficken, K.J., Killeen, T.J., 2013. Differentiation of neotropical ecosystems by modern soil phytolith assemblages and its implications for palaeoenvironmental and archaeological reconstructions. Rev. Palaeobot. Palynol. 193, 15-37.

Dickau, R., Aceituno, F.J., Loaiza, N., López, C., Cano, M., Herrera, L., Restrepo, C., Ranere, A.J., 2015. Radiocarbon chronology of terminal pleistocene to middle holocene human occupation in the middle Cauca Valley, Colombia. Quat. Int. 363, 43-54.

Dillehay, T.D., 2011. From Foraging to Farming in the Andes: New Perspectives on Food Production and Social Organization. Cambridge University Press.

Dillehay, T.D., 2017. Where the Land Meets the Sea: Fourteen Millennia of Human History at Huaca Prieta, Peru. University of Texas Press, Austin.

Dillehay, T., Rossen, J., 2002. Plant food and its implications for the peopling of the New World. In: Jablonski, J. (Ed.), The First Americans: the Pleistocene Colonization of the New World. Wattis Symposium Series in Anthropology. Memoirs of the California Academy of Sciences, San Francisco, pp. 237-253.

Dillehay, T.D., Rossen, J., Andres, T.C., Williams, D.E., 2007. Preceramic adoption of peanut, squash, and cotton in northern Peru. Science 316, 1890-1893.

Dillehay, T.D., Rossen, J., Ugent, D., Karathanasis, A., Vásquez, V., Netherly, P.J., 2010. Early Holocene coca chewing in northern Peru. Antiquity 84, 939-953.

Doughty, C.E., Faurby, S., Svenning, J.C., 2016a. The impact of the megafauna extinctions on savanna woody cover in South America. Ecography 39, 213-222.

Doughty, C.E., Wolf, A., Morueta-Holme, N., Jørgensen, P.M., Sandel, B., Violle, C., Boyle, B., Kraft, N.J., Peet, R.K., Enquist, B.J., 2016b. Megafauna extinction, tree species range reduction, and carbon storage in Amazonian forests. Ecography 39, 194-203.

Dounias, E., 2001. The management of wild yam tubers by the Baka Pygmies in Southern Cameroon. Afr. study Monogr. Suppl. 26, 135-156.

Eder, F.J., 1985 [1772]. Breve Descripción de las Reducciones de Mojos. Historia Boliviana, Cochabamba.

Emperaire, L., 2001. Elementos de discussão sobre a conservação da agrobiodiversidade: o exemplo da mandioca (Manihot esculenta Crantz) na Amazônia brasileira. Capobianco J.-P., coord.: Biodiversidade da Amazônia, Estação Liberdade. ISA/São Paulo, pp. 225-234.

Epps, P., Salanova, A.P., 2013. The languages of Amazonia. Tipití 11, 1-28.

Erickson, C.L., 2000. An artificial landscape-scale fishery in the Bolivian Amazon. Nature 408, 190-193.

Erickson, C., 2004. Historical ecology and future explorations. In: Lehmann, J., Kern, D.C., Glaser, B., Woods, W.I. (Eds.), Amazonian Dark Earths: Origins, Properties, Management. Springer, New York, pp. 455-500.

Erickson, C.L., 2008. Amazonia: the historical ecology of a domesticated landscape. In: Silverman, H., Isbell, W. (Eds.), The Handbook of South American Archaeology. Springer, New York, pp. 157-183.

Eriksen, L., 2011. Nature and Culture in Prehistoric Amazonia: Using GIS to Reconstruct Ancient Ethnogenetic Processes from Archaeology, Linguistics, Geography, and Ethnohistory, Studies in Human Ecology. Lund University, Lund.

Ezell, K.C., Pearsall, D.M., Zeidler, J.A., 2006. Root and tuber phytoliths and starch grains document manioc (Manihot esculenta) arrowroot (Maranta arundinacea) and llerén (Calathea sp.) at the real alto site Ecuador. Econ. Bot. 60, 103-120.

Fausto, C., 2001. Inimigos Fies: História, Guerra e Xamanismo na Amazônia. EDUSP, São Paulo.

Fausto, C., Neves, E.G., 2018. Was there ever a neolithic in the neotropics? Plant familiarisation and biodiversity in the Amazon. Antiquity 92, 1604-1618.

Favero, A.P., Valls, J.F.M., 2009. Domesticação e melhoramento de amendoim. In: Borem, A., Lopes, M.T.G., Clement, C.R. (Eds.), Domesticação e melhoramento: espécies amazônicas. Viçosa: Editora da Universidade Federal de Viçosa. Editora da Universidade Federal de Viçosa, Viçosa, pp. 237-249.
Fernandes Caromano, C., Matthews Cascon, L., Góes Neves, E., Scheel-Ybert, R., 2013. Revealing fires and rich diets: macro-and micro-archaeobotanical analysis at the Hatahara Site. Central Amazonia. Tipití 11, 40-51.

Flantua, S.G., Hooghiemstra, H., Grimm, E.C., Behling, H., Bush, M.B., GonzálezArango, C., Gosling, W.D., Ledru, M.-P., Lozano-García, S., Maldonado, A., 2015a. Updated site compilation of the Latin American pollen database. Rev. Palaeobot. Palynol. 223, 104-115.

Flantua, S., Hooghiemstra, H., Vuillle, M., Behling, H., Carson, J., Gosling, W., Hoyos, I., Ledru, M., Montoya, E., Mayle, F., 2015b. Climate variability and human impact on the environment in South America during the last 2000 years: synthesis and perspectives. Clim. Past Discuss 11, 3475-3565.

Franco-Moraes, J., Baniwa, A.F., Costa, F.R., Lima, H.P., Clement, C.R., Shepard Jr., G.H., 2019. Historical landscape domestication in ancestral forests with nutrientpoor soils in northwestern Amazonia. For. Ecol. Manag. 446, 317-330.

Fraser, J.A., 2010. Caboclo horticulture and Amazonian dark earths along the middle Madeira River, Brazil. Hum. Ecol. 38, 651-662.

Fraser, J.A., Clement, C.R., 2008. Dark earths and manioc cultivation in central Amazonia: a window on pre-columbian agricultural systems? Boletim do museu paraense emílio goeldi. Ciências Humanas 3, 175-194.

Fraser, J., Cardoso, T., Junqueira, A., Falcão, N.P.S., Clement, C.R., 2009. Historical ecology and dark earths in whitewater and blackwater landscapes: comparing the Middle Madeira and Lower Negro rivers. In: Woods, W.I., Teixeira, W.G., Lehmann, J., Steiner, C., WinklerPrins, A.M.G.A., Rebellato, L. (Eds.), Amazonian Dark Earths: Wim Sombroek's Vision. Springer, Berling, pp. 229-264.

Fraser, J.A., Alves-Pereira, A., Junqueira, A.B., Peroni, N., Clement, C.R., 2012. Convergent adaptations: bitter manioc cultivation systems in fertile anthropogenic dark earths and floodplain soils in Central Amazonia. PloS One 7, e43636.

Frikel, P., 1978. Áreas de arboricultura pré-agrícola na Amazônia. Notas preliminares. Revista de Antropologia, pp. 45-52.

German, L., 2003. Ethnoscientific understandings of Amazonian dark earths. In: Lehmann, J., Kern, D.C., Glaser, B., Woods, W.I. (Eds.), Amazonian Dark Earths. Kluwer Academics, Dordrecht, pp. 179-201.

Gerstel, D.U., Sisson, V.A., 1995. Tobacco, nicotiana tabacum (solanaceae). In: Smart, J., Simmonds, J., Norman, W. (Eds.), Evolution of Crop Plants. Longman, London.

Glaser, B., Birk, J.J., 2012. State of the scientific knowledge on properties and genesis of Anthropogenic Dark Earths in Central Amazonia 'terra preta de Índio'. Geochem. Cosmochim. Acta 82, 39-51.

Glaser, B., Woods, W., 2004. Amazonian Dark Earths. Springer, Berlin.

Glaser, B., Haumaier, L., Guggenberger, G., Zech, W., 2001. The'Terra Preta'phenomenon: a model for sustainable agriculture in the humid tropics. Naturwissenschaften $88,37-41$.

Gnecco, C., 2003. Against ecological reductionism: late Pleistocene hunter-gatherers in the tropical forests of northern South America. Quat. Int. 109-110, 13-21.

Gomes, D.M.C., 2008. Cotidiano e poder na Amazônia pré-colonial. EDUSP/FAPESP.

Gonda, R., 2018. Pre-Columbian Land Use and its Modern Legacy in the PurusMadeira Interfluve, Central Amazonia. Department of Archaeology. University of Exeter, Exeter.

Guimarães Jr., P.R., Galetti, M., Jordano, P., 2008. Seed dispersal anachronisms: rethinking the fruits extinct megafauna ate. PloS One 3, e1745.

Guix, J., 2005. Evidence of old anthropic effects in forests at the confluence of the Caurés and Negro Rivers, NW Amazonia: the role of indians and caboclos. Grupo de Estudos Ecológicos 8, 1-27.

Håkansson, N.T., Widgren, M., 2016. Landesque Capital: the Historical Ecology of Enduring Landscape Modifications. Routledge, London.

Hanelt, P., Buttner, R., Mansfeld, R., 2001. Mansfeld's Encyclopedia of Agricultural and Horticultural Crops (Except Ornamentals). Springer, Berlin.

Harlan, J.R., 1995. The Living Fields: Our Agricultural Heritage. Cambridge University Press, Cambridge.

Harris, D.R., 1977. Alternative pathways toward agriculture. In: Reed, C. (Ed.), Origins of Agriculture. Mouton, The Hague, pp. 179-243.

Harris, D.R., Hillman, G., 1989. An evolutionary continuum of people-plant interaction. In: Harris, D.R., Hillman, G. (Eds.), Foraging and farming: the evolution of plant exploitation, pp. 11-26. Routeledge, London.

Hecht, S.B., 2003. Indigenous soil management and the creation of terra mulata and terra preta in the Amazon Basin. In: Lehmann, J., Kern, D., Glaser, B., Woods, W.I. (Eds.), Amazonian Dark Earths: Origin Properties and Management. Springer, Dordrecht, pp. 355-372.

Hecht, S.B., 2009. Kayapó savanna management: fire, soils, and forest islands in a threatened biome. In: Woods, W.I., Teixeira, W.G., Lehmann, J., Steiner, C., Winkler, P.A., Rebellato, L. (Eds.), Amazonian Dark Earths: Wim Sombroek's Vision. Springer, Dordrecht, pp. 143-162.

Heckenberger, M., 2002. Rethinking the Arawakan diaspora: hierarchy, regionality, and the Amazonian formative. In: Hill, J.D., Santos-Granero, F. (Eds.), Comparative Arawakan Histories: Rethinking Language Family and Culture Area in Amazonia. University of Illinois Press, Urbana, pp. 99-122.

Heckenberger, M., 2005. The Ecology of Power: Culture, Place, and Personhood in the Southern Amazon, AD 1000-2000. Routledge, New York/London.

Heckenberger, M., Neves, E.G., 2009. Amazonian archaeology. Annu. Rev. Anthropol. $38,251-266$.

Heckenberger, M.J., Petersen, J.B., Neves, E.G., 1999. Village size and permanence in Amazonia: two archaeological examples from Brazil. Lat. Am. Antiq. 353-376.

Heckenberger, M.J., Russell, J.C., Fausto, C., Toney, J.R., Schmidt, M.J., Pereira, E., Franchetto, B., Kuikuro, A., 2008. Pre-Columbian urbanism, anthropogenic 
landscapes, and the future of the Amazon. Science 321, 1214-1217.

Heriarte, M.d., 1874. Descripção do Estado do Maranhão, Pará, Corupá e Rio das Amazonas. Impresa do Filho de Carlos Gerold, Vienna, p. 1662.

Hermenegildo, T., O'Connell, T.C., Guapindaia, V.L., Neves, E.G., 2017. New evidence for subsistence strategies of late pre-colonial societies of the mouth of the Amazon based on carbon and nitrogen isotopic data. Quat. Int. 448, 139-149.

Herrera, L.F., Cavelier, I., Rodriguez, C., Mora, S., 1992. The technical transformation of an agricultural system in the Colombian Amazon. World Archaeol. 24, 98-113.

Hilbert, L., Neves, E.G., Pugliese, F., Whitney, B.S., Shock, M., Veasey, E., Zimpel, C.A., Iriarte, J., 2017. Evidence for mid-Holocene rice domestication in the Americas. Nature ecology \& evolution 1, 1693-1698.

Hiraoka, M., Yamamoto, S., Matsumoto, E., Nakamura, S., Falesi, I., Ronaldo, A., Baena, C., 2004. Contemporary use and management of amazonian dark earths. In: Lehmann, J., Kern, D., Glaser, B., Woods, W.I. (Eds.), Amazonian Dark Earths: Origins, Properties, Management. Springer, Dordrecht, pp. 387-406.

Hornborg, A., Eriksen, L., Bogadóttir, R., 2014. Correlating landesque capital and ethno-political integration in pre-Columbian South America. In: Håkansson, T., Widgren, M. (Eds.), Landesque Capital: the Historical Ecology of Enduring Landscape Modifications. Left Coast Press, Walnut Creek, pp. 215-231.

Huisman, S.N., Raczka, M., McMichael, C.N., 2018. Palm phytoliths of mid-elevation Andean forests. Frontiers in Ecology and Evolution 6, 193.

Iriarte, J., 2007. New perspectives on plant domestication and the development of agriculture in the New World. In: Denham, T.P., Iriarte, J., Vyrdaghs, L. (Eds.), Rethinking Agriculture: Archaeological and Ethnoarchaeological Perspectives. Left Coast Press, Wallnut Creek, pp. 165-186.

Iriarte, J., 2009. Narrowing the gap exploring the diversity of early food-production economies in the Americas. Curr. Anthropol. 50, 677-680.

Iriarte, J., Dickau, R., 2012. As culturas do milho? Arqueobotânica de las sociedades hidráulicas das terras baixas sul-americanas. Amazônica 4, 30-58.

Iriarte, J., Holst, I., Marozzi, O., Listopad, C., Alonso, E., Rinderknecht, A., Montana, J., 2004. Evidence for cultivar adoption and emerging complexity during the midHolocene in the La Plata basin. Nature 432, 614-617.

Iriarte, J., Glaser, B., Watling, J., Wainwright, A., Birk, J.J., Renard, D., Rostain, S., McKey, D., 2010. Late Holocene Neotropical agricultural landscapes: phytolith and stable carbon isotope analysis of raised fields from French Guianan coastal savannahs. J. Archaeol. Sci. 37, 2984-2994.

Iriarte, J., Power, M.J., Rostain, S., Mayle, F.E., Jones, H., Watling, J., Whitney, B.S., McKey, D.B., 2012. Fire-free land use in pre-1492 Amazonian savannas. Proc. Natl. Acad. Sci. Unit. States Am. 109, 6473-6478.

Iriarte, J., Smith, R.J., de Souza, J.G., Mayle, F.E., Whitney, B.S., Cárdenas, M.L., Singarayer, J., Carson, J.F., Roy, S., Valdes, P., 2017. Out of Amazonia: lateholocene climate change and the tupi-guarani trans-continental expansion. Holocene 27, 967-975.

Iriarte, J., Robinson, M., de Souza, J., Damasceno, A., da Silva, F., Nakahara, F., Ranzi, A., Aragão, L., 2020. Geometry by design: contribution of lidar to the understanding of settlement patterns of the mound villages in SW Amazonia. Journal of Computer Applications in Archaeology 3, 151-170.

Jones, M., 2009. Moving north: archaeobotanical evidence for plant diet in Middle and Upper Paleolithic Europe. In: Hublin, J., Richards, M. (Eds.), The Evolution of Hominin Diets. Springer, Dordrecht, pp. 171-180.

Junqueira, A.B., Shepard, G.H., Clement, C.R., 2010. Secondary forests on anthropogenic soils in Brazilian Amazonia conserve agrobiodiversity. Biodivers. Conserv. 19, 1933-1961.

Junqueira, A.B., Shepard Jr., G.H., Clement, C.R., 2011. Secondary forests on anthropogenic soils of the Middle Madeira River: valuation, local knowledge, and landscape domestication in Brazilian Amazonia. Econ. Bot. 65, 85-99.

Junqueira, A.B., Levis, C., Bongers, F., Peña-Claros, M., Clement, C.R., Costa, F., Ter Steege, H., 2017. Response to Comment on "Persistent effects of pre-Columbian plant domestication on Amazonian forest composition". Science 358.

Kelly, T.J., Lawson, I.T., Roucoux, K.H., Baker, T.R., Honorio-Coronado, E.N., Jones, T.D., Rivas Panduro, S., 2018. Continuous human presence without extensive reductions in forest cover over the past 2500 years in an aseasonal Amazonian rainforest. J. Quat. Sci. 33, 369-379.

Kennett, D.J., Prufer, K.M., Culleton, B.J., George, R.J., Robinson, M., Trask, W.R. Buckley, G.M., Moes, E., Kate, E.J., Harper, T.K., 2020. Early isotopic evidence for maize as a staple grain in the Americas. Science Advances 6, eaba3245.

Kern, D.C., Kampf, N., 1989. Antigos assentamentos indígenas na formação de solos com terra preta arqueológica na região de Oriximiná, Pará. Rev. Bras. Ciência do Solo $13,219-225$

Kern, D.C., D'aquino, G., Rodrigues, T.E., Frazao, F.J.L., Sombroek, W., Myers, T.P., Neves, E.G., 2003. Distribution of amazonian dark earths in the Brazilian Amazon. In: Lehmann, J., Kern, D., Glaser, B., Woods, W.I. (Eds.), Amazonian Dark Earths. Springer, Dordrecht, pp. 51-75.

Kern, D.C., Lima, H.P., da Costa, J.A., de Lima, H.V., Browne Ribeiro, A., Moraes, B.M., Kämpf, N., 2017. Terras pretas: approaches to formation processes in a new paradigm. Geoarchaeology 32, 694-706.

Kipnis, R., 1998. Early hunter-gatherers in the Americas: perspectives from central Brazil. Antiquity 72, 581-592.

Kistler, L., Newsom, L.A., Ryan, T.M., Clarke, A.C., Smith, B.D., Perry, G.H., 2015. Gourds and squashes (Cucurbita spp.) adapted to megafaunal extinction and ecological anachronism through domestication. Proc. Natl. Acad. Sci. Unit. States Am. 112, 15107-15112.

Kistler, L., Maezumi, S.Y., De Souza, J.G., Przelomska, N.A., Costa, F.M., Smith, O., Loiselle, H., Ramos-Madrigal, J., Wales, N., Ribeiro, E.R., 2018. Multiproxy evidence highlights a complex evolutionary legacy of maize in South America. Science 362, 1309-1313.

Larson, G., Piperno, D.R., Allaby, R.G., Purugganan, M.D., Andersson, L., ArroyoKalin, M., Barton, L., Vigueira, C.C., Denham, T., Dobney, K., 2014. Current perspectives and the future of domestication studies. Proc. Natl. Acad. Sci. Unit. States Am. 111, 6139-6146.

Ledru, M.-P., 1993. Late Quaternary environmental and climatic changes in central Brazil. Quat. Res. 39, 90-98.

Lehmann, J., da Silva Jr., J.P., Steiner, C., Nehls, T., Zech, W., Glaser, B., 2003. Nutrient availability and leaching in an archaeological Anthrosol and a Ferralsol of the Central Amazon basin: fertilizer, manure and charcoal amendments. Plant Soil 249, 343-357.

Lehmann, J., Kern, D.C., Glaser, B., Woods, W.I., 2004. Amazonian Dark Earths: Origin, Properties, Management. Springer Dortdrech.

Lévi-Strauss, C., 1952. The use of wild plants in tropical South America. Econ. Bot. 6 , $252-270$

Levis, C., de Souza, P.F., Schietti, J., Emilio, T., da Veiga Pinto, J.L.P., Clement, C.R., Costa, F.R.C., 2012. Historical human footprint on modern tree species composition in the Purus-Madeira interfluve, central Amazonia. PloS One 7, e48559.

Levis, C. Silva, M. Silva, M., Moraes, C.P., Neves, E., Tamanaha, E., Flores, B. Clement, C.R., 2014. What do we know about the distribution of Amazonian Dark Earth along tributary rivers in Central Amazonia? In: Rostain, S. (Ed.) Antes de Orellana-Actas del 3er Encuentro Internacional de Arqueología Amazónica. Instituto Frances de Estudios Andinos, Quito, pp. 305-312.

Levis, C., Costa, F.R., Bongers, F., Peña-Claros, M., Clement, C.R., Junqueira, A.B. Neves, E.G., Tamanaha, E.K., Figueiredo, F.O., Salomão, R.P., 2017. Persistent effects of pre-Columbian plant domestication on Amazonian forest composition. Science 355, 925-931.

Lins, J., Lima, H.P., Baccaro, F.B., Kinupp, V.F., Shepard Jr., G.H., Clement, C.R., 2015. Pre-Columbian floristic legacies in modern homegardens of Central Amazonia. PloS One 10, e0127067.

Lombardo, U., Szabo, K., Capriles, J.M., May, J.-H., Amelung, W., Hutterer, R. Lehndorff, E., Plotzki, A., Veit, H., 2013. Early and middle holocene huntergatherer occupations in Western Amazonia: the hidden shell middens. PloS One 8, e72746.

Lombardo, U., Iriarte, J., Hilbert, L., Ruiz-Pérez, J., Capriles, J.M., Veit, H., 2020. Early Holocene crop cultivation and landscape modification in Amazonia. Nature 581, 190-193.

López-Zent, E., Zent, S., 2004. Amazonian Indians as ecological disturbance agents the Hotï of the sierra de Maigualida, Venezuelan Guayana. Adv. Econ. Bot. 15 79-112.

Lothrop, S.K., 1961. Early migrations to Central and South America: an anthropological problem in the light of other sciences. J. Roy. Anthropol. Inst. G. B. Ireland 91, 97-123.

Lynch, T.F., 1990. Glacial-age man in South America? A critical review. Am. Antiq. $12-36$.

Macedo, R., 2014. Pedogênese e indicadores pedoarqueológicos em Terra Preta de Índio no município de Iranduba-AM, Escola Superior de Agricultura Luiz de Queiroz. Universidade de São Paulo, São Paulo.

Maezumi, S., Amstrong, A., Elliott, S., Robinson, M., de Souza, J.G., Alves, D., Hilbert L., Gosling, W., Iriarte, J. in preparation. Climate, Fire, and Human Interactions in the Amazon Rainforest Ecotone. Philosophical Transactions of the Royal Society B.

Maezumi, S.Y., Alves, D., Robinson, M., de Souza, J.G., Levis, C., Barnett, R.L., de Oliveira, E.A., Urrego, D., Schaan, D., Iriarte, J., 2018. The legacy of 4,500 years of polyculture agroforestry in the eastern Amazon. Nature plants 4, 540-547.

Magalhães, M.P., Lima, P.G.C., Santos, R.d.S., Maia, R.R., Schmidt, M., Barbosa, C.A.P. Fonseca, J.A.d., 2019. O Holoceno inferior e a antropogênese amazônica na longa história indígena da Amazônia oriental (Carajás, Pará, Brasil). Boletim do Museu Paraense Emílio Goeldi. Ciências Humanas 14, 291-326.

Maggard, G.J., 2015. The El Palto phase of northern Perú: cultural diversity in the late Pleistocene-early Holocene. Chungara, Revista de Antropología Chilena 47, 25-40.

Major, J., DiTommaso, A., Lehmann, J., Falcao, N.P., 2005. Weed dynamics on amazonian dark earth and adjacent soils of Brazil. Agric. Ecosyst. Environ. 111, $1-12$.

Martinelli, L.A., Ometto, J.P.H.B., Ishida, F.Y., Domingues, T.F., Nardoto, G.B., Oliveira, R.S., Ehleringer, J.R., 2007. The use of carbon and nitrogen stable isotopes to track effects of land-use changes in the Brazilian Amazon region. Terrestrial Ecology 1, 301-318.

Matsuoka, Y., Vigouroux, Y., Goodman, M.M., Sanchez, G., 2002. A single domestication for maize shown by multilocus microsatellite genotyping. Proc. Natl. Acad. Sci. U.S.A. 99, 6080.

Mattos, J.R., 1972. O Pinheiro Brasileiro. Artes Graficas Princesa Ltda, Lages.

Mayle, F.E., Iriarte, J., 2014. Integrated palaeoecology and archaeology - a powerful approach for understanding pre-Columbian Amazonia. J. Archaeol. Sci. 51, 54-64.

Mayle, F.E., Burbridge, R., Killeen, T.J., 2000. Millennial-scale dynamics of southern Amazonian rain forests. Science 290, 2291-2294.

McKey, D., Beckerman, S., 1993. Chemical ecology, plant evolution and traditional manioc cultivation systems. Man Biosph. Ser. 13, 83-83.

McKey, D., Cavagnaro, T.R., Cliff, J., Gleadow, R., 2010a. Chemical ecology in coupled human and natural systems: people, manioc, multitrophic interactions and global change. Chemoecology 20, 109-133.

McKey, D., Rostain, S., Iriarte, J., Glaser, B., Birk, J.J., Holst, I., Renard, D., 2010b. Pre- 
Columbian agricultural landscapes, ecosystem engineers, and self-organized patchiness in Amazonia. Proc. Natl. Acad. Sci. Unit. States Am. 107, 7823-7828.

McKey, D.B., Durécu, M., Pouilly, M., Béarez, P., Ovando, A., Kalebe, M., Huchzermeyer, C.F., 2016. Present-day African analogue of a pre-European Amazonian floodplain fishery shows convergence in cultural niche construction. Proc. Natl. Acad. Sci. Unit. States Am. 113, 14938-14943.

McMichael, C., Piperno, D., Bush, M., Silman, M., Zimmerman, A., Raczka, M., Lobato, L., 2012. Sparse pre-Columbian human habitation in western Amazonia. Science 336, 1429-1431.

McMichael, C., Palace, M., Bush, M., Braswell, B., Hagen, S., Neves, E., Silman, M., Tamanaha, E., Czarnecki, C., 2014. Predicting pre-Columbian anthropogenic soils in Amazonia. Proc. Biol. Sci. 281, 20132475.

McMichael, C.H., Feeley, K.J., Dick, C.W., Piperno, D.R., Bush, M.B., 2017. Comment on "Persistent effects of pre-Columbian plant domestication on Amazonian forest composition". Science 358.

McNeil, C.L., Burney, D.A., Burney, L.P., 2010. Evidence disputing deforestation as the cause for the collapse of the ancient Maya polity of Copan, Honduras. Proc. Natl. Acad. Sci. Unit. States Am. 107, 1017-1022.

Medina, J.T., 1934. The Discovery of the Amazon. American Geographical Society, New York.

Meggers, B.J., 2001. The mystery of the Marajoara: an ecological solution. Amazoniana: Limnologia et Oecologia Regionalis Systematis Fluminis Amazonas 16, $421-440$.

Mercader, J., 2002. Under the Canopy: the Archaeology of Tropical Rain Forests. Rutgers University Press, New Brunswick.

Miller, E.T., 1992. Arqueologia nos empreendimentos hidrelétricos da Eletronorte: resultados preliminares. Eletronorte. Ministerio de Minas e Energia, Brasilia.

Montoya, E., Lombardo, U., Levis, C., Aymard, G.A., Mayle, F.E., 2020. Human contribution to Amazonian plant diversity: legacy of pre-Columbian land use in modern plant communities. In: Rull, V., Carnaval, A. (Eds.), Neotropical Diversification: Patterns and Processes. Springer, Cham, pp. 495-520.

Mora, S., 2003. Early Inhabitants of the Amazonian Tropical Rain Forest: a Study of Humans and Environmental Dynamics. University of Pittsburgh Latin American Archaeology Reports, Pittsburgh.

Mora, S., Herrera, L.F., Cavalier, I., Rodríguez, C., 1991. Cultivars, Anthropic Soils, and Stability: a Preliminary Report of Archaeological Research in Araracuara, Colombian Amazonia. University of Pittsburgh Latin American Archaeology Reports, Pittsburgh.

Moraes, C.d.P., 2015. O determinismo agrícola na arqueologia amazônica. Estud. Avançados 29, 25-43.

Moran, E.F., 1993. Through Amazonian Eyes: the Human Ecology of Amazonian Populations. University of Iowa Press, Iowa City.

Morcote-Ríos, G., Bernal, R., 2001. Remains of palms (Palmae) at archaeological sites in the New World: a review. Bot. Rev. 67, 309-350.

Morcote-Ríos, G., Beltrán, J., Peña, P., 2010. Determinación de semillas y restos vegetales arqueológicos. Proyecto Arqueológico Aerocafé, Bogotá, Colombia (Unpublished Report).

Morcote-Ríos, G., Aceituno, F.J., León Sicard, T.I.R., S, Antes de, Orellana, p., 2014. Recolectores del Holoceno Temprano en la Floresta Amazónica Colombiana. In: Rostain, S. (Ed.), Actas del 3er Encuentro Internacional de Arqueología Amazónica. Instituto Frances de Estudios Andinos, Quito, pp. 39-50.

Morcote-Ríos, G., Giraldo-Cañas, D., Raz, L., 2015. Catálogo ilustrado de fitolitos contemporáneos con énfasis arqueológico y paleoecológico I. Gramíneas amazónicas de Colombia. Universidad Nacional de Colombia, Bogotá, Colombia.

Morcote-Ríos, G., Bernal, R., Raz, L., 2016. Phytoliths as a tool for archaeobotanical, palaeobotanical and palaeoecological studies in Amazonian palms. Bot. J. Linn. Soc. $182,348-360$.

Morcote-Ríos, G., Aceituno, F.J., Iriarte, J., Robinson, M., Chaparro-Cárdenas, J.L., 2020. Colonisation and early peopling of the Colombian Amazon during the late pleistocene and the early holocene: new evidence from La serranía La Lindosa. Quaternaty International. https://doi.org/10.1016/j.quaint.2020.04.026.

Moreira, P.A., Lins, J., Dequigiovanni, G., Veasey, E.A., Clement, C.R., 2015. The domestication of annatto (Bixa orellana) from Bixa urucurana in Amazonia. Econ. Bot. 69, 127-135.

Muñoz-Rodríguez, P., Carruthers, T., Wood, J.R., Williams, B.R., Weitemier, K., Kronmiller, B., Ellis, D., Anglin, N.L., Longway, L., Harris, S.A., 2018. Reconciling conflicting phylogenies in the origin of sweet potato and dispersal to Polynesia. Curr. Biol. 28, 1246-1256 e1212.

Myers, T.P., 1974. Spanish contacts and social change on the Ucayali River, Peru. Ethnohistory 135-157.

Myers, T.P., 2004. Dark earth in the upper Amazon. In: Glaser, B., Woods, W.I. (Eds.), Amazonian Dark Earths: Explorations in Space and Time. Springer, Berlin, pp. 67-94.

Neff, H., Pearsall, D.M., Jones, J.G., Arroyo de Pieters, B., Freidel, D.E., 2006. Climate change and population history in the Pacific lowlands of southern Mesoamerica. Quat. Res. 65, 390-400.

Neves, E.G., 2007. El Formativo que nunca terminó: la larga historia de estabilidad en las ocupaciones humanas de la Amazonía central. Boletín de Arqueología PUCP, pp. 117-142.

Neves, E.G., 2013. Was agriculture a key productive activity in pre-colonial Amazonia? The stable productive basis for social equality in the Central Amazon. In: Brondizio, E.S., Moran, E.F. (Eds.), Human-Environment Interactions. Springer, Dordrecht, pp. 371-388.

Neves, E.G., Heckenberger, M.J., 2019. The call of the wild: rethinking food production in ancient Amazonia. Annu. Rev. Anthropol. 48, 371-388.
Neves, E., Pugliese Jr., F., Shock, M., Furquim Pereira, L., Zimpel Neto, C., Gibertoni Carneiro, C.I., 2016. Pesquisa e Formação nos Sítios Arqueológicos Espinhara e Sol de Campinas do Acre - PESC - Relatorio Final. IPHAN, University of Sao Paulo.

Nevle, R.J., Bird, D.K., 2008. Effects of syn-pandemic fire reduction and reforestation in the tropical Americas on atmospheric CO2 during European conquest. Palaeogeogr Palaeocl 264, 25-38.

Nichols, J., 1992. Linguistic Diversity in Space and Time. University of Chicago Press, Chicago.

Noelli, F.S., 2008. The Tupi expansion. In: Silverman, H., Isbell, W.H. (Eds.), Handbook of South American Archaeology. Springer, New York, pp. 659-670.

Odonne, G., Van den Bel, M., Burst, M., Brunaux, O., Bruno, M., Dambrine, E., Davy, D., Desprez, M., Engel, J., Ferry, B., 2019. Long-term influence of early human occupations on current forests of the Guiana Shield. Ecology 100, e02806.

Oliveira-Filho, A.d., Ratter, J., 1995. A study of the origin of central Brazilian forests by the analysis of plant species distribution patterns. Edinb. J. Bot. 52, 141-194.

Oliver, J.R., 2008. The archaeology of agriculture in ancient Amazonia. In: Silverman, H., Isbell, W.H. (Eds.), Handbook of South American Archaeology. Springer, New York, pp. 185-216.

Olsen, K.M., Schaal, B.A., 1999. Evidence on the origin of cassava: phylogeography of Manihot esculenta. Proc. Natl. Acad. Sci. Unit. States Am. 96, 5586.

Olsen, K.M., Schaal, B.A., 2001. Microsatellite variation in cassava (Manihot esculenta, Euphorbiaceae) and its wild relatives: further evidence for a southern Amazonian origin of domestication. Am. J. Bot. 88, 131-142.

Oyuela-Caycedo, A., Bonzani, R., 2005. San Jacinto 1. A Historical Ecological Approach to an Archaic Site in Colombia. University of Alabama Press, Tuscaloosa.

Pagán-Jiménez, J.R., Rodríguez-Ramos, R., Reid, B.A., van den Bel, M., Hofman, C.L., 2015. Early dispersals of maize and other food plants into the Southern Caribbean and Northeastern South America. Quat. Sci. Rev. 123, 231-246.

Paz-Rivera, C., Putz, F.E., 2009. Anthropogenic soils and tree distributions in a lowland forest in Bolivia. Biotropica 41, 665-675.

Pearsall, D., 1995. Doing" paleoethnobotany in the tropical lowlands: adaptation and innovation in methodology. In: Stahl, P. (Ed.), Archaeology in the Lowland American Tropics: Current Analytical Methods and Recent Applications. Cambridge University Press, Cambridge, pp. 113-129.

Pearsall, D.M., 2008. Plant domestication and the shift to agriculture in the Andes. In: Silverman, H., Isbell, W. (Eds.), The Handbook of South American Archaeology. Springer, New York, pp. 105-120.

Pearsall, D., 2016. Palaeoethnobotany. A Handbook of Procedures, third ed. Routledge, London.

Pearsall, D.M., Chandler-Ezell, K., Zeidler, J.A., 2004. Maize in ancient Ecuador: results of residue analysis of stone tools from the Real Alto site. J. Archaeol. Sci. 31, 423-442.

Pedersen, M.W., Ginolhac, A., Orlando, L., Olsen, J., Andersen, K., Holm, J., Funder, S. Willerslev, E., Kjær, K.H., 2013. A comparative study of ancient environmental DNA to pollen and macrofossils from lake sediments reveals taxonomic overlap and additional plant taxa. Quat. Sci. Rev. 75, 161-168.

Pedersen, M.W., Overballe-Petersen, S., Ermini, L., Sarkissian, C.D., Haile, J., Hellstrom, M., Spens, J., Thomsen, P.F., Bohmann, K., Cappellini, E., 2015. Ancient and modern environmental DNA. Philos T Roy Soc B 370, 20130383.

Pedersen, M.W., Ruter, A., Schweger, C., Friebe, H., Staff, R.A., Kjeldsen, K.K., Mendoza, M.L., Beaudoin, A.B., Zutter, C., Larsen, N.K., 2016. Postglacial viability and colonization in North America's ice-free corridor. Nature 537, 45-49.

Petersen, J.B., Neves, E.G., Heckenberger, M.J., 2001. Gift from the past: terra preta and prehistoric amerindian occupation in Amazonia. In: McEwan, C., Barreto, C., Neves, E. (Eds.), Unknown Amazon: Culture in Nature in Ancient Brazil. The British Museum Press, London, pp. 86-105.

Pickersgill, B., 2007. Domestication of plants in the Americas: insights from Mendelian and molecular genetics. Ann. Bot. 100, 925-940.

Piperno, D.R., 1988. Phytolyth Analysis: an Archaeological and Geological Perspective. Academic Press, New York.

Piperno, D.R., 2006. Phytoliths: A Comprehensive Guide for Archaeologists and Paleoecologists. AltaMira Press, San Diego.

Piperno, D.R., 2011. The origins of plant cultivation and domestication in the new world tropics: patterns, process, and new developments. Curr. Anthropol. 52 S453-S470.

Piperno, D.R., Becker, P., 1996. Vegetational history of a site in the central Amazon basin derived from phytolith and charcoal records from natural soils. Quat. Res. 45, 202-209.

Piperno, D.R., Dillehay, T.D., 2008. Starch grains on human teeth reveal early broad crop diet in northern Peru. Proc. Natl. Acad. Sci. Unit. States Am. 105, 19622.

Piperno, D.R., Jones, J.G., 2003. Paleoecological and archaeological implications of a Late Pleistocene/Early Holocene record of vegetation and climate from the Pacific coastal plain of Panama. Quat. Res. 59, 79-87.

Piperno, D.R., Pearsall, D.M., 1998. The Origins of Agriculture in the Lowland Neotropics. Academic Press, San Diego.

Piperno, D.R., Stothert, K.E., 2003. Phytolith evidence for early Holocene Cucurbita domestication in southwest Ecuador. Science 299, 1054.

Piperno, D.R., Ranere, A.J., Holst, I., Hansell, P., 2000. Starch grains reveal early root crop horticulture in the Panamanian tropical forest. Nature 407, 894-897.

Piperno, D.R., Holst, I., Wessel-Beaver, L., Andres, T.C., 2002. Evidence for the control of phytolith formation in Cucurbita fruits by the hard rind $\mathrm{(Hr}$ ) genetic locus: archaeological and ecological implications. Proc. Natl. Acad. Sci. Unit. States Am. 99, 10923-10928. 
Piperno, D., Moreno, J., Iriarte, J., Holst, I., Lachniet, M., Jones, J., Ranere, A., Castanzo, R., 2007. Late pleistocene and holocene environmental history of the iguala valley, central balsas watershed of Mexico. Proc. Natl. Acad. Sci. Unit. States Am. 104, 11874-11881.

Piperno, D., Ranere, A., Holst, I., Iriarte, J., Dickau, R., 2009. Starch grain and phytolith evidence for early ninth millennium BP maize from the Central Balsas River Valley, Mexico. Proc. Natl. Acad. Sci. Unit. States Am. 106, 5019-5024.

Piperno, D.R., Ranere, A.J., Holst, I., Iriarte, J., Dickau, R., 2009b. Starch grain and phytolith evidence for early ninth millennium BP maize from the Central Balsas River Valley, Mexico. Proc. Natl. Acad. Sci. Unit. States Am. 106, 5019.

Pires de Campos, A., 1862. Breve notícia que dá o capitão Antônio Pires de Campos do gentio que há na derrota da viagem das minas do Cuyabá e seu recôncavo. Revista Trimestral do Instituto Histórico, Geográfico e Etnográfico do Brasil, 25, 4371919.

Plowman, T., 1984. The ethnobotany of coca (Erythroxylum spp., Erythroxylaceae). Adv. Econ. Bot. 1, 62-111.

Pohl, M.D., Pope, K.O., Jones, J.G., Jacob, J.S., Piperno, D.R., deFrance, S.D., Lentz, D.L., Gifford, J.A., Danforth, M.E., Josserand, J.K., 1996. Early agriculture in the Maya lowlands. Lat. Am. Antiq. 355-372.

Politis, G., 2009. Nukak: Ethnoarchaeology of an Amazonian People. Left Coast Press, Walnut Creek.

Porro, A., 1994. Social organization and political power in the Amazon floodplain: the ethnohistorical sources. In: Roosevelt, A.C. (Ed.), Amazonian Indians from Prehistory to the Present: Anthropological Perspectives. University of Arizona Press, Tucson, pp. 79-94.

Porro, A., 1996. O povo das águas: ensaios de etno-história amazônica. EdUSP.

Posey, D.A., 1985. Indigenous management of tropical forest ecosystems: the case of the Kayapo Indians of the Brazilian Amazon. Agrofor. Syst. 3, 139-158.

Prestes-Carneiro, G., Béarez, P., Shock, M.P., Prümers, H., Betancourt, C.J., 2019. PreHispanic fishing practices in interfluvial Amazonia: zooarchaeological evidence from managed landscapes on the Llanos de Mojos savanna. PloS One 14.

Prous, A., Fogaça, E., 1999. Archaeology of the pleistocene-holocene boundary in Brazil. Quat. Int. 53, 21-41.

Prümers, H., 2002. Excavaciones arqueológicas en Pailón (depto. de Sta. Cruz, Bolivia). Beiträge Allg. Vgl. Archäol. 22, 95-213.

Prümers, H., Jaimes Betancourt, C., 2014. 100 años de investigación arqueológica en los Llanos de Mojos. Arqueoantropológicas 4, 11-54.

Pugliese, F.A., Neto, C.Z., Neves, E.G., 2018. In: Smith, C. (Ed.), What Do Amazonian Shellmounds Tell Us about the Long-Term Indigenous History of South America. Encyclopedia of Global Archaeology, Springer. https://doi.org/10.1007/978-3319-51726-1 3030-2.

Quintero-Vallejo, E., Klomberg, Y., Bongers, F., Poorter, L., Toledo, M., PeñaClaros, M., 2015. Amazonian dark earth shapes the understory plant community in a Bolivian forest. Biotropica 47, 152-161.

RAISG (Amazonian Geo-referenced Socio-Environmental Information Network), 2019. Protected areas and indigenous territories. Source: https://www. amazoniasocioambiental.org/en/maps/.

Ranere, A., López, C.E., 2007. Cultural diversity in late Pleistocene/early Holocene populations in northwest South America and lower Central America. International Journal of South American Archaeology 1, 25-31.

Ranere, A.J., Cooke, R.G., Mercader, J., 2002. Late glacial and early Holocene occupation of Central American tropical forests. In: Mercader, J. (Ed.), Under the Canopy: the Archaeology of Tropical Rainforests. Rutgers University Press, New Burnswick, pp. 219-248.

Riris, P., Arroyo-Kalin, M., 2019. Widespread population decline in South America correlates with mid-Holocene climate change. Sci. Rep. 9, 6850.

Rival, L., McKey, D., 2008. Domestication and diversity in manioc (Manihot esculenta Crantz ssp. esculenta, Euphorbiaceae). Curr. Anthropol. 49, 1119-1128.

Roberts, P., 2019. Tropical Forests in Prehistory, History, and Modernity. Oxford University Press, Oxford.

Roberts, N., Fyfe, R.M., Woodbridge, J., Gaillard, M.-J., Davis, B.A., Kaplan, J.O., Marquer, L., Mazier, F., Nielsen, A.B., Sugita, S., 2018. Europe's lost forests: a pollen-based synthesis for the last 11,000 years. Sci. Rep. 8, 1-8.

Robinson, M., De Souza, J.G., Maezumi, S.Y., Cárdenas, M., Pessenda, L., Prufer, K., Corteletti, R., Scunderlick, D., Mayle, F.E., De Blasis, P., 2018. Uncoupling human and climate drivers of late Holocene vegetation change in southern Brazil. Sci. Rep. 8, 7800.

Rodrigues, L., Sprafke, T., Moyikola, C.B., Barthès, B.G., Bertrand, I., Comptour, M., Rostain, S., Yoka, J., Mckey, D., 2020. A Congo Basin ethnographic analogue of pre-Columbian Amazonian raised fields shows the ephemeral legacy of organic matter management. Sci. Rep. 10, 1-12.

Roosevelt, A.C., 1987a. Chiefdoms in the Amazon and Orinoco. In: Drennan, R.D., Uribe, C.A. (Eds.), Chiefdoms in the Americas. University Press of America, Lanham, Maryland, pp. 153-184.

Roosevelt, A.C., 1987b. Parmana: Prehistoric Maize and Manioc Subsistence along the Amazon and Orinoco. Academic Press, New York.

Roosevelt, A., 1989. Resource management in Amazonia before the conquest: beyond ethnographic projection. Adv. Econ. Bot. 7, 30-62.

Roosevelt, A.C., 1991. Moundbuilders of the Amazon: Geophysical Archaeology on Marajó Island, Brazil. Academic Press, San Diego.

Roosevelt, A.C., 2013. The Amazon and the Anthropocene: 13,000 years of human influence in a tropical rainforest. Anthropocene 4, 69-87.

Roosevelt, A.C., Housley, R.A., Da Silveira, M.I., Maranca, S., Johnson, R., 1991. Eighth millennium pottery from a prehistoric shell midden in the Brazilian Amazon. Science 254, 1621-1624.
Roosevelt, A.C., Lima da Costa, M., Lopes Machado, C., Michab, M., Mercier, N., Valladas, H., Feathers, J., Barnett, W., Imazio da Silveira, M., Henderson, A., 1996. Paleoindian cave dwellers in the Amazon: the peopling of the Americas. Science 272, 373-384.

Rostain, S., 2012. Between sierra and Selva: landscape transformations in upper Ecuadorian Amazonia. Quat. Int. 249, 31-42.

Rostain, S., Jaimes Bentancourt, C., 2017. Las siete maravillas de la Amazonía precolombina. Plural, La Paz.

Rouse, I., Cruxent, J., 1963. Venezuelan Archaeology. Yale University Press, New Haven.

Rull, V., Montoya, E., 2014. Mauritia flexuosa palm swamp communities: natural or human-made? A palynological study of the Gran Sabana region (northern South America) within a neotropical context. Quat. Sci. Rev. 99, 17-33.

Rushton, E.A., Metcalfe, S.E., Whitney, B.S., 2013. A late-Holocene vegetation history from the Maya lowlands, Lamanai, Northern Belize. Holocene 23, 485-493.

Salick, J., Cellinese, N., Knapp, S., 1997. Indigenous diversity of cassava: generation, maintenance, use and loss among the Amuesha, Peruvian Upper Amazon. Econ. Bot. 51, 6 .

Sanjur, O.I., Piperno, D.R., Andrés, T.C., Wessel-Beaver, L., 2002. Phylogenetic relationships among domesticated and wild species of Cucurbita (Cucurbitaceae) inferred from a mitochondrial gene: implications for crop plant evolution and areas of origin. Proc. Natl. Acad. Sci. Unit. States Am. 99, 535-540.

Sauer, C.O., 1944. A geographic sketch of early man in America. Geogr. Rev. 34, 529-573.

Scaldaferro, M.A., Barboza, G.E., Acosta, M.C., 2018. Evolutionary history of the chili pepper Capsicum baccatum L.(Solanaceae): domestication in south America and natural diversification in the seasonally dry tropical forests. Biol. J. Linn. Soc. $124,466-478$.

Schaan, D.P., 2012. Sacred Geographies of Ancient Amazonia: Historical Ecology of Social Complexity. Left Coast Press, Walnut Creek.

Scheel-Ybert, R., Caromano, C.F., de Azevedo, L.W., 2016. Of forests and gardens: landscape, environment, and cultural choices in Amazonia, southeastern and southern Brazil from c. 3000 to 300 cal yrs BP. Cadernos do LEPAARQ (UFPEL) 13, 425-458.

Schmidt, M.J., Heckenberger, M.J., 2009. Amerindian anthrosols: amazonian dark earth formation in the upper Xingu. In: Woods, W.I., Teixeira, W.G., Lehmann, J., Steiner, C., WinklerPrins, A.M.G.A., Rebellato, L. (Eds.), Amazonian Dark Earths: Wim Sombroek's Vision. Springer, Berlin, pp. 163-191.

Schmitz, P., Rosa, A., Bitencourt, A., 2004. Arqueologia Nos Cerrados Do Brasil Central. Serranópolis III. Instituto Anchietano de Pesquisas, São Leopoldo.

Scoles, R., Gribel, R., 2011. Population structure of Brazil nut (Bertholletia excelsa, Lecythidaceae) stands in two areas with different occupation histories in the Brazilian Amazon. Hum. Ecol. 39, 455-464.

Scott, G.J., Rosegrant, M.W., Ringler, C., 2000. Global projections for root and tuber crops to the year 2020. Food Pol. 25, 561-597.

Shepard Jr., G., Ramirez, H., 2011. "Made in Brazil": human dispersal of the Brazil nut (bertholletia excelsa, lecythidaceae) in ancient Amazonia. Econ. Bot. 65, 44-65.

Shepard Jr., G.H., Neves, E., Clement, C.R., Lima, H., Moraes, C., dos Santos, G.M. 2020. Ancient and Traditional Agriculture in South America: Tropical Lowlands. Oxford Research Encyclopedia of Environmental Science.

Shock, M.P., Moraes, C.d.P., 2019. A floresta é o domus: a importância das evidências arqueobotânicas e arqueológicas das ocupações humanas amazônicas na transição Pleistoceno/Holoceno. Boletim do Museu Paraense Emílio Goeldi. Ciências Humanas 14, 263-289.

Shock, M., de Paula Moraes, C., da Silva Belletti, J., Lima, M., da Silva, F.M., Lima, L.T. Cassino, M.F., de Lima, A.M.A., 2014. Initial contributions of charred plant remains from archaeological sites in the Amazon to reconstructions of historical ecology. In: Rostain, S. (Ed.), Antes de Orellana. Actas del 3er Encuentro Internacional de Arqueologia Amazonica. Instituto Frances de Estudios Andinos, Quito, pp. 291-304.

Sigmon, B., Vollbrecht, E., 2010. Evidence of selection at the ramosa 1 locus during maize domestication. Mol. Ecol. 19, 1296-1311.

Sillitoe, P., 2002. Always been farmer-foragers? Hunting and gathering in the Papua New Guinea Highlands. Anthropol. Forum 12, 45-76.

Silva, F.M.d., Shock, M., Neves, E.G., Lima, H.P., Scheel-Ybert, R., 2013. Recuperação de macrovestígios em sítios arqueológicos na Amazônia: nova proposta metodológica para estudos arqueobotânicos. Boletim do Museu Paraense Emílio Goeldi. Ciências Humanas 8, 759-769.

Smith, B.D., 1997. The initial domestication of Cucurbita pepo in the Americas 10,000 years ago. Science 276, 932-934

Smith, B.D., 2001. Low-level food production. J. Archaeol. Res. 9, 1-43.

Smith, M., Fausto, C., 2016. Socialidade e diversidade de pequis (Caryocar brasiliense, Caryocaraceae) entre os Kuikuro do alto rio Xingu (Brasil). Boletim do Museu Paraense Emílio Goeldi. Ciências Humanas 11, 87-113.

Smith, R.J., Mayle, F.E., 2018. Impact of mid-to late Holocene precipitation changes on vegetation across lowland tropical South America: a paleo-data synthesis. Quat. Res. 89, 134-155.

Sombroek, W., 1966. Amazon Soils: A Reconnaisance of the Soils of the Brazilian Amazon Region. Center for Agricultural Pubilications and Documentation, Wageningen.

Stahl, P.W., 2008. Animal domestication in south America. In: Silverman, H., Isbell, W. (Eds.), The Handbook of South American Archaeology. Springer, New York, pp. 121-130.

Stahl, P.W., Pearsall, D.M., 2012. Late pre-Columbian agroforestry in the tropical lowlands of western Ecuador. Quat. Int. 249, 43-52. 
Stenborg, P., Schaan, D.P., Lima, M.A., 2012. Precolumbian land use and settlement pattern in the Santarém region, lower Amazon. Amazônica 4, 222-250.

Summerhayes, G.R., Field, J.H., Shaw, B., Gaffney, D., 2017. The archaeology of forest exploitation and change in the tropics during the Pleistocene: the case of Northern Sahul (Pleistocene New Guinea). Quat. Int. 448, 14-30.

Teixeira, W.G.T., Kern, D.C., Madari, B.E., Lima, N.H., Woods, W.I., 2010. As Terras Pretas de Indio da Amazônia: Sua Caracterização e Uso deste Conhecimento na Criação de Novas Areas. Embrapa Amazônia Ocidental, Manaus.

Ter Steege, H., Pitman, N.C., Sabatier, D., Baraloto, C., Salomão, R.P., Guevara, J.E., Phillips, O.L., Castilho, C.V., Magnusson, W.E., Molino, J.-F., 2013. Hyperdominance in the Amazonian tree flora. Science 342, 1243092.

Terrell, J.E., Hart, J.P., Barut, S., Cellinese, N., Curet, A., Denham, T., Kusimba, C.M., Latinis, K., Oka, R., Palka, J., 2003. Domesticated landscapes: the subsistence ecology of plant and animal domestication. J. Archaeol. Method Theor 10, 323-368.

Thomas, E., Alcazar Caicedo, C., McMichael, C.H., Corvera, R., Loo, J., 2015. Uncovering spatial patterns in the natural and human history of Brazil nut (Bertholletia excelsa) across the Amazon Basin. J. Biogeogr. 42, 1367-1382.

van der Merwe, N.J., Roosevelt, A.C., Vogel, J.C., 1981. Isotopic evidence for prehistoric subsistence change at Parmana, Venezuela. Nature 292, 536-538.

von den Driesch, A., Hutterer, R., 2011. Mazamas, Patos criollos y anguilas de lodo. Zeitschrift für Archäologie Außereuropäischer Kulturen 4, 341-367.

Wahl, D., Byrne, R., Schreiner, T., Hansen, R., 2006. Holocene vegetation change in the northern Peten and its implications for Maya prehistory. Quat. Res. 65, 380-389.

Walker, M., Head, M.J., Berkelhammer, M., Björck, S., Cheng, H., Cwynar, L., Fisher, D., Gkinis, V., Long, A., Lowe, J., 2018. Formal ratification of the subdivision of the holocene series/epoch (quaternary system/period): two new global boundary stratotype sections and points (GSSPS) and three new stages/subseries. Episodes $41,213-223$.

Wang, X., Edwards, R.L., Auler, A.S., Cheng, H., Kong, X., Wang, Y., Cruz, F.W., Dorale, J.A., Chiang, H.-W., 2017. Hydroclimate changes across the Amazon lowlands over the past 45,000 years. Nature 541, 204-207.

Watling, J., Iriarte, J., 2013. Phytoliths from the coastal savannas of French Guiana. Quat. Int. 287, 162-180.

Watling, J., Iriarte, J., Whitney, B., Consuelo, E., Mayle, F., Castro, W., Schaan, D., Feldpausch, T., 2016. Differentiation of neotropical ecosystems by modern soil phytolith assemblages and its implications for palaeoenvironmental and archaeological reconstructions II: southwestern Amazonian forests. Rev. Palaeobot. Palynol. 226, 30-43.

Watling, J., Iriarte, J., Mayle, F.E., Schaan, D., Pessenda, L.C., Loader, N.J., StreetPerrott, F.A., Dickau, R.E., Damasceno, A., Ranzi, A., 2017. Impact of preColumbian "geoglyph" builders on Amazonian forests. Proc. Natl. Acad. Sci. Unit. States Am. 114, 1868-1873.

Watling, J., Shock, M.P., Mongeló, G.Z., Almeida, F.O., Kater, T., De Oliveira, P.E., Neves, E.G., 2018. Direct archaeological evidence for Southwestern Amazonia as an early plant domestication and food production centre. PloS One 13, e0199868.
Watling, J., Torres Castro, M., Simon, M.F., Rodrigues, F.O., Brilhante de Medeiros, M., De Oliveira, P.E., Neves, E.G., 2020a. Phytoliths from native plants and surface soils from the Upper Madeira River, and their potential for paleoecological reconstruction. Quat. Int. https://doi.org/10.1016/j.quaint.2020.03.045.

Watling, J., Almeida, F., Kater, T., Zuse, S., Shock, M.P., Mongeló, G., Bespalez, E., Santi, J.R., Neves, E.G., 2020b. Arqueobotânica das ocupações ceramistas na Cachoeira do Teotônio. Boletim do Museu Paraense Emílio Goeldi. Ciências Humanas 15, e20190075.

Weisskopf, A., Qin, L., Ding, J., Ding, P., Sun, G., Fuller, D.Q., 2015. Phytoliths and rice: from wet to dry and back again in the Neolithic Lower Yangtze. Antiquity 89, $1051-1063$.

Whitehouse, N.J., Kirleis, W., 2014. The world reshaped: practices and impacts of early agrarian societies. J. Archaeol. Sci. 51, 1-11.

Whitney, B.S., Cárdenas, M.L., 2017. Legacies of Pre-Columbian land use on Latin American ecosystem composition and diversity: a case for paleoecology. PAGES Mag 25, 84-85.

Whitney, B.S., Rushton, E.A., Carson, J.F., Iriarte, J., Mayle, F.E., 2012. An improved methodology for the recovery of Zea mays and other large crop pollen, with implications for environmental archaeology in the Neotropics. Holocene 22, 1087-1096.

Whitney, B.S., Dickau, R., Mayle, F.E., Soto, J.D., Iriarte, J., 2013. Pre-Columbian landscape impact and agriculture in the Monumental Mound region of the 'Llanos de Moxos', lowland Bolivia. Quat. Res. 80, 207-217.

Whitney, B.S., Dickau, R., Mayle, F.E., Walker, J.H., Soto, J.D., Iriarte, J., 2014. PreColumbian raised field agriculture and land use in the Bolivian Amazon. Holocene 24, 231-241.

Whitney, B.S., Smallman, T.L., Mitchard, E.T., Carson, J.F., Mayle, F.E., Bunting, M.J., 2019. Constraining pollen-based estimates of forest cover in the Amazon: a simulation approach. Holocene 29, 262-270.

Willcox, G., 2012. Searching for the origins of arable weeds in the Near East. Veg. Hist. Archaeobotany 21, 163-167.

Woods, W., 2009. Os solos e as ciências humanas: interpretação do passado. In: Teixeira, W.G., Kern, D.C., Madari, B.E., Lima, H., Woods, W.I. (Eds.), As Terras Pretas de Índio da Amazônia: sua caracterização e uso deste conhecimento na criação de novas áreas. Embrapa Amazonia Ocidental, Manaus, pp. 62-71.

Woods, W.I., McCann, J.M., 1999. The anthropogenic origin and persistence of Amazonian dark earths, Yearbook. In: Conference of Latin Americanist Geographers. University of Texas Pres, Austin, pp. 7-14.

Woods, W.I., Teixeira, W.G., Lehmann, J., Steiner, C., WinklerPrins, A.M.G.A., Rebellato, L., 2009. Amazonian Dark Earths: Wim Sombroek's Vision. Springer, Berlin.

Zarrillo, S., 2012. Human Adaptation. Food Production. and Cultural Interaction during the Formative Period in Highland Ecuador. University of Calgary.

Zarrillo, S., Gaikwad, N., Lanaud, C., Powis, T., Viot, C., Lesur, I., Fouet, O., Argout, X., Guichoux, E., Salin, F., 2018. The use and domestication of Theobroma cacao during the mid-Holocene in the upper Amazon. Nature ecology \& Evolution 2, 1879-1888. 